San Jose State University

SJSU ScholarWorks

Master's Theses

Master's Theses and Graduate Research

Spring 2015

\title{
Growth, mortality, and reproductive potential of California Halibut (Paralichthys californicus) off central California
}

Cheryl L. Barnes

San Jose State University

Follow this and additional works at: https://scholarworks.sjsu.edu/etd_theses

\section{Recommended Citation}

Barnes, Cheryl L., "Growth, mortality, and reproductive potential of California Halibut (Paralichthys californicus) off central California" (2015). Master's Theses. 4527.

DOI: https://doi.org/10.31979/etd.wd2a-vj4j

https://scholarworks.sjsu.edu/etd_theses/4527

This Thesis is brought to you for free and open access by the Master's Theses and Graduate Research at SJSU ScholarWorks. It has been accepted for inclusion in Master's Theses by an authorized administrator of SJSU ScholarWorks. For more information, please contact scholarworks@sjsu.edu. 


\author{
A Thesis \\ Presented to \\ The Faculty of the Department of Marine Science \\ San José State University \\ In Partial Fulfillment \\ of the Requirements for the Degree \\ Master of Science
}

by

Cheryl L. Barnes

June 2015 
(C) 2015

Cheryl L. Barnes

ALL RIGHTS RESERVED 
The Designated Thesis Committee Approves the Thesis Titled

GROWTH, MORTALITY, AND REPRODUCTIVE POTENTIAL OF CALIFORNIA HALIBUT (PARALICHTHYS CALIFORNICUS) OFF CENTRAL CALIFORNIA

by

Cheryl L. Barnes

APPROVED FOR MOSS LANDING MARINE LABORATORIES

SAN JOSÉ STATE UNIVERSITY

June 2015

Dr. Richard M. Starr

Dr. James T. Harvey

Dr. Scott L. Hamilton

Paul N. Reilly
Moss Landing Marine Laboratories

Moss Landing Marine Laboratories

Moss Landing Marine Laboratories

California Department of Fish and Wildlife 


\section{ABSTRACT \\ GROWTH, MORTALITY, AND REPRODUCTIVE POTENTIAL OF CALIFORNIA HALIBUT (PARALICHTHYS CALIFORNICUS) OFF CENTRAL CALIFORNIA

\author{
by Cheryl L. Barnes
}

Differences in key biological processes, such as growth and reproduction, can greatly influence localized population dynamics. Thus, it is important to evaluate intraspecific variation at several spatial scales to better understand biological limitations and develop management plans that maximize fishery sustainability. In 2011, the California Department of Fish and Wildlife (CDFW) conducted its first comprehensive stock assessment for California Halibut, Paralichthys californicus. However, limited life history data were available north of Point Conception. To improve our understanding of central California Halibut biology, 704 fish were collected during 2012 and 2013. Von Bertalanffy growth parameters were estimated at $\mathrm{L}_{\infty}=1041 \mathrm{~mm}$ and $\mathrm{K}=0.25$ for females and $\mathrm{L}_{\infty}=824 \mathrm{~mm}$ and $\mathrm{K}=0.22$ for males. Catch curve analysis indicated total mortality at 0.32 for females and 0.47 for males. Incidence of spawning females was used to estimate a seasonal spawning duration of $79 \mathrm{~d}$, and temporal variation in gonadosomatic index identified peak spawning activity in July. The gravimetric method was used to estimate batch fecundity for an average-sized female $(850 \mathrm{~mm})$ at $6.0 \times 10^{5}$ eggs $\pm 6.7 \times 10^{4}(\mathrm{SE})$. Batch fecundity was multiplied by a spawning frequency of 25 to approximate seasonal fecundity at $1.4 \times 10^{7}$ eggs $\pm 1.3 \times 10^{6}(\mathrm{SE})$. When possible, comparisons were made with southern California Halibut using CDFW-collected data or results from the scientific literature. The information presented enhances our knowledge of California Halibut life history and provides region-specific estimates for future stock assessments. 


\section{ACKNOWLEDGMENTS}

Financial and logistical support for this study was provided by Moss Landing Marine Laboratories, San José State University (SJSU), California Department of Fish and Wildlife, California Sea Grant Extension Program, CSU Council on Ocean Affairs, Science, and Technology, Michael Lee Environmental Foundation, Dr. Earl H. Myers and Ethel M. Myers Oceanographic and Marine Biology Trust, and the David \& Lucille Packard Foundation.

The results presented herein are the culmination of efforts from many people across California. This project would not have been possible without the support of countless recreational anglers, commercial hook-and-line fishermen, spear divers, and local seafood processors. Thank you for taking the time to speak with me about my project, put forth effort to better understand the research objectives, and graciously donate portions of your catch for science! My sincere appreciation goes out to the men and women of Capitola Boat and Bait (especially Ed Burrell) and H\&H Fresh Fish, who provided the majority of specimens used in this study. Your enthusiasm, patience, and permittance for me to disrupt the natural order of business have not gone unnoticed.

Additionally, I would like to thank David 'Shorty' Reins (captain, FV Caroline) for allowing me (and my volunteers) to participate in a number of halibut fishing trips during the summer of 2013.

This study would not have accomplished what it had without the help of many dedicated volunteers. Field interns, Alexandra Aines, Daniel Anaya, Caitrin Doles, Rhiannon McCollough, and Elizabeth Schurig spent every 
weekend during the summer of 2013 scouring wharfs, harbors, and cleaning tables for potential carcass donations from the fishing community. Laboratory interns Kaitlin Beck, Adam Chorazyczewski, Christopher Giordano, Hallie Heath, Serena Lomonico, Nicole Siababa, and Aaron Sloan spent countless hours sampling ovaries, separating eggs, scanning microscope slides, organizing samples, preparing otoliths, entering and checking data...the list goes on! Nikki, Adam, and Kaitie: I am especially indebted to you for working longer hours and many more months than anticipated in order to help this graduate student finish up. Your dedication is admirable.

The assistance provided by CDFW staff was also essential to this work. Brian Owens was extremely helpful throughout the permitting process. Jayna Schaaf-Da Silva and the California Recreational Fisheries Survey (CRFS) samplers helped collect specimens in each of the five sampling locations (special thanks to CRFS sampler, Kenji Soto). Paul Reilly, Travis Tanaka, Dave Osorio, Matt Michie, Ken Oda, and a number of other CDFW staff helped muscle in an absurd number of beach seines in an attempt to catch the oh-soillusive sublegal halibut.

Paul Reilly (CDFW Senior Environmental Scientist) and Travis Tanaka (CDFW Environmental Scientist) played an integral role in shaping my thesis by making the ageing components possible. Paul Reilly served as the second, more experienced reader for all otoliths. Travis Tanaka provided substantial support by helping to prepare nearly 500 otoliths and serving as the "dispute settler" when Paul and I disagreed on final ages for a particular fish. CDFW 
volunteers Dario Caloss, Roger Williams, Richard White, and Richard Locattelli assisted in thin section preparations. Regional comparisons of growth and mortality were made possible by CDFW-collected length and age data for southern California Halibut (special thanks to Kim Penttila, Adrienne Vincent, and Kyle Evans) as well as supplementary data collected north of Point Conception. Additionally, Kristine Lesyna (CDFW Environmental Scientist) and I worked very closely to develop a maturity staging system for California Halibut in order to categorize fish both macroscopically and via histology. Without this partnership and additional support from CDFW, I would not have been able to process and analyze my samples histologically.

Paul Reilly, Travis Tanaka, and Kristine Lesyna...I sincerely appreciate all of your support and constant encouragement. You've been such a pleasure to work with and I am glad that we have become friends in addition to colleagues through the help of our favorite flatfish! I will take with me so many things that I have learned from each of you, hope that I returned the favor and teach you a few things, and look forward to working with you again in the future.

Along with the considerable help that I received from CDFW personnel, I greatly benefitted from the support of countless individuals at my home institution, Moss Landing Marine Laboratories (MLML). MLML facilities staff were instrumental in designing field and laboratory tools used in data collection. Thank you for welcoming my regular interruptions and odd requests. I would also like to thank the office staff for their continual assistance with processing paperwork and answering procedural questions. To the MLML faculty who 
helped shape my educational experience, through varied coursework and inspiring conversations, I am indebted to you as well. As for MLML's Ichthyology and Fisheries \& Conservation Biology labs, thank you for your flexibility, shared use of laboratory space and equipment, and constructive critiques throughout this process.

Many thanks go out to the members of my thesis committee: Rick Starr, Scott Hamilton, Jim Harvey, and Paul Reilly. Your guidance and support throughout the development, implementation, analyses, and presentation of my thesis research were invaluable. I greatly appreciate each and every one of you for challenging me to produce the highest quality work possible. Rick, thank you so much for helping me attain my academic goals while providing countless opportunities for professional development. I truly benefitted from working by your side, in your lab, and as part of California Sea Grant for almost five years.

Finally, to my friends and family: thank you for supporting my aspirations, even though you may not have completely understood them. Jennifer Chatham, thank you for listening to me talk about California Halibut and fisheries science for more hours that either of us care to admit. Grant Waltz and Nancy Brown, thank you for graciously providing your support, friendship, and a comfortable home for me during remote sampling efforts. You made my regular trips to Morro Bay and Port San Luis much more enjoyable than I could have imagined. And for those of you who were directly involved in carcass pickups when I was unable to do so myself, I greatly appreciate your willingness to get a little sticky for the good of the cause. Your data points are in there! 


\section{TABLE OF CONTENTS}

LIST OF TABLES

LIST OF FIGURES

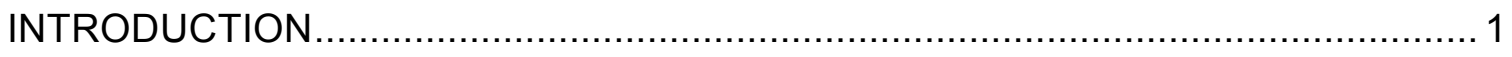

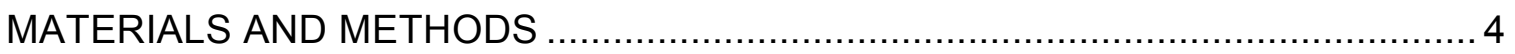

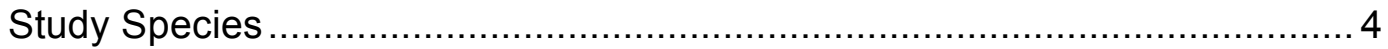

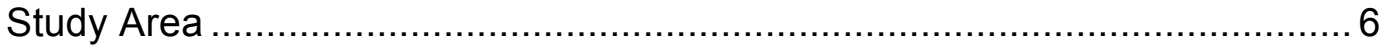

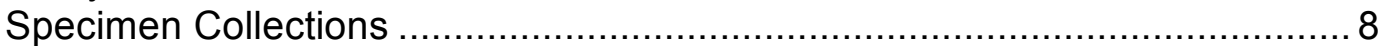

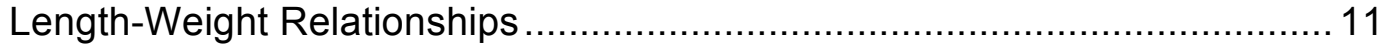

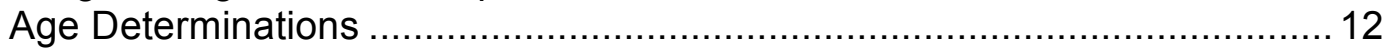

Assessing Rates of Growth ..................................................................... 14

Estimating Total Mortality ……........................................................ 16

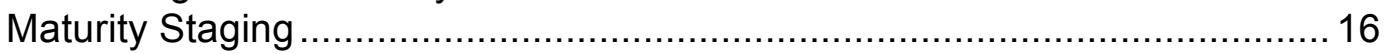

Characterization of the Spawning Season................................................ 19

Daily Spawning Fraction, Interspawning Interval, Spawning Frequency ....... 20

Batch Fecundity …….................................................................... 21

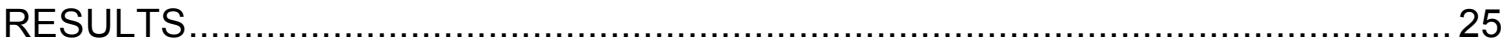

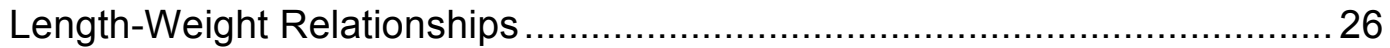

Reader Agreement in Ageing California Halibut ...................................... 30

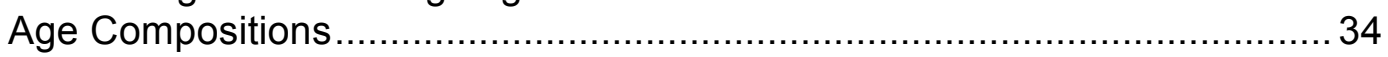

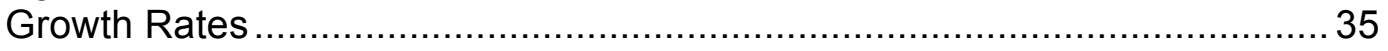

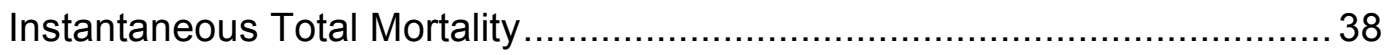

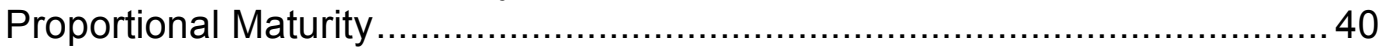

Characterization of the Summer Spawning Season .................................. 42

Daily Spawning Fraction, Interspawning Interval, Spawning Frequency ....... 46

Batch Fecundity …….................................................................. 47

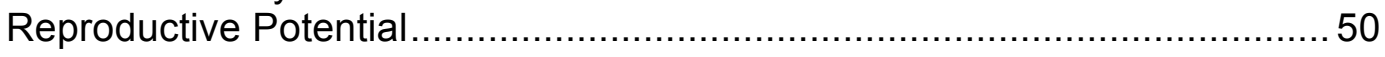

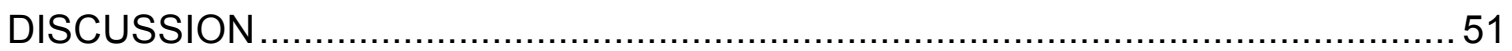

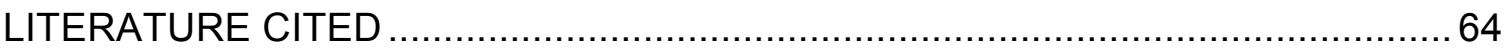

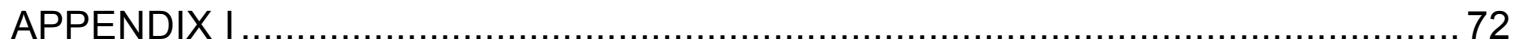

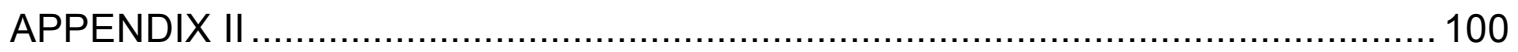




\section{LIST OF TABLES}

1. Number of specimens collected, by sex and sampling location. Fish listed as central California were caught in San Francisco Bay, Half Moon Bay, or an undetermined location within Monterey Bay.

2. Number of specimens collected, by fishery and gear type. Three additional fish were collected using fishery-independent methods

3. Minimum, mean (standard deviation), and maximum fork lengths $(\mathrm{mm})$ for central California Halibut, by sex. Sample sizes $(n)$ are indicated....

4. Minimum, mean (standard deviation), and maximum wet body weights (g)

for central California Halibut, by sex. Sample sizes $(n)$ are indicated 30

5. Minimum, mean (standard deviation), and maximum ages ( $\mathrm{yr}$ ) for central California Halibut, by sex. Sample sizes $(n)$ are indicated

6. Von Bertalanffy growth parameters $L_{\infty}$ and $\mathrm{K}$ for California Halibut (Barnes and CDFW data), by sex and region. Standard errors are shown in parentheses....

7. Simplified maturity staging system for female California Halibut, Paralichthys californicus. The microscopic terms used are consistent with Murua et al. (2003). MAS: most advanced stage of oocyte development.

8. Summary of reproductive parameters for female California Halibut, by year. Sample size $(n)$ indicates the number of days used in each calculation ( $\geq 3$ reproductively active females were required for inclusion) 46

9. Parameters used to calculate seasonal reproductive potential of an average-sized central California Halibut female 


\section{LIST OF FIGURES}

1. Mean larval density (no. of California Halibut per $10 \mathrm{~m}^{2}$, wet displacement volume) by month. Error bars represent one standard error.

Ichthyoplankton data were collected between 0 and $185 \mathrm{~m}$ water depth, from Point Conception (US) to Baja California (MX) (CalCOFI, 1980 to 2011). Closed circles and solid lines indicate southern California transects, whereas open circles and dashed lines denote data collected off of the Mexican coast. Data from central California are not illustrated due to relatively offshore transects and infrequent surveys

2. Locations used to sample California Halibut, Paralichthys californicus, in central California.

3. Bimonthly mean landings of California Halibut caught between San Francisco Bay and Morro Bay, CA from 2004 to 2013 (CDFW unpublished data). The solid line represents recreational landings (no. fish) and the dashed line denotes commercial landings (1000s lb). Errors bars indicate one standard error

4. Diagram of fork length measurement. California Halibut, Paralichthys californicus, drawing by (C) Larry G. Allen.....

5. Thin-sectioned sagittal otoliths from two California Halibut, both aged at $8 \mathrm{yr}$ (upper: blind-side otolith, lower: eyed-side otolith). The combination of one opaque and one adjacent, translucent zone represents a single year of growth. White circles (upper image) indicate individual annuli

6. Histological slide of spawning California Halibut ovary indicating various stages of oocyte development used in maturity stage classifications. PV: pre-vitellogenic (i.e., chromatin nuclear, perinucleolar); CA: cortical alveoli; YG: yolk granule; FM: final maturation; HD: hydrated; POF: postovulatory follicle.

7. Histological slide of spent (left) and spawning (right) California Halibut ovaries indicating various stages of oocyte development used in maturity stage classifications. HD: hydrated; POF-0: postovulatory follicle theoretically formed on the day of capture; POF-1: postovulatory follicle theoretically formed one day before capture; aAT: alpha (primary stage) atresia; bAT: beta (secondary stage) atresia.

8. Whole mount image of California Halibut oocytes. Hydrated oocytes (HD) are distinguishable from less developed stages due to their larger size, greater transparency, wrinkled appearance, and obvious oil globule (OG)...... 22 


\section{LIST OF FIGURES (Continued)}

9. Relationship between pre- and post-fillet fork length $(\mathrm{mm})$ measurements for California Halibut $(n=152)$. Black circles denote females and gray squares denote males. The black dashed line indicates the predicted postfillet fork length $(\mathrm{mm})$ at any particular pre-fillet fork length $(\mathrm{mm})$, given the equation $y=1.01 x-0.94\left(R^{2}=0.999, F_{1,150}=279210, p<0.001\right)$.

10. Length frequency distributions for central California Halibut, by sex. Black bars indicate females and gray bars indicate males

11. Relationship between fork length $(\mathrm{mm})$ and wet body weight $(\mathrm{g})$ for California Halibut caught off of central California. Black circles represent females and gray squares represent males. The dashed lines with corresponding colors indicate the predicted weight $(\mathrm{g})$ at length $(\mathrm{mm})$

12. Mean ages (yr) for Reader 2, as compared with ages (yr) determined by Reader $1(n=457)$. Error bars represent one standard error above and below the mean. The dashed line indicates a theoretical one-to-one relationship

13. Mean ages (yr) for Reader 3, as compared to ages (yr) determined by Reader $1(n=224)$. Error bars represent one standard error above and below the mean. The dashed line indicates a theoretical one-to-one relationship

14. Mean ages (yr) for Reader 3, as compared to ages ( $y r$ ) determined by Reader $2(n=224)$. Error bars represent one standard error above and below the mean. The dashed line indicates a theoretical one-to-one relationship

15. Proportional agreement between Reader 1 and Reader 2, by age (yr). The dashed line represents the best-fit linear relationship between age and proportional agreement $\left(y=-0.05 x+0.92 ; R^{2}=0.871, p<0.001, n=457\right) \ldots 33$

16. Age frequency distributions for central California Halibut, by sex. Black bars indicate females and gray bars indicate males

17. Length $(\mathrm{mm})$ at age $(\mathrm{yr})$ data for central California Halibut, by sex (Barnes data). Black circles denote females and gray squares denote males. Solid lines indicate predicted length-at-age, given the von Bertalanffy growth equations $L_{t}=1041\left(1-e^{-0.22(t+0)}\right)$ for females and $L_{t}=824\left(1-e^{-0.25(t+0)}\right)$ for males 


\section{LIST OF FIGURES (Continued)}

18. Von Bertalanffy growth parameters $\mathrm{K}$ and $\mathrm{L}_{\infty}$ (Barnes data), denoted by asterisks. Ellipses indicate the $95 \%$ confidence intervals for female (black) and male (gray) California Halibut collected north of Point Conception

19. Von Bertalanffy growth curves for central (solid lines) and southern (dashed lines) California Halibut (Barnes and CDFW data). Expected lengths $(\mathrm{mm})$ at age $(\mathrm{yr})$ are shown in black for females and gray for males ... 37

20. Von Bertalanffy growth parameters $K$ and $L_{\infty}$, illustrated by asterisks (Barnes and CDFW data). Ellipses denote the 95\% confidence intervals. Females are shown in black (left) and males are shown in gray (right). Solid ellipses indicate central California Halibut and dashed ellipses indicate southern California Halibut

21. Instantaneous total mortality for central California Halibut caught in 2013 (Barnes data), given log-linear frequencies of age classes $\geq 8 \mathrm{yr}$. Female total mortality is represented by the equation $y=5.93-0.32 x\left(R^{2}=0.617\right.$, $p=0.012)$ and male total mortality is represented by $y=6.83-0.47 x$ $\left(R^{2}=0.710, p=0.035\right)$

22. Instantaneous total mortality for California Halibut, Paralichthys californicus. Fish collected from central California in 2013 (Barnes and CDFW data) are represented by solid lines and fish collected from southern California in 2012 (CDFW data) are represented by dashed lines. Females are shown in black and males are shown in gray

23. Proportions of females sampled in central California (2013), by microscopic maturity stage and month. Sample sizes are indicated above each bar, which represents a $14 \mathrm{~d}$ sampling period. * = one mature fish sampled; ** $=$ two maturing fish sampled

24. Mean gonadosomatic index for female California Halibut caught in central California (2013), by week and maturity stage. Error bars denote one standard error....

25. Mean hepatosomatic index for female California Halibut caught in central California (2013), by week and maturity stage. Error bars denote one standard error..... 


\section{LIST OF FIGURES (Continued)}

26. Maturation cycle of a California Halibut female throughout a given spawning season [based upon gonadosomatic index (GSI), batch fecundity (millions of oocytes), and interspawning interval (i.e., elapsed time from spawning in days)]. Dashed circles illustrate hypothetical sampling events, with the ideal capture time located at peak values. Figure adapted from Hunter et al. (1985).

27. Relationship between fork length $(\mathrm{mm})$ and batch fecundity (thousands of eggs) for female California Halibut in the late hydration phase of spawning (i.e., presence of hydrated oocytes, no final maturation stage or new post ovulatory follicles). The dashed line indicates the expected batch fecundity at length $(n=17)$.....

28. Batch fecundity (thousands of hydrated oocytes) of California Halibut, by Julian day (2013). Circles represent estimates for spawning females in the late hydration (i.e., presence of hydrated oocytes, no final maturation stage or new postovulatory follicles) or actively spawning (i.e., presence of hydrated oocytes and new postovulatory follicles) phases $(n=33)$. The dashed line indicates the expected batch fecundity at length, given the equation $\mathrm{F}=-8.3 \times 10^{7}+1.6 \times 10^{6} \mathrm{~L}-84.1 \mathrm{~L}^{3}$ 


\section{INTRODUCTION}

Due to financial and logistical limitations, the information used in stock assessments is often collected and analyzed at broad (e.g., state-wide, nation-wide) spatial scales. Although averaging the condition of a species across its range simplifies management, fine-scale (e.g., regional) variation in life history characteristics can result in localized over- or under-utilization of the resource (Prince 2010). Without spatially relevant data to account for this variation, we cannot fully understand how populations (or stocks) are differentially affected by fishing pressure (Levins 1969; Adams 1980; Orensanz et al. 2005; Pascoe et al. 2009; Caselle et al. 2011). Thus, evaluating intraspecific variation at several spatial scales provides a better understanding of the biological limitations of economically important species and promotes the development of fishery management strategies that are effective at balancing harvest and conservation throughout a species' range (Clark 1930). This is especially applicable for species with widespread distributions that span distinct biogeographic boundaries (Hedgecock 1994; Somero 2005; Leis 2007; Cope and Punt 2011).

California Halibut, Paralichthys californicus (family Paralichthyidae), is an economically important species that exhibits a relatively widespread distribution, spanning Point Conception, which serves as a boundary between two well-known biogeographic regions. The fishery for California Halibut began in the mid-1910s as bycatch from fishing trips targeting rockfishes, Sebastes spp. (Kramer et al. 2001). Commercial landings peaked at $1500 \mathrm{t}$ in 1919 , whereas recreational landings peaked at 1.2 million fish in 1964. Since 1980, California Halibut landings have 
fluctuated around $400 \mathrm{t}$ for commercial fisheries and 0.2 million fish for recreational fisheries (Maunder et al. 2011). Due to rapid declines in catch during the latter half of the twentieth century, numerous regulations were placed upon the California Halibut fishery (Allen 1988; CDFG 2011a). Recreational bag limits of three fish per day in central California and five fish per day in southern California were introduced in 1971 to maintain adequate population sizes necessary for stock replenishment. A minimum size limit of 22 inches $(559 \mathrm{~mm})$, designed to prevent the harvest of immature individuals, also was established during the 1970s. Finally, variations in gear regulations for bottom trawls and spatial restrictions on gill net use were instituted during the past 60 years to limit take of juvenile California Halibut and nontarget species.

In 2011, the California Department of Fish and Game (CDFG, now known as the California Department of Fish and Wildlife, CDFW) conducted its first comprehensive stock assessment for California Halibut to determine population size and the effectiveness of existing management actions (Maunder et al. 2011). As part of this assessment, fishery-independent and fishery-dependent data were synthesized and incorporated into statistical models developed for two separate stocks, north and south of Point Conception. Although large amounts of biological information were made available during the assessment, life history data pertained primarily to halibut from southern California (e.g., Allen 1988; Allen and Herbinson 1990; Allen et al. 1990; Kramer 1990; Domeier and Chun 1995; Valle et al. 1998; MacNair et al. 2001). The informational void for central California Halibut forced stock assessment scientists to base initial model parameters (e.g., natural mortality, 
mean length assumed for the oldest fish) on values obtained from the southern California population. Maunder et al. (2011) noted that the central California stock model was "very sensitive to initial parameters...[and] that the values for these parameters determined by the model fitting procedure may not be reliable." This prompted resource managers to prioritize the collection of sex-specific age, growth, reproduction, and mortality data for California Halibut found north of Point Conception (CDFG 2011b).

To meet the needs of management and enhance our understanding of the biology and ecology of an economically important species, I assessed age, growth, total mortality, and reproductive potential of California Halibut collected north of Point Conception (referred to as "central California Halibut" forward-going). Specifically, I collected length-at-age data, calculated sex-specific von Bertalanffy growth parameters, and used catch curve analysis to approximate total mortality. I also estimated the duration of the summer spawning season, spawning frequency, and batch fecundity to describe the reproductive potential of central California Halibut. Additional CDFW-collected data from both central and southern California were analyzed to make regional comparisons of growth and mortality, enhancing our understanding of spatiotemporal variation in California Halibut life history. 


\section{MATERIALS AND METHODS}

\section{Study Species}

California Halibut can be found as far north as the Quillayute River in Washington and as far south as Magdalena Bay, Baja California Sur, Mexico (Miller and Lea 1972). However, relatively few individuals are encountered north of Bodega Bay in central California. Throughout their range, California Halibut frequently conceal themselves in sandy bottoms adjacent to hard substrate or biogenic habitats (e.g., giant kelp, Macrocystis pyrifera, or sand dollar, Dendraster excentricus, beds) to evade predators and ambush prey (Feder et al. 1974; Allen 1988). California Halibut feed primarily on small invertebrates (e.g., polychaetes, amphipods, crabs) as juveniles and become increasingly piscivorous with age (Allen 1988). As adults, California Halibut typically prey upon small fishes [e.g., Northern Anchovy (Engraulis mordax), Pacific Sardine (Sardinops sagax), California Grunion (Leuresthes tenuis)] and cephalopods [e.g., Market Squid (Doryteuthis opalescens) and Octopus spp.] (Frey 1971).

Located to depths of $185 \mathrm{~m}$, adult California Halibut from southern California move into shallower waters (e.g., 6 to $20 \mathrm{~m}$ ) during the spring (Clark 1930). Some of the greatest larval densities in southern California coincide with these shallow water migrations in both time and space, indicating that inshore-offshore migrations may be related to spawning activity (Clark 1930; Lavenberg et al. 1986; CalCOFI 2014) (fig. 1). A second peak in larval densities occurs in Mexico in June and in southern California in July, demonstrating increased reproductive effort in spring and summer. In laboratory experiments conducted under natural conditions, southern California 
Halibut spawned at water temperatures between 15.0 and $16.5^{\circ} \mathrm{C}$ and on day lengths greater than $10.5 \mathrm{hr}$ (Caddell et al. 1990). Additionally, captive females from this laboratory study broadcasted approximately 589,000 eggs every $14 \mathrm{~d}$ for approximately $182 \mathrm{~d}$ (April through September), indicating a heterochronal (i.e., multiple spawning) mode of reproduction.

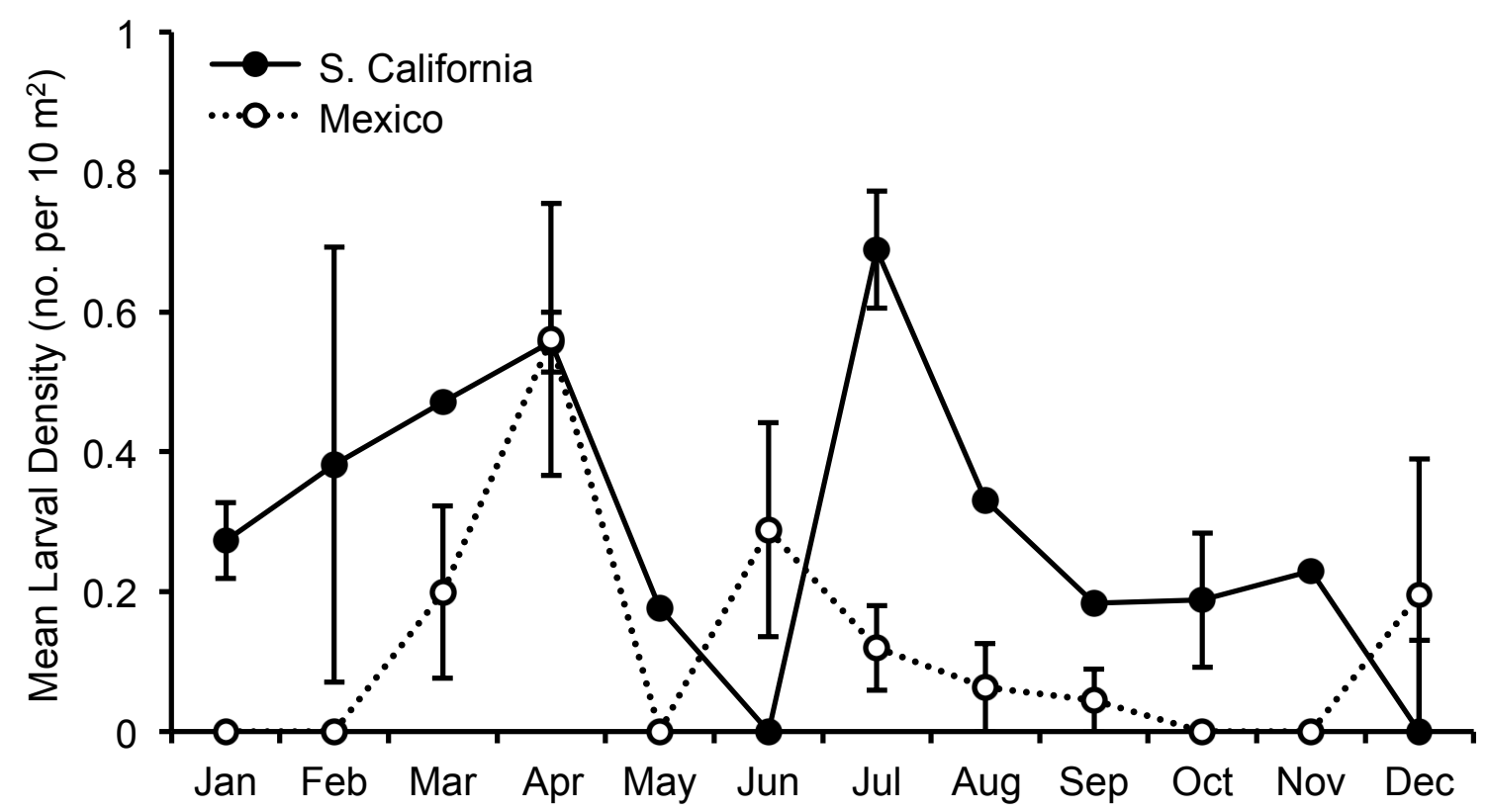

Figure 1. Mean larval density (no. of California Halibut per $10 \mathrm{~m}^{2}$, wet displacement volume) by month. Error bars represent one standard error. Ichthyoplankton data were collected between 0 and $185 \mathrm{~m}$ water depth, from Point Conception (US) to Baja California (MX) (CalCOFI, 1980 to 2011). Closed circles and solid lines indicate southern California transects, whereas open circles and dashed lines denote data collected off of the Mexican coast. Data from central California are not illustrated due to relatively offshore transects and infrequent surveys.

Once hatched, California Halibut experience a relatively short larval duration (Allen 1988). In 20 to $29 \mathrm{~d}$, nearshore pelagic larvae undergo metamorphosis as one eye migrates to the opposite side of the head and swimming behavior transitions from upright to lateralized. When metamorphosis is complete, larvae of approximately $17 \mathrm{~mm}$ (standard length) settle into benthic habitats of shallow-water 
embayments (Kramer 1990). Juveniles, ranging from 140 to $220 \mathrm{~mm}$ (standard length), emigrate to the open coast as they begin to mature (Allen 1988; Kramer 1991). Male halibut from southern California have been documented as first reaching sexual maturity at $19 \mathrm{~cm}(1 \mathrm{yr})$, whereas females from the same region do not mature until at least $36 \mathrm{~cm} \mathrm{(2} \mathrm{yr)} \mathrm{(Love} \mathrm{and} \mathrm{Brooks} \mathrm{1990).} \mathrm{At} \mathrm{the} \mathrm{population}$ level, $50 \%$ of males are considered mature at $23 \mathrm{~cm}(1.3 \mathrm{yr})$ and $50 \%$ of females are

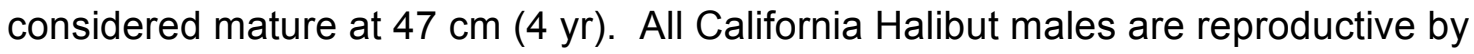
$32 \mathrm{~cm}(3 \mathrm{yr})$ and all females are reproductive by $59 \mathrm{~cm}(7 \mathrm{yr})$.

MacNair et al. (2001) suggested that southern California Halibut enter the fishery [i.e., reach the minimum legal size limit of 22 inches $(559 \mathrm{~mm})$ fork length] at approximately $5.4 \mathrm{yr}$ for males and $9.4 \mathrm{yr}$ for females, whereas central California Halibut attain harvestable sizes at 4.6 for males and $6.7 \mathrm{yr}$ for females, indicating faster growth in central California. The historical maximum length, weight, and age of California Halibut are $152 \mathrm{~cm}, 32.7 \mathrm{~kg}$, and $30 \mathrm{yr}$ (Frey 1971; Eschmeyer et al. 1983). However, recent maxima for this species have been recorded as $130 \mathrm{~cm}$, $30.4 \mathrm{~kg}$, and $23 \mathrm{yr}$ (CDFW data, 2007 to 2014).

\section{Study Area}

California Halibut were collected from shallow $(<40 \mathrm{~m})$, coastal waters near five central California locations: Santa Cruz ( $\left.36^{\circ} 57^{\prime} \mathrm{N},-122^{\circ} 00^{\prime} \mathrm{W}\right)$, Moss Landing $\left(36^{\circ} 48^{\prime} \mathrm{N},-121^{\circ} 47^{\prime} \mathrm{W}\right)$, Monterey $\left(36^{\circ} 18^{\prime} \mathrm{N},-121^{\circ} 53^{\prime} \mathrm{W}\right)$, Morro Bay $\left(35^{\circ} 22^{\prime} \mathrm{N}\right.$, $\left.-120^{\circ} 51^{\prime} \mathrm{W}\right)$, and Port San Luis ( $\left.35^{\circ} 10^{\prime} \mathrm{N},-120^{\circ} 45 \mathrm{~W}\right)$ (fig. 2). A small number of fish were opportunistically collected near San Francisco Bay and Half Moon Bay, CA as well. The nearshore environments at all of these sites consist of benthic habitats 
that are mixed sand and rock or entirely soft bottom, and are known to accommodate California Halibut. Each of the selected sites also encompasses at least one wharf or harbor that serves as a homeport for fishers actively targeting the species. Finally, collection sites spanned the central California coast to enable characterization of life history traits at the regional spatial scale. Efforts to collect fish from San Francisco Bay were not made because a comparable, CDFW-led study was being conducted in that location during the same time period.

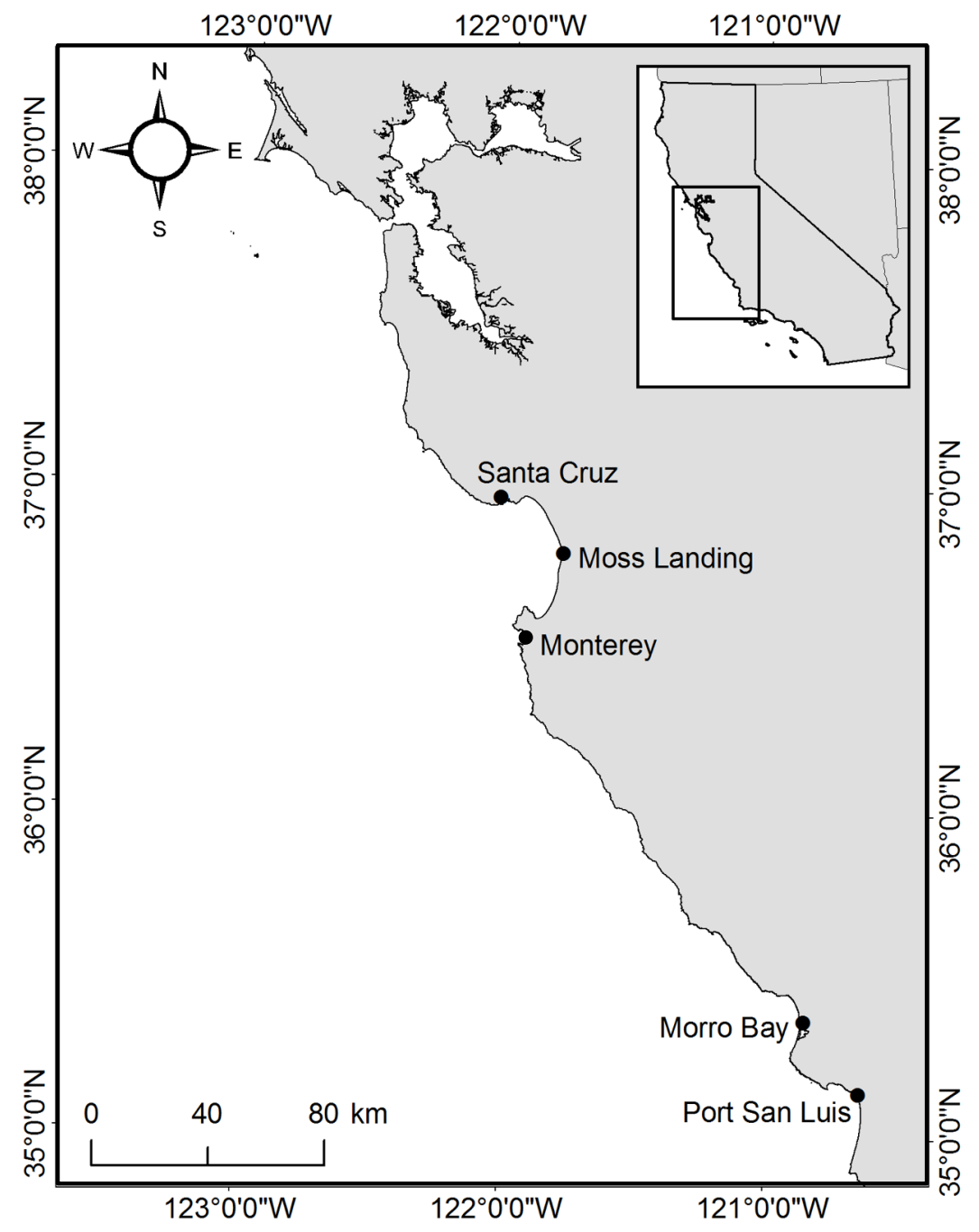

Figure 2. Locations used to sample California Halibut, Paralichthys californicus, in central California. 


\section{Specimen Collections}

Collection efforts were concentrated during the summer months (i.e., end of May to mid September) of 2012 and 2013, when the greatest quantities of halibut are caught in central California (fig 3) (CDFW unpublished data). A variety of gear types (i.e., hook-and-line, spear, beach seine, trawl) were used to capture fish. In an effort to collect sublegal fish, I conducted six, 10-min otter trawl tows offshore of Moss Landing, CA. CDFW staff and I also attempted to catch fish at Del Monte Beach (Monterey, CA) using a 125-ft beach seine one to two days per month from May to September, 2013. However, these combined efforts resulted in only one 394 $\mathrm{mm}$ female California Halibut caught via beach seine. Consequently, the majority of samples were collected as carcasses donated from recreational fishers and seafood processors and, thus, were above the legal size limit $(559 \mathrm{~mm})$.

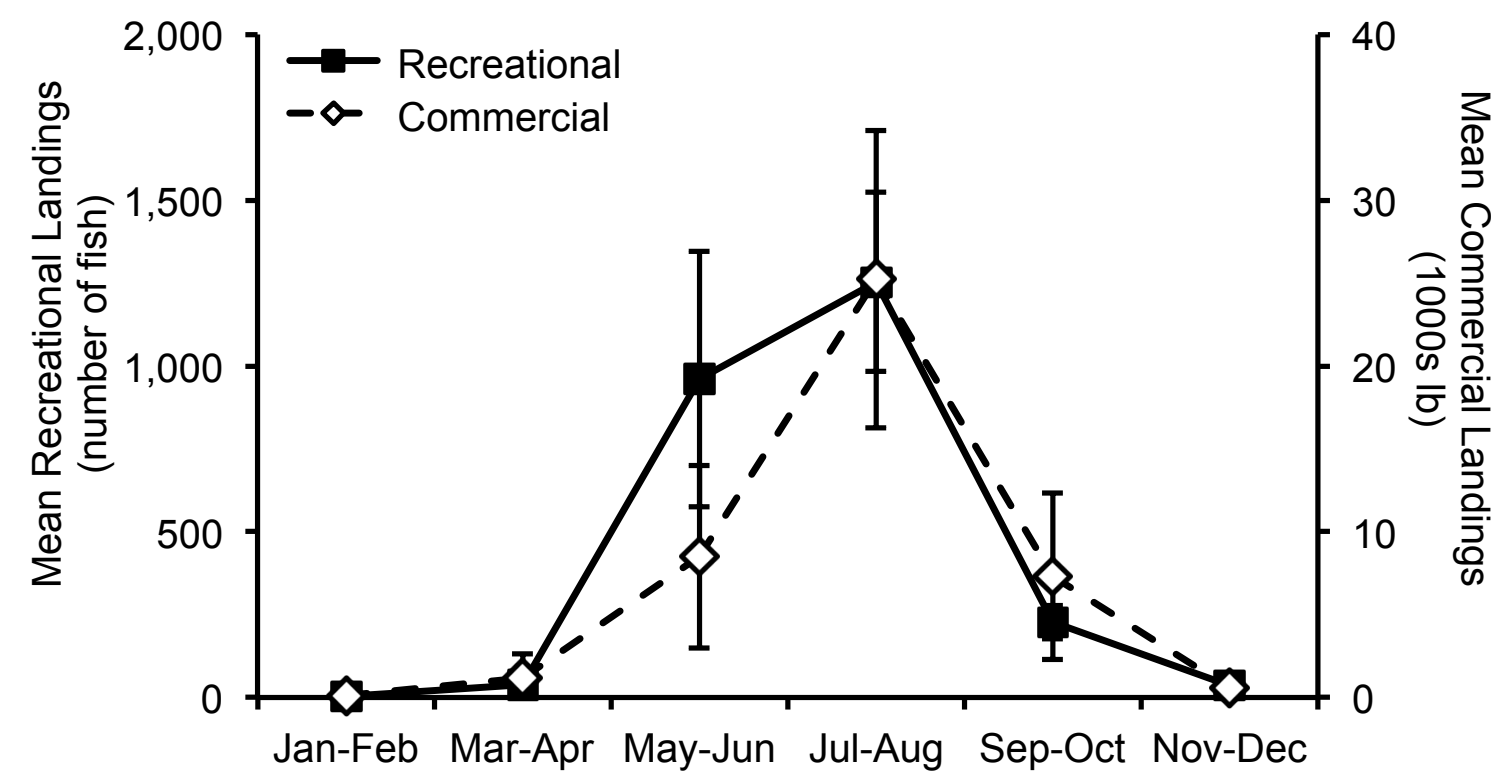

Figure 3. Bimonthly mean landings of California Halibut caught between San Francisco Bay and Morro Bay, CA from 2004 to 2013 (CDFW unpublished data). The solid line represents recreational landings (no. fish) and the dashed line denotes commercial landings $(1000 \mathrm{~s} \mathrm{lb})$. Errors bars indicate one standard error. 
Before the sampling seasons of 2012 and 2013, I posted flyers requesting filleted California Halibut carcasses at every major fishing port, harbor master office, wharf, fishing club, and tackle store from Half Moon Bay in San Mateo County to Grover Beach in San Luis Obispo County. Flyers contained a phone number and email address so that fishers could contact me about donating carcasses during the course of the sampling period. In addition to reaching out to the recreational community, I contacted as many local restaurants and seafood processors as possible to obtain samples from the commercial fishery, as commercial fishers sell their catches as whole fish. California Recreational Fisheries Survey (CRFS) samplers also were asked to collect specimens and distribute informational flyers whenever possible.

Throughout the 2012 sampling period, I spent every weekend and two to three days during the week soliciting California Halibut carcass donations at boat launch ramps and fish cleaning tables. Each sampling day lasted from approximately $10 \mathrm{AM}$, when fishers began to return from early morning trips, to $6 \mathrm{PM}$ or whenever the last boat had returned (whichever came first). One weekend each month, I traveled to Monterey, Morro Bay, and Port San Luis to obtain samples from those locations. However, my sampling efforts were concentrated at Santa Cruz Harbor and Capitola Wharf, where more halibut were being caught recreationally.

In 2013, I enlisted the help of five interns who were each responsible for sampling one of the five sampling locations. Every weekend, from the end of May to the beginning of September, these individuals solicited carcasses from the recreational fishing community in the same way that was described for 2012 
sampling efforts. With all locations staffed on weekends, I traveled from site to site, filled in when needed, attended or staffed Commercial Passenger Fishing Vessel (CPFV) trips targeting California Halibut, and picked up carcasses from fishers calling in with donations. In addition, I collected fish carcasses two to three days during the week at locations not already occupied by CRFS samplers. Finally, I sampled commercially-caught halibut from H\&H Fresh Fish, a seafood processor in Santa Cruz, once per week as long as halibut were being processed.

Capture date, specific location, and gear type were recorded for all specimens collected. When possible, sex, wet body weight ( $\mathrm{kg})$, and pre- and postfillet lengths $(\mathrm{mm})$ were documented. If specimens had already been filleted upon receipt, however, only post-fillet lengths $(\mathrm{mm})$ were obtained. Whether pre- or postfillet, fork length was defined as the shortest distance from the anterior-most portion of the snout to the center of the caudal fin (fig. 4).

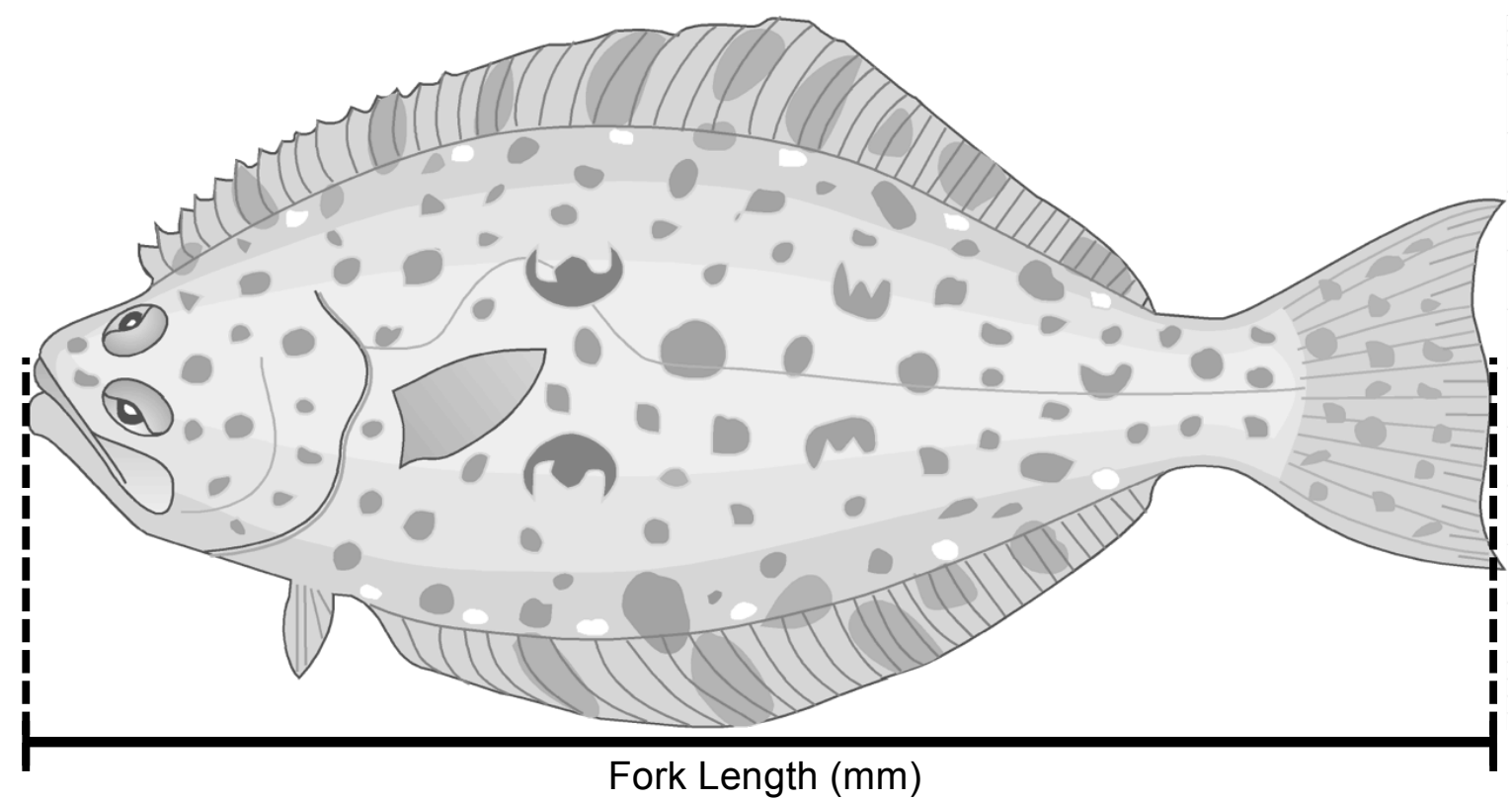

Figure 4. Diagram of fork length measurement. California Halibut, Paralichthys californicus, drawing by $\odot$ Larry G. Allen. 
Once fish were measured in the field, specimens were placed on ice until dissections occurred (typically within $24 \mathrm{hr}$ of capture). During dissections, a miniature handsaw was used to slice through the top of the skull directly adjacent to the migratory eye. Sagittal otoliths (i.e., inner ear bones of ray-finned fishes) were then extracted, cleaned using a paper towel, and stored in coin envelopes for subsequent ageing. Gonads and livers were removed and weighed to the nearest $0.1 \mathrm{~g}$ for calculations of gonadosomatic and hepatosomatic indices (i.e., GSI and $\mathrm{HSI}$, respectively). Ovaries were preserved in $10 \%$ buffered formalin for a minimum of two weeks before being transferred to $70 \%$ ethyl alcohol, where they remained until histological analyses and fecundity estimations were conducted. After mass had been recorded, testes were discarded. Finally, stomach contents, white muscle samples, and fin clips were taken and housed at MLML for future use in diet and/or genetic studies. All specimens were collected under CDFW Scientific Collection Permits 10418 and 824, following SJSU's Institutional Animal Care and Use Committee (IACUC) protocol 985. Unless otherwise stated, statistical analyses were conducted using the IBM software package, SPSS (v.22).

\section{Length-Weight Relationships}

A Kolmogorov-Smirnov (KS) test was used to compare sex-specific length frequency distributions (LFD), whereas an independent samples t-test was used to compare mean fork lengths and mean body weights of California Halibut, by sex. Sex-structured length-weight relationships were also developed for central California Halibut using the allometric growth model $W=a L^{b}$, where $W$ is body weight $(g), L$ is fork length (mm), and a (condition factor) and b (measure of curvature) are constants 
determined by fitting a linear regression to log-transformed length and weight data (Hile 1936, Martin 1949; Le Cren 1951). The slope of the line would correspond to parameter $b$ and the $y$-intercept to parameter $a(\log W=\log a+b \log L)$. Finally, an analysis of covariance (ANCOVA) was used to compare length-weight relationships for males and females.

\section{Age Determinations}

Otoliths were prepared following procedures described by the Committee of Age Reading Experts (CARE 2006). Otoliths were first embedded into a quick set epoxy gel, mounted onto Dennison merchandise tags, and sectioned through the focus (i.e., nucleus or center of the otolith that is defined by the first year of growth) using a Buehler Isomet low-speed saw and $0.5 \mathrm{~mm}$ spacer. Thin sections were then mounted onto microscope slides and polished using a Buehler Ecomet III Polisher/Grinder and 800 to 1000 grit sandpaper until opaque-translucent pairs were distinguishable from one another. Because eyed-side otoliths tended to exhibit distorted patterns of growth, blind-side otoliths were selected for ageing whenever

possible (fig. 5). If the blind otolith for a particular fish was vateritic (i.e., crystallized), damaged (e.g., broken through the focus), or lost, the eyed-side otolith was sectioned and aged in its place (so long as reading difficulty was minimal).

Sectioned otoliths were read at 50x magnification using a compound microscope and transmitted light. Without prior knowledge of fish sex or size, two readers independently determined the age of each fish to the nearest integer (yr). If the otolith margin represented more than six months of growth, the age of the fish was rounded up, whereas a margin exhibiting less than six months of growth would 
result in an age that was rounded down. The relative amount of marginal growth was determined by comparing the width of the band with directly adjacent annuli.

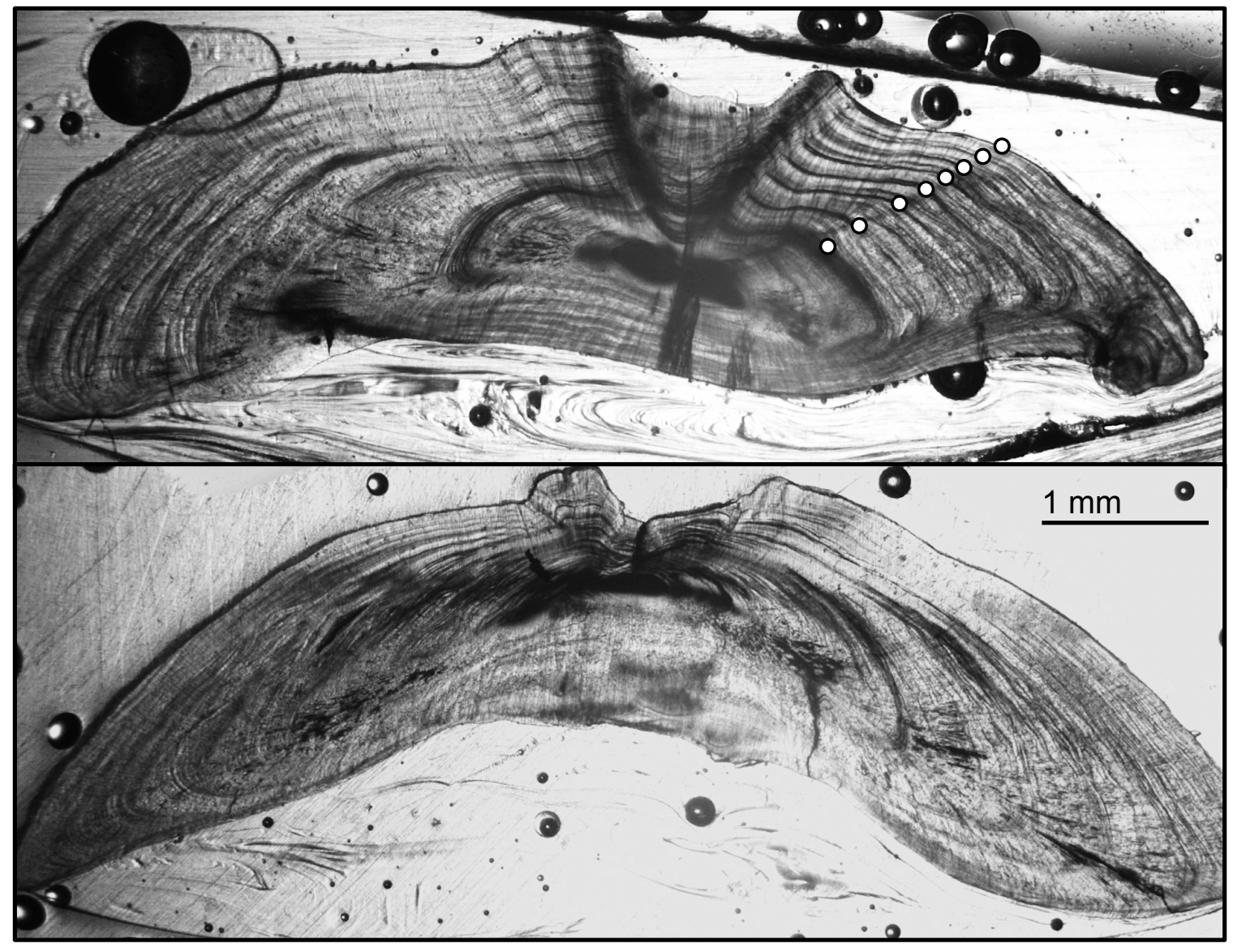

Figure 5. Thin-sectioned sagittal otoliths from two California Halibut, both aged at $8 \mathrm{yr}$ (upper: blind-side otolith, lower: eyed-side otolith). The combination of one opaque and one adjacent, translucent zone represents a single year of growth. White circles (upper image) indicate individual annuli.

Reader 1 (Cheryl Barnes, MLML), less experienced in ageing boney fishes, read each otolith as many times as was necessary to obtain three identical ages. Reader 2 (Paul Reilly, CDFW), more experienced in ageing marine fishes, read each otolith as many times as was necessary to obtain two identical ages. Once age determinations were reached, Reader 1 and Reader 2 compared results. If the two 
agreed, the commonly determined age was considered final. If the age determinations by Reader 1 and Reader 2 did not reach agreement, a third reader (Travis Tanaka, CDFW) was asked to also blindly and independently age the fish. If Reader 3 agreed with either Reader 1 or Reader 2 , that age was considered final. If the age determination made by Reader 3 did not agree with either Reader 1 or Reader 2, a digital image was prepared for discussion purposes. Upon reviewing this image together, all three readers either came to an agreement as to the final age of the fish or decided to exclude it from further analyses because of poor otolith readability. The same ageing procedures were followed for all CDFW-collected data. However, only Readers 2 and 3 were available to age fish collected between 2007 and 2011 and in 2014.

Reader-specific ages for central California Halibut collected during 2012 and 2013 were plotted against one another to evaluate potential biases. Proportional agreement was calculated for each age class to assess between-reader differences for Readers 1 and 2. An independent samples t-test was used to compare mean ages of female and male California Halibut, whereas a Kolmogorov-Smirnov (KS) test compared the shapes of age frequency distributions.

\section{Assessing Rates of Growth}

To estimate growth of California Halibut, sex-structured von Bertalanffy growth curves were fit to length $(\mathrm{mm})$ and age $(\mathrm{yr})$ data using the equation $L_{t}=L_{\infty}\left(1-e^{-K\left(t-t_{0}\right)}\right)$, where $L_{t}$ is the predicted length at age $t, L_{\infty}$ represents the theoretical maximum length, $\mathrm{K}$ is the growth coefficient, and $\mathrm{t}_{0}$ indicates the 
predicted age at a length equal to zero (von Bertalanffy 1938). Because the von Bertalanffy growth equation is sensitive to constricted size ranges and few small fish (i.e., under $600 \mathrm{~mm}$ fork length) were sampled for this study, $\mathrm{t}_{0}$ was fixed at zero (e.g., Ferreira and Russ 1994; Robertson et al. 2005; Caselle et al. 2011). Without doing so, mathematical estimations using project data would have resulted in biologically unrealistic lengths for age-zero fish. Growth parameters $L_{\infty}$ and $K$ were estimated using least squares methods and the Microsoft Excel add-in, Solver. Standard errors for $L_{\infty}$ and $K$ were determined by means of inverse Hessian and variance/covariance matrices (Quinn and Deriso 1999).

Maximum likelihood techniques (described by Kimura 1980) and the statistical software R (v.3.1.1) were used to estimate sex-specific $95 \%$ confidence intervals surrounding $L_{\infty}$ and $K$. These $95 \%$ confidence intervals, depicted as ellipses around the intersection of $L_{\infty}$ and $K$, were plotted and used to statistically evaluate differences between male and female California Halibut. Overlapping ellipses would indicate no significant difference in growth trajectories between the sexes, whereas spatially explicit ellipses would be interpreted as significantly different from one another (e.g., Hamilton et al. 2011). Once this analysis had been completed, length-at-age data collected by CDFW were merged with those collected for this study. The procedures described above were employed to compare sexspecific growth between central and southern California. 


\section{Estimating Total Mortality}

Age frequency data were used to estimate instantaneous rates of total mortality (Z) through catch curve analysis (Ricker 1975). Linear regressions were fit to natural log-transformed frequency data for central California Halibut collected in 2013. The resulting slopes indicated the instantaneous total mortality rate for each sex. An ANCOVA was used to test for significant differences between natural-log transformed age frequencies and sex and the interaction term. A significant interaction term (i.e., slope) would indicate different rates of total mortality, whereas statistical significance in the sex variable (i.e., y-intercept) would indicate differences in relative abundance. The same procedures detailed above were used to evaluate differences between central and southern California Halibut after incorporation of CDFW-collected data from both regions.

\section{Maturity Staging}

Simple determinations of maturity (i.e., immature or mature) were assigned to freshly dead fish using the presence or absence of visible eggs or sperm as criterion (Love and Brooks 1990). In collaboration with Kristine Lesyna (CDFW), who collected large quantities of relatively small individuals $(<600 \mathrm{~mm}$ fork length) from San Francisco Bay during 2012 and 2013, I developed a system in which to classify California Halibut into various stages of maturity. Macroscopic criteria were established according to gonadal size, color, texture, and overall appearance, whereas microscopic criteria were developed via histology.

To prepare preserved ovarian tissue for histological analyses, one 3 to $5 \mathrm{~mm}$ thick transverse section was removed from all retained ovaries. Anterior, mid, and 
posterior sections from both eyed- and blind-side ovaries had been preliminarily analyzed for potential differences in the most advanced developmental oocyte stage. Because no differences existed (Kristine Lesyna pers. comm., 350 Harbor Blvd, Belmont, CA 94002), transverse sections were taken only from the mid-portion of blind-side ovaries. Each section was then placed into a $25 \times 30 \times 4 \mathrm{~mm}$ tissue cassette and $70 \%$ ethyl alcohol. Labeled cassettes were sent to Diagnostic Pathology Medical Group (DPMG) in Sacramento, CA and processed following Luna (1968). Tissues were dehydrated in alcohol, embedded in paraffin, and sectioned to 3 or $4 \mu \mathrm{m}$. Sectioned tissue underwent a six-step procedure [i.e., deparaffinizing, hydrating, hematoxylin and eosin (H\&E) staining, dehydrating, clearing, and mounting] that resulted in the illumination of various cellular features (e.g., nuclei, cytoplasm, collagen) via differential incorporation of H\&E stains.

Once returned to MLML, histological slides were systematically reviewed under a compound microscope at 50x magnification to determine the first (e.g., hydrated) and second (e.g., final maturation) most advanced stage (MAS) of oocyte development using terminology standardized by Murua et al. (2003) (fig 6). Presence of absence of post-ovulatory follicles (POFs; evidence of recent spawning activity) and rates of atresia (resorption of oocytes) were assessed using techniques described by Hunter and Macewicz (1980; 1985) (fig 7). Microscopic maturity stages were determined based upon the combination of MAS of oocyte development, incidence of POFs, and rates of atresia. Macroscopic and microscopic maturity criteria were then organized to inform a complete staging system, which previously had not been undescribed for this species. 


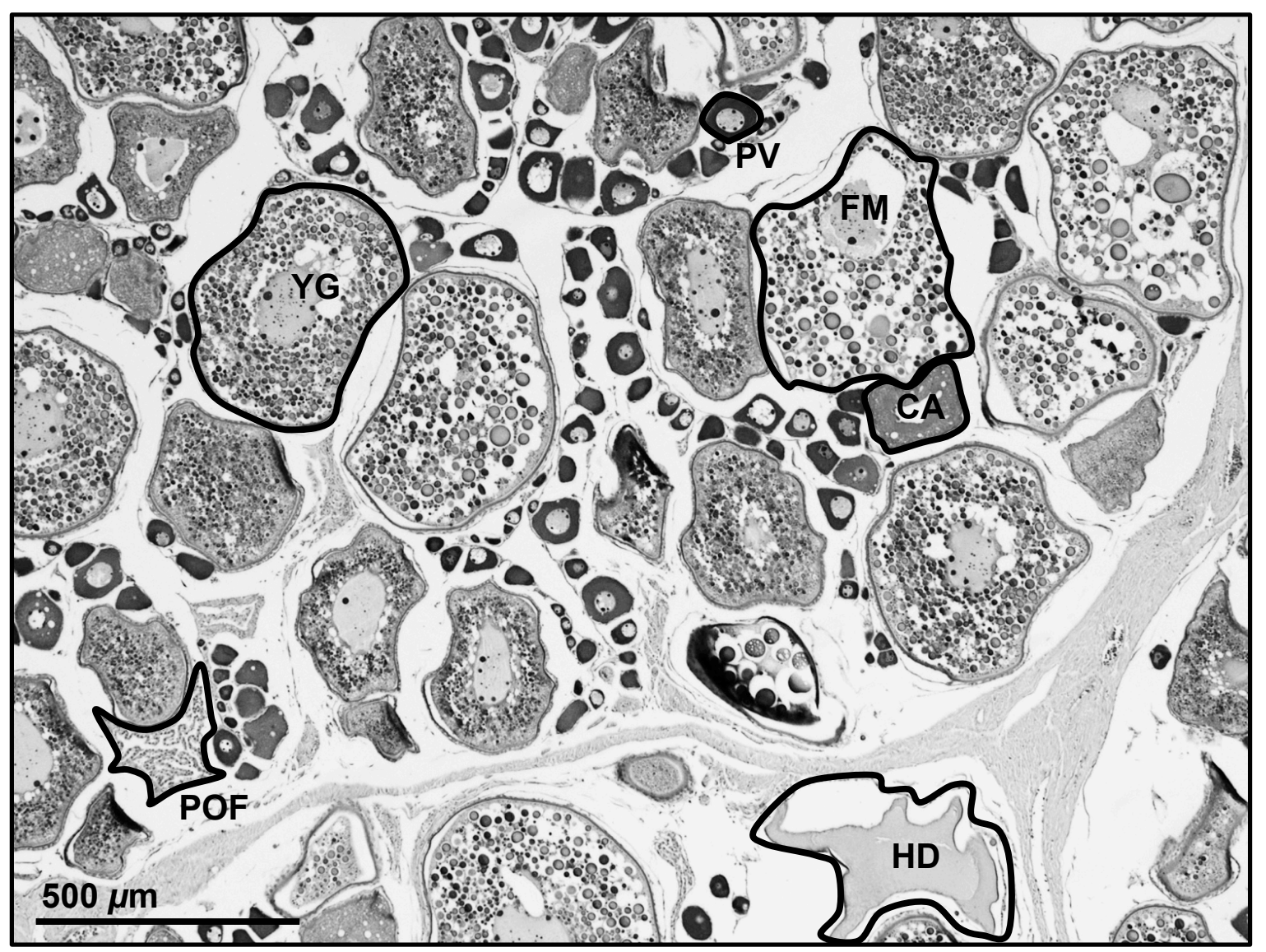

Figure 6. Histological slide of spawning California Halibut ovary indicating various stages of oocyte development used in maturity stage classifications. PV: previtellogenic (i.e., chromatin nuclear, perinucleolar); CA: cortical alveoli; YG: yolk granule; FM: final maturation; HD: hydrated; POF: postovulatory follicle. 


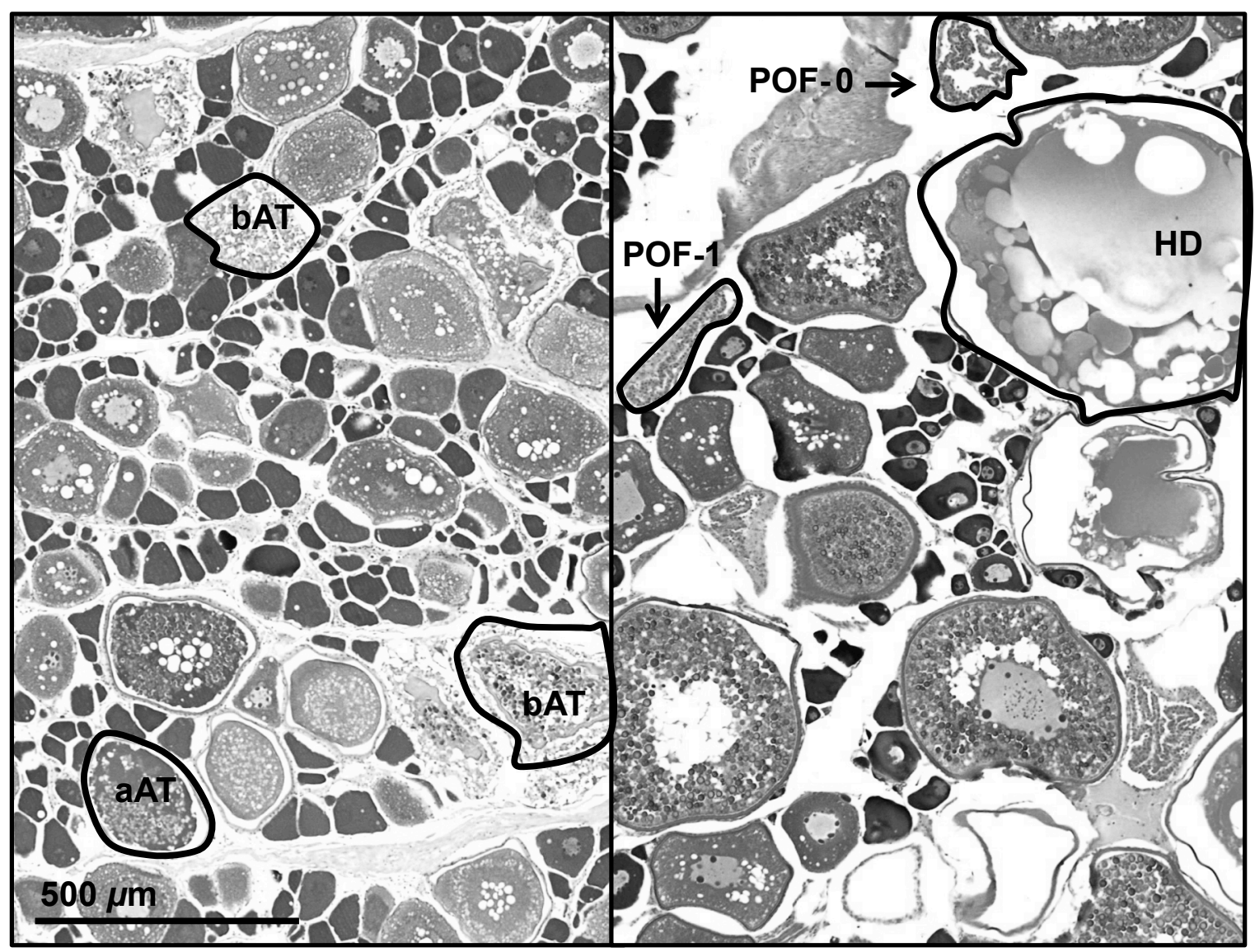

Figure 7. Histological slide of spent (left) and spawning (right) California Halibut ovaries indicating various stages of oocyte development used in maturity stage classifications. HD: hydrated; POF-0: postovulatory follicle theoretically formed on the day of capture; POF-1: postovulatory follicle theoretically formed one day before capture; AT: alpha (primary stage) atresia; bAT: beta (secondary stage) atresia.

\section{Characterization of the Spawning Season}

The incidence of spawning females [i.e., those containing hydrated oocytes and/or new (i.e., age 0) postovulatory follicles] was used to determine the duration of the spawning season (e.g., Almatar et al. 2004). In other words, the earliest capture date of an actively spawning female denoted the start of the summer spawning season, whereas the latest capture date of an actively spawning female indicated the termination of the season. Gonadosomatic index (GSI) and hepatosomatic index 
$(\mathrm{HSI})$ were calculated throughout the sampling period to illustrate temporal changes in energy allocation, which can be used to illustrate the height of spawning activity and provide support for the duration of a spawning season (Le Cren 1951; Delahunty and de Vlaming 1980; de Vlaming et al. 1982). The equations used to calculate standardized GSI and HSI were:

$$
\begin{aligned}
& \mathrm{GSI}=\frac{\text { ovary mass }(\mathrm{g})}{\text { body mass }(\mathrm{g}) \text { - ovary mass }(\mathrm{g})} * 100 \\
& \mathrm{HSI}=\frac{\text { liver mass }(\mathrm{g})}{\text { body mass }(\mathrm{g}) \text { - liver mass }(\mathrm{g})} * 100
\end{aligned}
$$

Relatively greater values of GSI represent increased energy allocation toward reproduction at the time of capture. Conversely, greater values of HSI represent increased energy allocation toward growth and maintenance (Delahunty and de Vlaming 1980). However, in oviparous fishes, HSI can increase in conjunction with reproductive activity because synthesis of vitellogenin (the egg yolk precursor protein) takes place in the liver (Wallace and Selman 1979). Therefore, temporal changes in $\mathrm{HSI}$ are confounded for females and may only be indicative of changes in energy allocation for males.

\section{Daily Spawning Fraction, Interspawning Interval, Spawning Frequency}

To determine the daily spawning fraction (s) of central California Halibut, the number of spawning females sampled was divided by the total number of females capable of reproducing at the time of capture (e.g., Parker 1980; DeMartini and Fountain 1981; Hunter and Macewicz 1985; Caddell et al. 1990; Almatar et al. 2004). Interspawning interval (ISI, in days) was calculated by taking the reciprocal of the 
daily spawning fraction (ISI $=\frac{1}{\mathrm{~s}} ;$ Wootton 1978). Daily spawning fraction and interspawning interval were calculated for each sampling day that produced three or more reproductively capable females. To prevent underestimations of daily spawning fraction due to the ephemeral nature of hydration and spawning, only females possessing postovulatory follicles (POFs) estimated to be one day old were used in the numerator (e.g., Hunter and Goldberg 1980; Hunter and Macewicz 1980; Hunter and Macewicz 1985). Spawning frequency (f), defined as the number of spawning events per female per season, was estimated by dividing the duration of the spawning season by the interspawning interval. Spawning frequency was estimated for central California Halibut for 2012, 2013, and for both years combined.

\section{Batch Fecundity}

The gravimetric method of estimating fecundity includes calculating the product of gonad mass $(\mathrm{g})$ and mean oocyte density (number of eggs per gram of ovarian tissue) (Bagenal 1978; Morse 1981; Hunter et al. 1985). For multiple spawning fishes, batch fecundity (i.e., the number of eggs released during a single spawning event) can be determined by incorporating the hydrated oocyte method into the gravimetric method, which means only counting the number of hydrated oocytes in a weighed subsample to establish mean oocyte density before extrapolating to the full mass of the ovary (Hunter and Goldberg 1980; Macewicz and Hunter 1993).

Because hydrated oocytes represent the spawning batch and are easily distinguishable from earlier stages of development based on size, color, shape, and obvious presence of an oil globule, this method was selected to estimate batch 
fecundity for central California Halibut (fig. 8). Therefore, only females with hydrated oocytes at the time of capture were incorporated into this estimate.

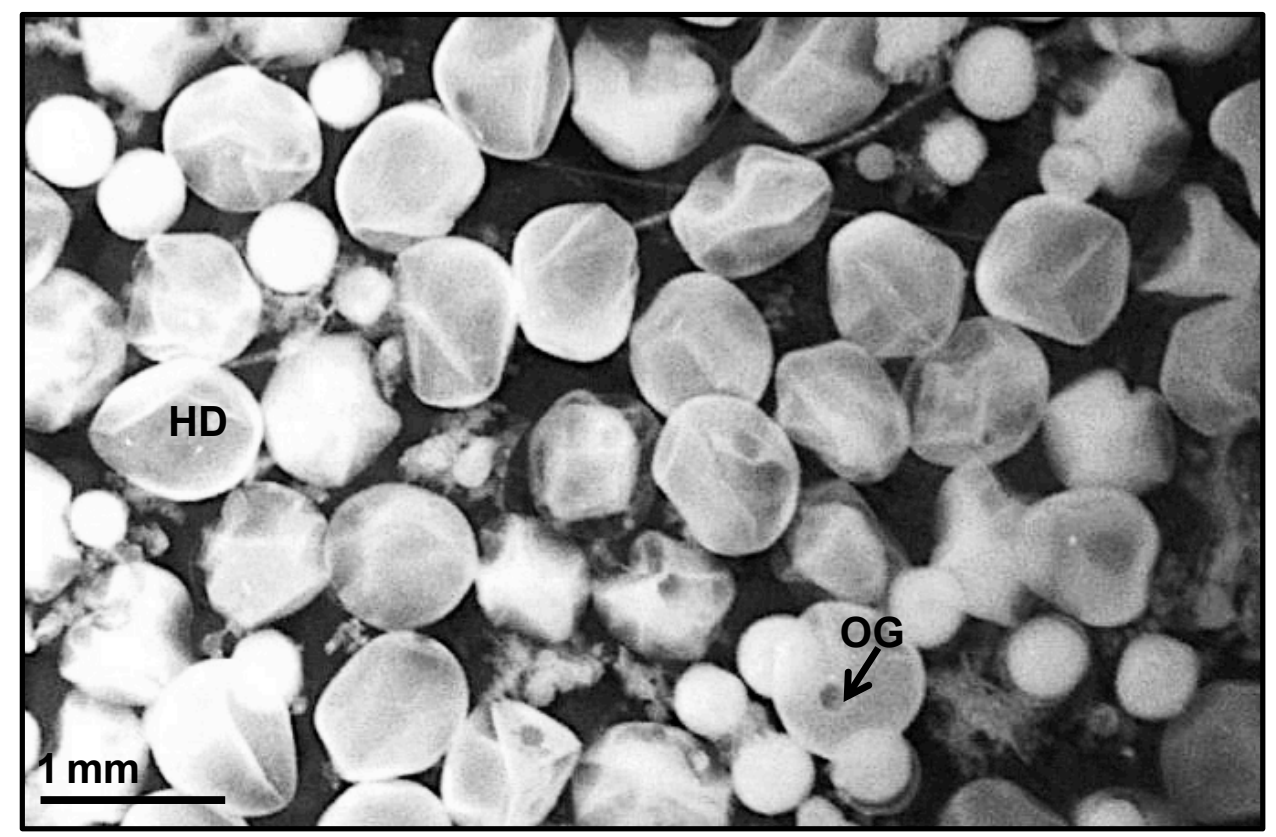

Figure 8. Whole mount image of California Halibut oocytes. Hydrated oocytes (HD) are distinguishable from less developed stages due to their larger size, greater transparency, wrinkled appearance, and obvious oil globule (OG).

Ovaries of hydrated females (as determined from both macroscopic and microscopic evaluation) were removed from preservative, dried on blotter paper for 2 to 3 minutes, and weighed to the nearest $0.1 \mathrm{~g}$. A length-wise incision was then made along the ovary. If hydrated oocytes had uniformly collected at the innermost and/or anterior-most section(s) of the ovary, this "hydrated-only" portion was washed into a separate container using a standard coffee filter and funnel, left to drain until all solution had percolated through, and weighed to the nearest $0.1 \mathrm{~g}$.

Once the hydrated-only portion had been processed (if applicable), remaining oocytes consisting of assorted developmental stages (including some hydrated 
oocytes) were separated from the ovarian wall. The ovarian wall was then weighed to the nearest $0.1 \mathrm{~g}$. Both hydrated-only and ovarian wall masses were subtracted from the initial preserved ovary mass to obtain an estimate of mass for the "assorted" portion (g). The assorted portion was then thoroughly mixed before removing five subsamples ( 0.3 to $0.5 \mathrm{~g}$ each). Because the density of hydrated oocytes in assorted and hydrated-only portions were likely to be different (i.e., much greater densities of hydrated oocytes in hydrated-only portions than in assorted portions), five subsamples also were taken from hydrated-only portions.

Hydrated oocytes were counted for three assorted subsamples and three hydrated-only subsamples (if applicable). The coefficient of variation (CV) was used to determine whether or not this sample size was sufficient to precisely estimate batch fecundity of any one fish. If the $\mathrm{CV}$ from the first three subsample densities exceeded 0.20 , an additional one to two subsamples were counted. The mean subsample density was then calculated and multiplied by the mass of the appropriate assorted or hydrated-only portion. These subtotals were then added together to provide an estimate of batch fecundity for each individual fish. Spawning females with ovaries that had missing portions (as a result of filleting) produced inaccurate preserved masses and were excluded from batch fecundity estimates. Ovaries that had not been properly preserved (i.e., an insufficient ratio of formalin and/or ethanol to tissue) caused degradation and were also excluded from analyses.

California Halibut in a "late hydration" phase of spawning (histologically characterized by possessing hydrated oocytes, but no final maturation stage or new postovulatory follicles) were used to develop a relationship between batch fecundity 
and fork length $(\mathrm{mm})$. Late hydration phase females were selected in an attempt to reduce the variation in batch fecundity by excluding females that had not yet fully hydrated or that had already released some hydrated oocytes (i.e., the batch fecundity estimate for these fish would be artificially low as result of timing of capture). Curve estimation was used to determine the best-fit model for batch fecundity-at-length. Curve estimation also was used to determine the best-fit model for the relationship between batch fecundity of late hydration or actively spawning females and time (Julian day) to evaluate temporal effects on spawning. Finally, the mean batch fecundity for an averaged-sized female was multiplied by the mean spawning frequency to estimate seasonal fecundity for 2012, 2013, and both years combined. 


\section{RESULTS}

A total of 704 specimens were collected as part of this study (table 1;

appendix I). Sampling efforts resulted in the collection of fish on 46 different days in 2012 and on 72 different days in 2013. Although additional effort was expended, sampling days were not recorded if California Halibut had not been collected.

TABLE 1

Number of specimens collected, by sex and sampling location. Fish listed as central California were caught in San Francisco Bay, Half Moon Bay, or an undetermined location within Monterey Bay.

\begin{tabular}{lrrr}
\hline \multirow{2}{*}{ Location } & \multicolumn{2}{c}{ Sex } & \\
& Female & Male & Total \\
\hline Central California & 13 & 3 & 16 \\
Santa Cruz & 172 & 117 & 289 \\
Moss Landing & 177 & 119 & 296 \\
Monterey & 35 & 7 & 42 \\
Morro Bay & 19 & 8 & 27 \\
Port San Luis & 32 & 2 & 34 \\
\hline Total & 448 & 256 & 704 \\
\hline
\end{tabular}

All but three fish were obtained from fishery-dependent sources. Of the 701 California Halibut collected from the fishery, $34 \%$ were supplied by the commercial sector (either directly or from seafood processors) and 60\% came from recreational anglers and spear divers (table 2). Sources for the remaining $6 \%$ could not be determined. The sex ratio of fish collected exclusively for my thesis was 1.8:1 (female to male), which was significantly different from the expected $1: 1$ ratio $\left(X^{2}{ }_{1,702}=52.364, p<0.001\right)$. When my data were combined with those collected by 
CDFW, the sex ratio for central California became 1.4:1 $\left(X_{1,1297}^{2}=26.290\right.$, $p<0.001)$. Data for southern California Halibut displayed a sex ratio of $4.3: 1\left(X^{2}{ }_{1,759}\right.$ $=291.512, p<0.001)$.

TABLE 2

Number of specimens collected, by fishery and gear type. Three additional fish were collected using fishery-independent methods.

\begin{tabular}{lcccc}
\hline Gear Type & Commercial & $\begin{array}{c}\text { Number of Fish } \\
\text { Recreational }\end{array}$ & Unknown & Total \\
\hline Hook-and-Line & 235 & 319 & 42 & 596 \\
Spear & 0 & 94 & 0 & 94 \\
Unknown & 4 & 6 & 1 & 11 \\
\hline Total & 239 & 419 & 43 & 701 \\
\hline
\end{tabular}

\section{Length-Weight Relationships}

Because specimens were opportunistically collected from commercial and recreational fisheries, many were received as filleted carcasses. Therefore, obtaining pre-fillet fork length $(\mathrm{mm})$ for length-weight relationships was not always possible. To assess the relationship between pre- and post-fillet length, a linear regression was fit to data from 152 individuals for which both pre- and post-fillet fork length measurements existed (fig. 9). The resulting regression equation was $y=1.01 x-0.94\left(R^{2}=0.999, F_{1,150,}=279210, p<0.001\right)$, where $x$ equals pre-fillet fork length $(\mathrm{mm})$ and $y$ equals post-fillet fork length $(\mathrm{mm})$. Given that the relationship between pre- and post-fillet fork length was directly proportional, post-fillet length was converted to pre-fillet length when no pre-fillet length measurement was 
available. Pre-fillet fork length $(\mathrm{mm})$, either measured or converted, was used in all proceeding analyses and is simply referred to as 'fork length' forward-going.

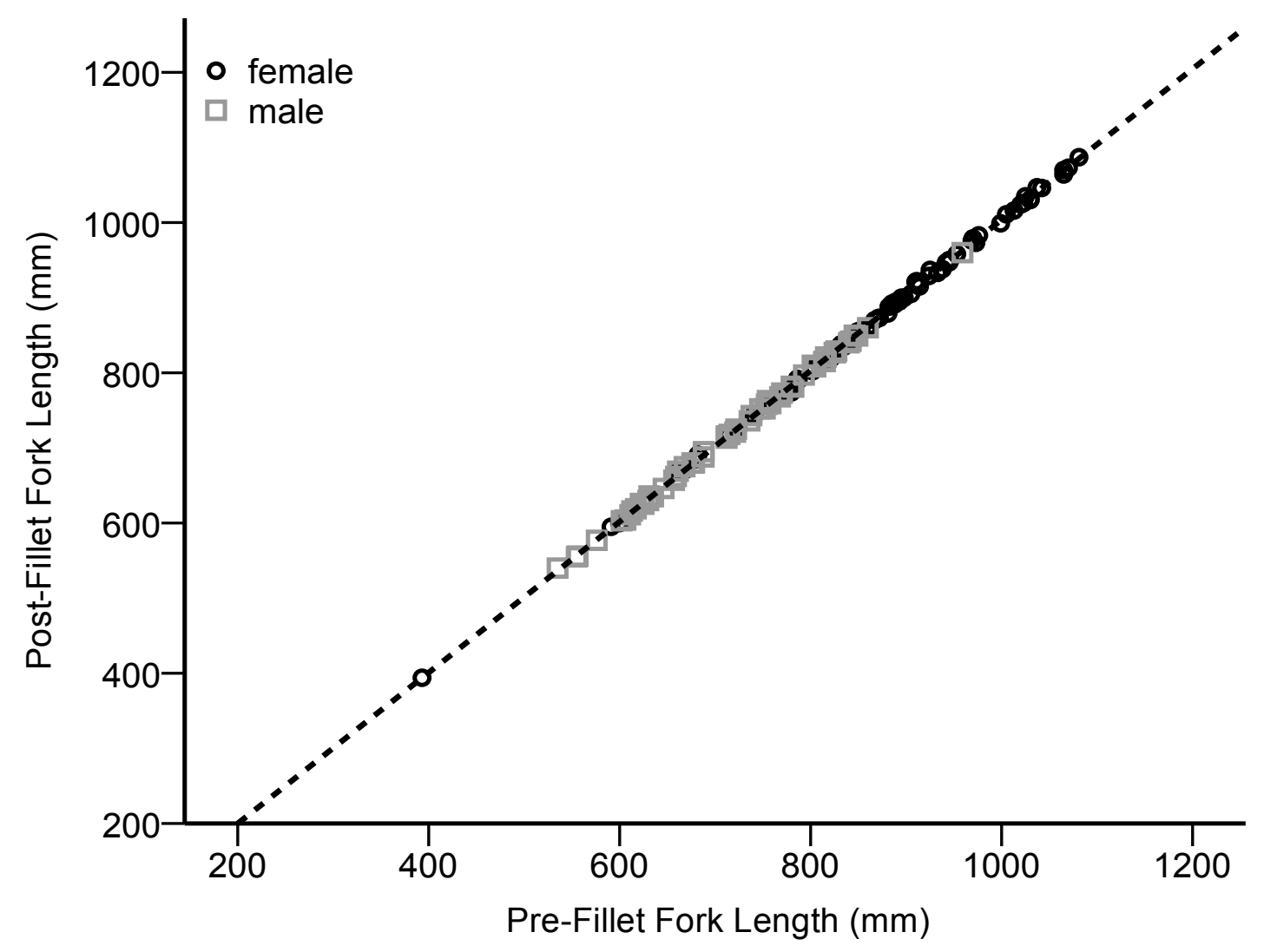

Figure 9. Relationship between pre- and post-fillet fork length $(\mathrm{mm})$ measurements for California Halibut $(n=152)$. Black circles denote females and gray squares denote males. The black dashed line indicates the predicted post-fillet fork length $(\mathrm{mm})$ at any particular pre-fillet fork length $(\mathrm{mm})$, given the equation $\mathrm{y}=1.01 \mathrm{x}-0.94$ $\left(R^{2}=0.999, F_{1,150}=279210, p<0.001\right)$.

An independent samples t-test indicated that female California Halibut had a greater mean fork length $(\mathrm{mm})$ than males $\left(t_{627}=19.018, p<0.001\right)$. Females also attained a greater maximum length, with the largest female measuring $1172 \mathrm{~mm}$ and the largest male measuring $977 \mathrm{~mm}$ (table 3). A two-sample KS test indicated that length frequency distributions (LFDs) were significantly different between the sexes $(D=0.569, p<0.001 ;$ fig. 10). The female LFD $(n=444)$ was leptokurtic 
(kurtosis $=0.655 \pm 0.231)$ and slightly skewed to the left (skewness $=-0.154 \pm$

$0.116)$, whereas the male LFD $(n=256)$ was platykurtic (kurtosis $=-0.317 \pm 0.303)$ and slightly skewed to the right (skewness $=0.179 \pm 0.152$ )

TABLE 3

Minimum, mean (standard deviation), and maximum fork lengths $(\mathrm{mm})$ for central California Halibut, by sex. Sample sizes (n) are indicated.

\begin{tabular}{rcc}
\hline & \multicolumn{2}{c}{ Fork length $(\mathrm{mm})$} \\
Descriptive Statistic & $\begin{array}{c}\text { Female } \\
(\mathrm{n}=444)\end{array}$ & $\begin{array}{c}\text { Male } \\
(\mathrm{n}=256)\end{array}$ \\
\hline Minimum & 393 & 451 \\
Mean (SD) & $850(110)$ & $705(88)$ \\
Maximum & 1172 & 977 \\
\hline
\end{tabular}

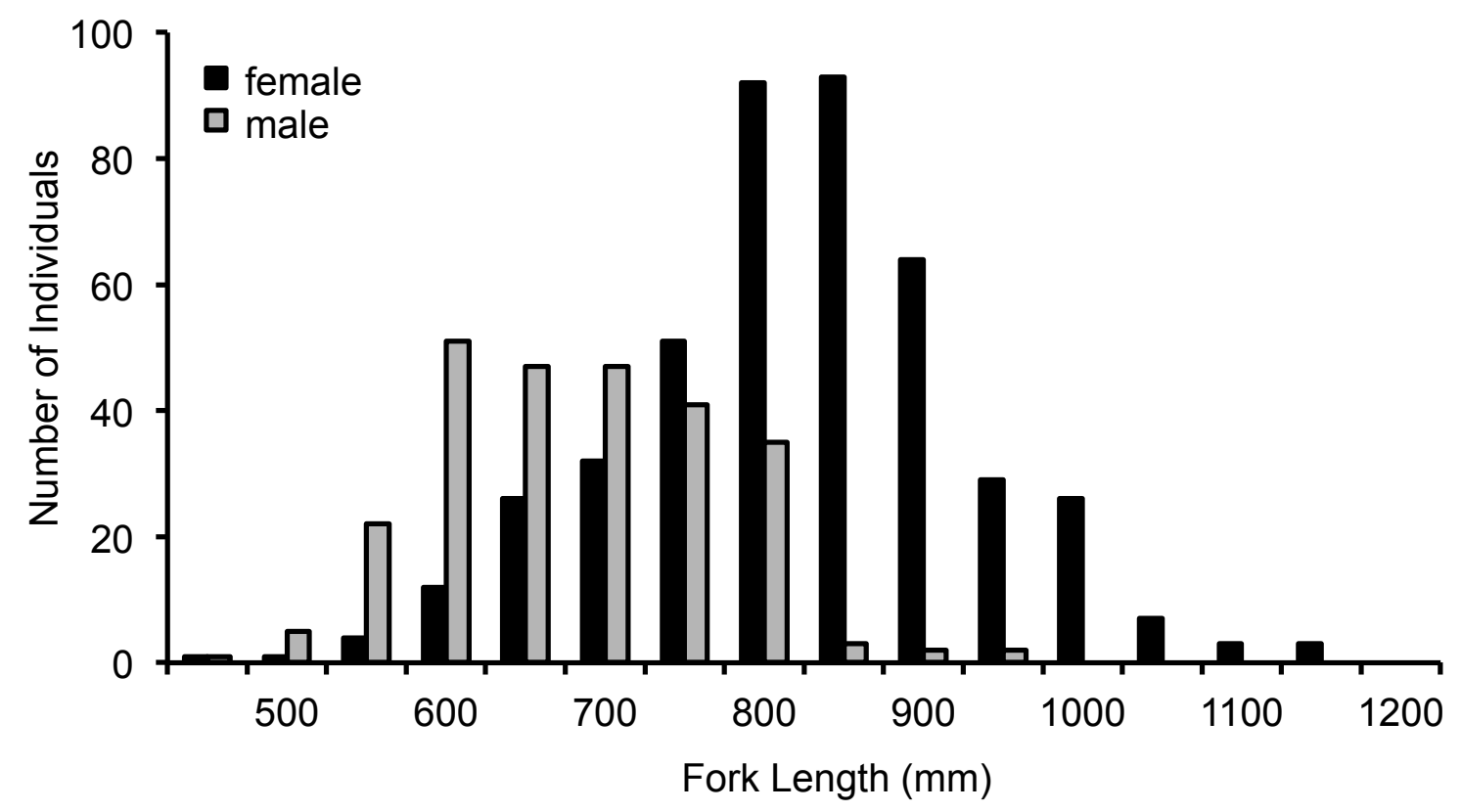

Figure 10. Length frequency distributions for central California Halibut, by sex. Black bars indicate females and gray bars indicate males. 
Fitting a linear regression to log-transformed length-weight data resulted in a relationship of $W=6.421 E^{-6} L^{3.090}\left(R^{2}=0.930, F_{1,224}=2964, p<0.001\right)$ for females and $W=1.080 E^{-5} L^{3.006}\left(R^{2}=0.940, F_{1,109}=1705, p<0.001\right)$ for males. The relationship between fork length $(\mathrm{mm})$ and wet body weight $(\mathrm{g})$ is a power function, with weight increasing more rapidly at greater lengths, for both sexes (fig. 11).

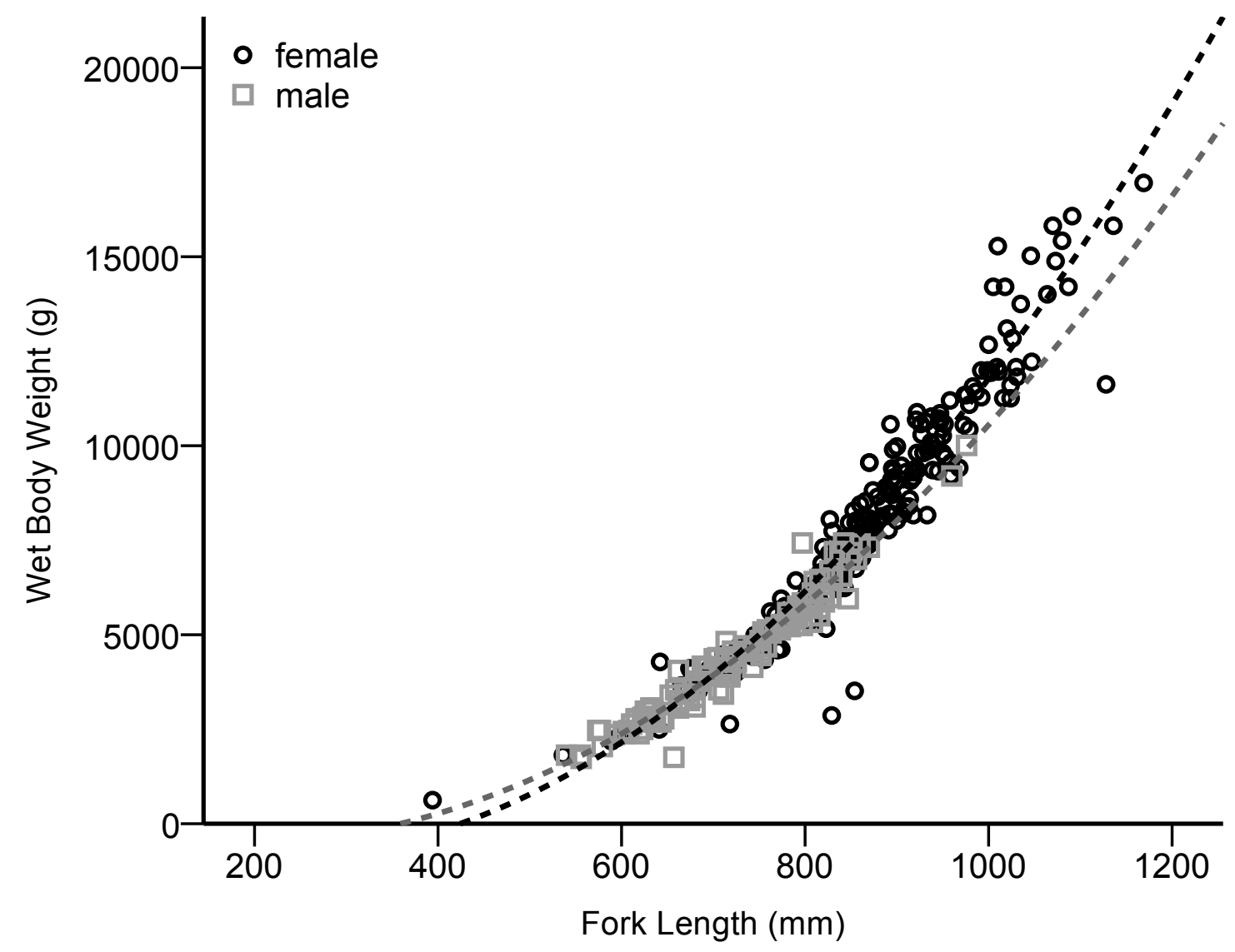

Figure 11. Relationship between fork length $(\mathrm{mm})$ and wet body weight $(\mathrm{g})$ for California Halibut caught off of central California. Black circles represent females and gray squares represent males. The dashed lines with corresponding colors indicate the predicted weight $(\mathrm{g})$ at length $(\mathrm{mm})$.

Although length-weight relationships appear similar to $900 \mathrm{~mm}$, a divergence at greater lengths produced significant differences in the relationships by sex 
(ANCOVA, $\left.F_{1,334}=4.882, p=0.028\right)$. An independent samples $t$-test indicated that female California Halibut $(n=228)$ exhibited significantly greater mean body weight (g) than males $\left(n=111 ; t_{332}=13.884, p<0.001\right)$. Female California Halibut also attained a greater maximum body weight at $16,953 \mathrm{~g}$ when compared to males, which measured to a maximum of $10,008 \mathrm{~g}$ (table 4 ). This substantial difference results from a three-fold effect of length on weight and an almost $200 \mathrm{~mm}$ difference in maximum lengths between the sexes.

TABLE 4

Minimum, mean (standard deviation), and maximum wet body weights (g) for central California Halibut, by sex. Sample sizes (n) are indicated.

\begin{tabular}{rcc}
\hline & \multicolumn{2}{c}{ Wet Body Weight $(\mathrm{g})$} \\
Descriptive Statistic & $\begin{array}{c}\text { Female } \\
(\mathrm{n}=228)\end{array}$ & $\begin{array}{c}\text { Male } \\
(\mathrm{n}=111)\end{array}$ \\
\hline Minimum & 624 & 1,729 \\
Mean (SD) & $8,011(3,040)$ & $4,452(1,672)$ \\
Maximum & 16,953 & 10,008 \\
\hline
\end{tabular}

\section{Reader Agreement in Ageing California Halibut}

In ageing central California Halibut, Readers 1 and 2 agreed $51.3 \%$ of the time (i.e., 235 out of 457 fish). The maximum difference between age determinations by Reader 1 and Reader 2 was six years. Out of 222 disagreements, 163 were one year apart, 44 were two years apart, and 15 were three to six years apart. From these disagreements, 133 were settled by supplementary reads from Reader 3. The remaining 89 otoliths were photographed and discussed by all three readers until a final age was unanimously determined. Ten otoliths (not listed in the 
sample sizes above) were excluded from analyses because processing or obscured growth patterns made them too difficult to age.

Readers 1 and 2 tended to age fish more similarly at younger ages than at older ages (fig. 12). When age determinations differed, Reader 2 generally obtained younger values than Reader 1 . The linear relationship between ages determined by Reader 1 and Reader 2 was $y=0.82 x+1.16\left(R^{2}=0.814, F_{1,455}=1991, p<0.001\right)$. Comparisons of age determinations by Readers 1 and 3 revealed a fluctuation above and below complete agreement throughout the age range $(y=0.82 x+1.69$, $R^{2}=0.732, F_{1,222}=607, p<0.001$ ), typically within one year (fig. 13). Age determinations by Readers 2 and 3 were closest to one another $(y=0.94 x+1.19$, $\left.R^{2}=0.777, F_{1,222}=773, p<0.001\right)$ with exceptions at 3,11 , and 13 years of age, due primarily to small sample sizes for those age classes (fig. 14). A linear regression, fit to proportional agreement at age for Readers 1 and 2, illustrated a decline in agreement with increasing age $\left(F_{1,14}=94.508, p<0.001\right.$; fig. 15). 


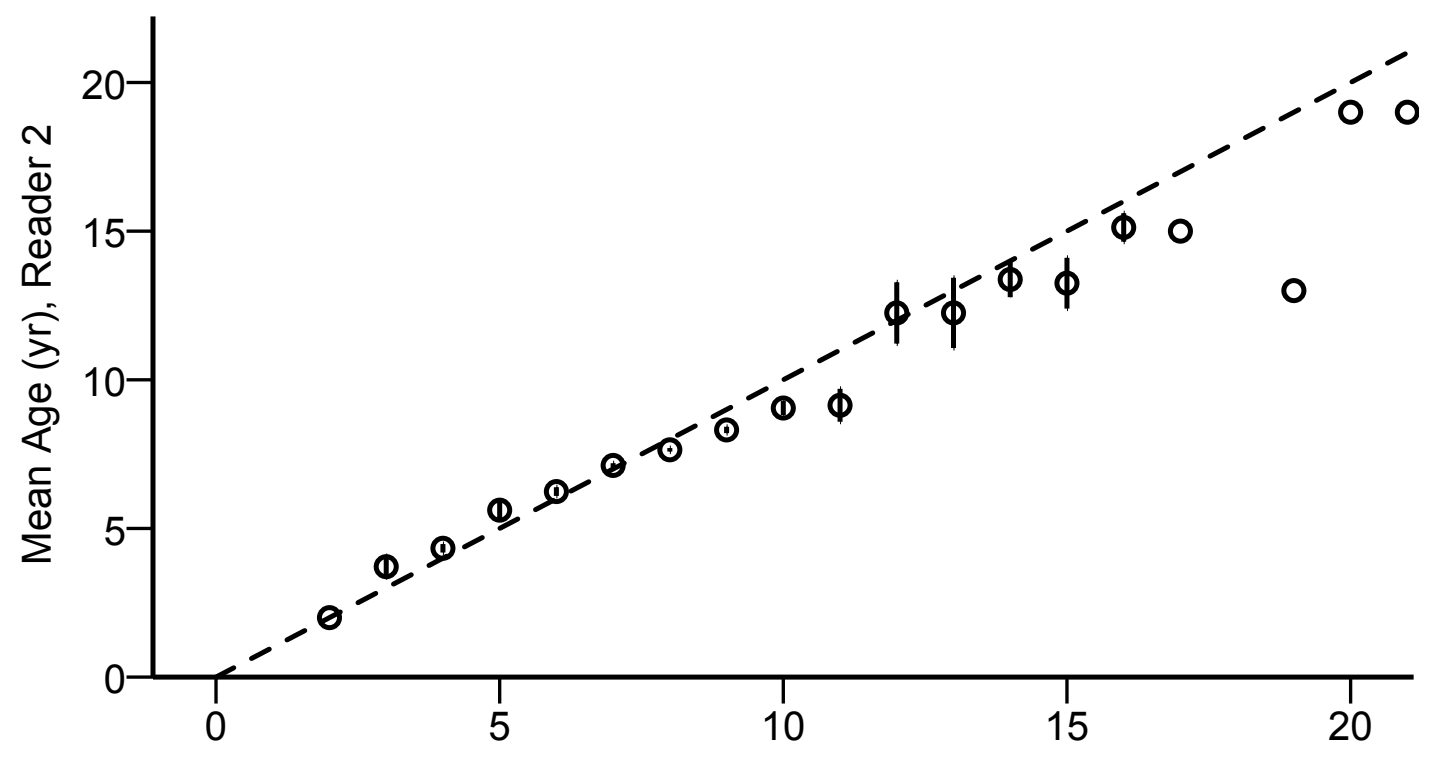

Age (yr), Reader 1

Figure 12. Mean ages (yr) for Reader 2, as compared with ages (yr) determined by Reader $1(n=457)$. Error bars represent one standard error above and below the mean. The dashed line indicates a theoretical one-to-one relationship.

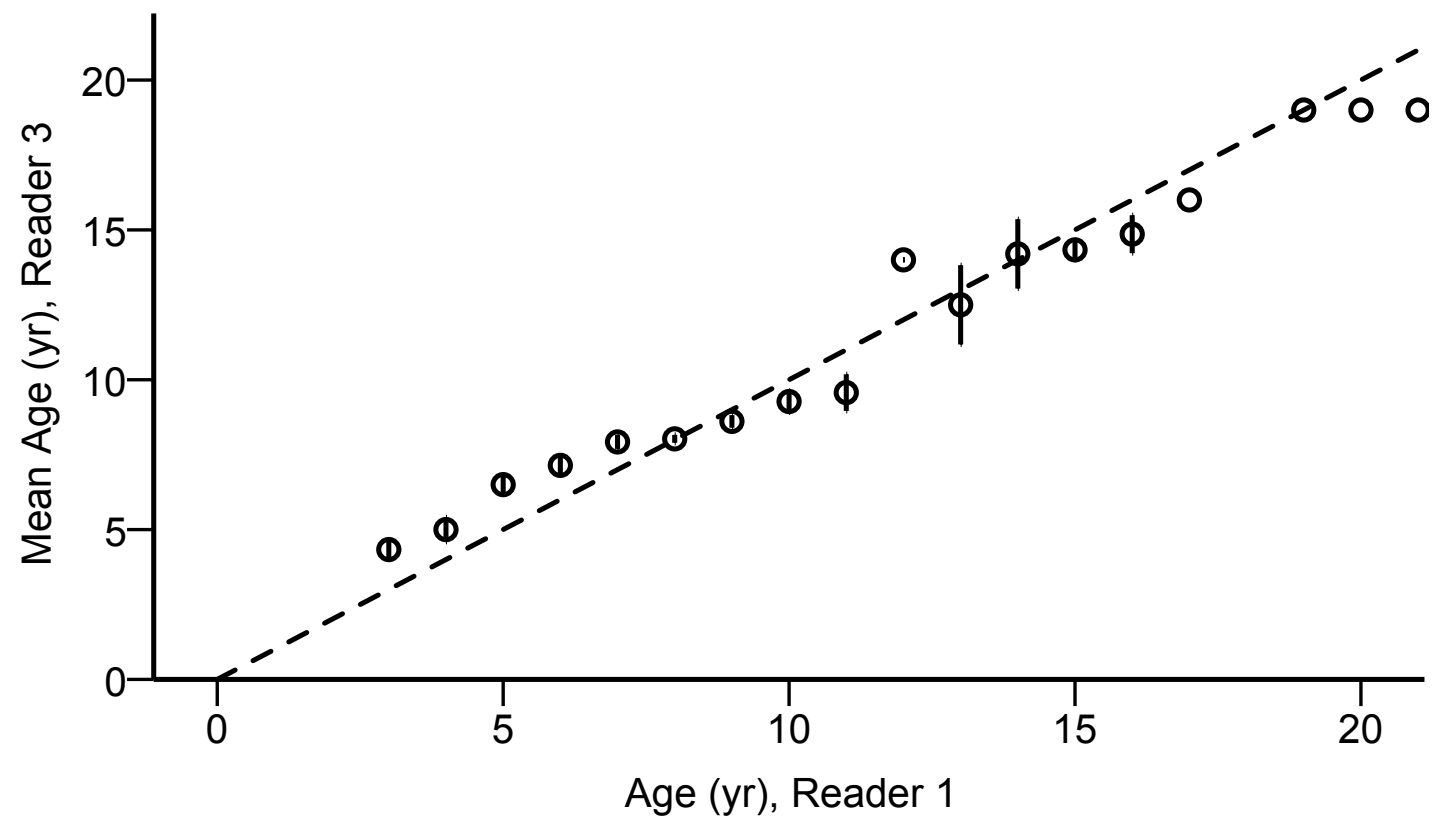

Figure 13. Mean ages (yr) for Reader 3 , as compared to ages (yr) determined by Reader $1(n=224)$. Error bars represent one standard error above and below the mean. The dashed line indicates a theoretical one-to-one relationship. 


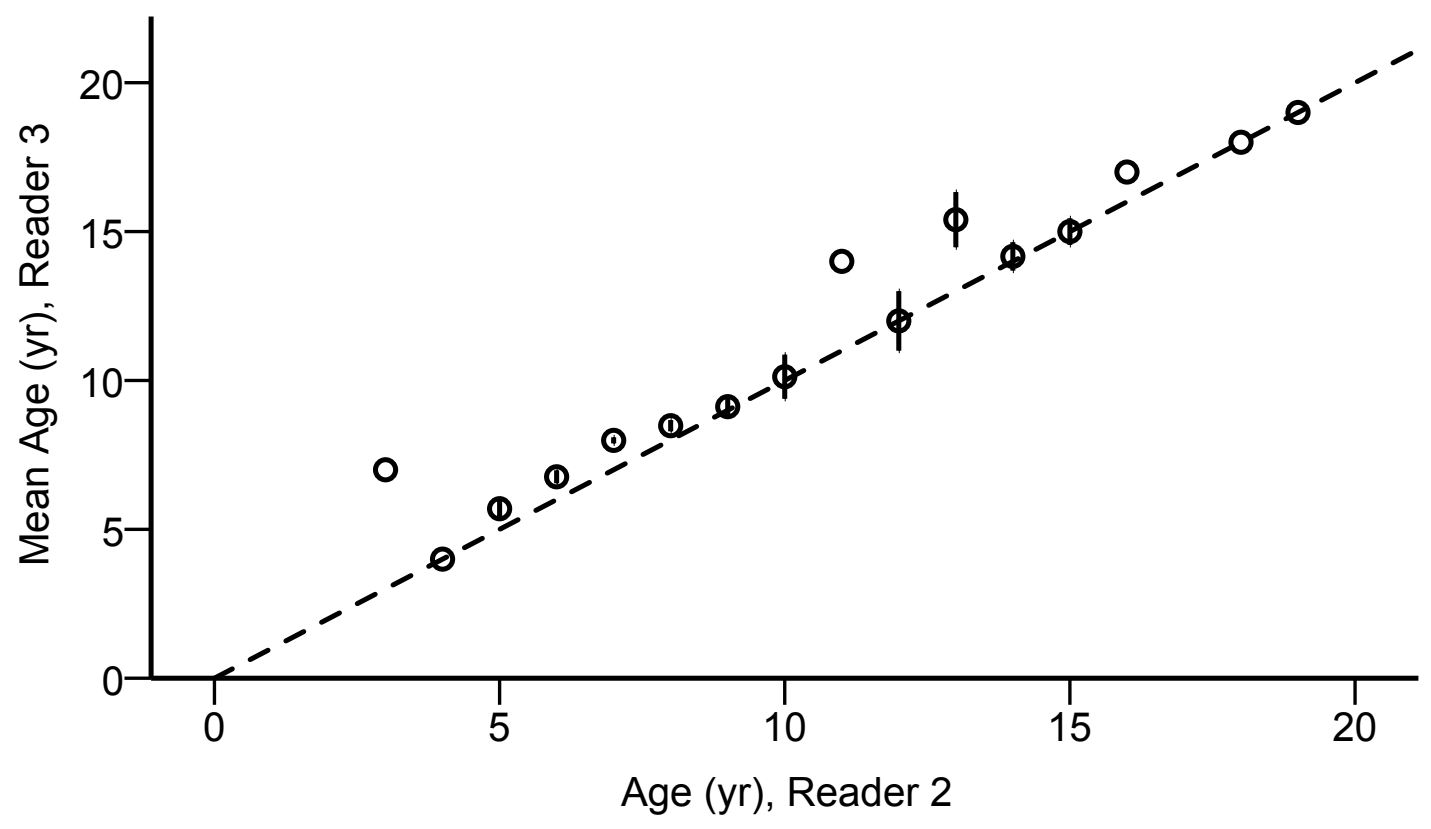

Figure 14. Mean ages (yr) for Reader 3, as compared to ages (yr) determined by Reader $2(n=224)$. Error bars represent one standard error above and below the mean. The dashed line indicates a theoretical one-to-one relationship.

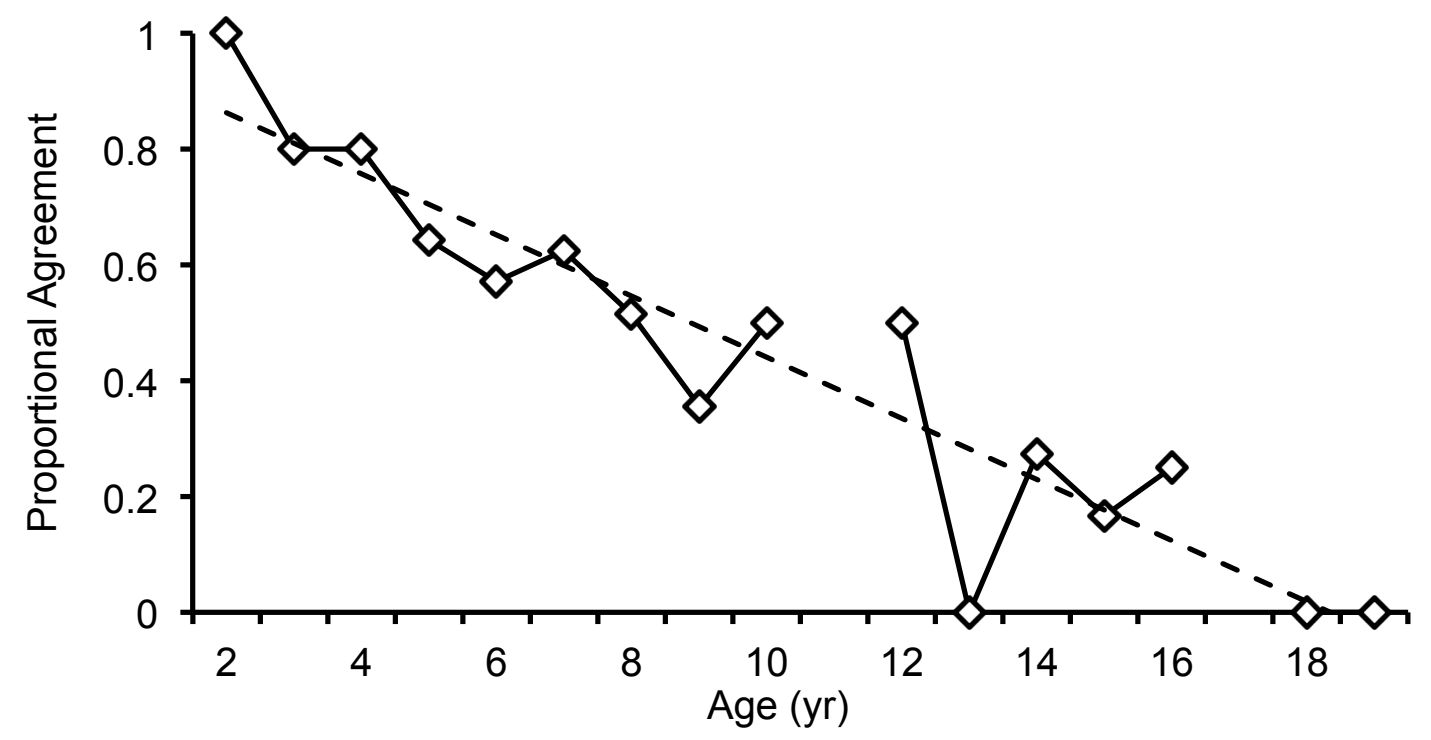

Figure 15. Proportional agreement between Reader 1 and Reader 2, by age (yr). The dashed line represents the best-fit linear relationship between age and proportional agreement $\left(y=-0.05 x+0.92 ; R^{2}=0.871, p<0.001, n=457\right)$. 


\section{Age Compositions}

An independent samples t-test indicated that there was no significant difference in mean ages of female $(n=280)$ and male $(n=177)$ California Halibut collected as part of this study $\left(t_{455}=0.624, p=0.553\right)$. However, females reached an older maximum age of $19 \mathrm{yr}$, whereas males were aged to $16 \mathrm{yr}$ (table 5).

TABLE 5

Minimum, mean (standard deviation), and maximum ages (yr) for central California Halibut, by sex. Sample sizes (n) are indicated.

\begin{tabular}{rcc}
\hline & \multicolumn{2}{c}{ Age $(\mathrm{yr})$} \\
Descriptive Statistic & $\begin{array}{c}\text { Female } \\
(\mathrm{n}=280)\end{array}$ & $\begin{array}{c}\text { Male } \\
(\mathrm{n}=177)\end{array}$ \\
\hline Minimum & 2 & 3 \\
Mean (SD) & $8.1(2.4)$ & $8.0(2.1)$ \\
Maximum & 19 & 16 \\
\hline
\end{tabular}

A two-sample KS test indicated similar age structures for female and male California Halibut $(D=0.085, p=0.409)$. Both age frequency distributions were highly leptokurtic (kurtosis: female $=6.251 \pm 0.290$, male $=5.227 \pm 0.363 \mathrm{SE}$ ) and skewed to the right (skewness: female $=1.738 \pm 0.146$, male $=1.872 \pm 0.183$ ). $\mathrm{A}$ peak was evident for fish aged between 7 and $9 \mathrm{yr}$, corresponding with the 2006 , 2005, and 2004 year classes (fig. 16). Additionally, low frequencies of 11, 12, and 13 year-old fish from the 2002, 2001, and 2000 year-classes were evident. 


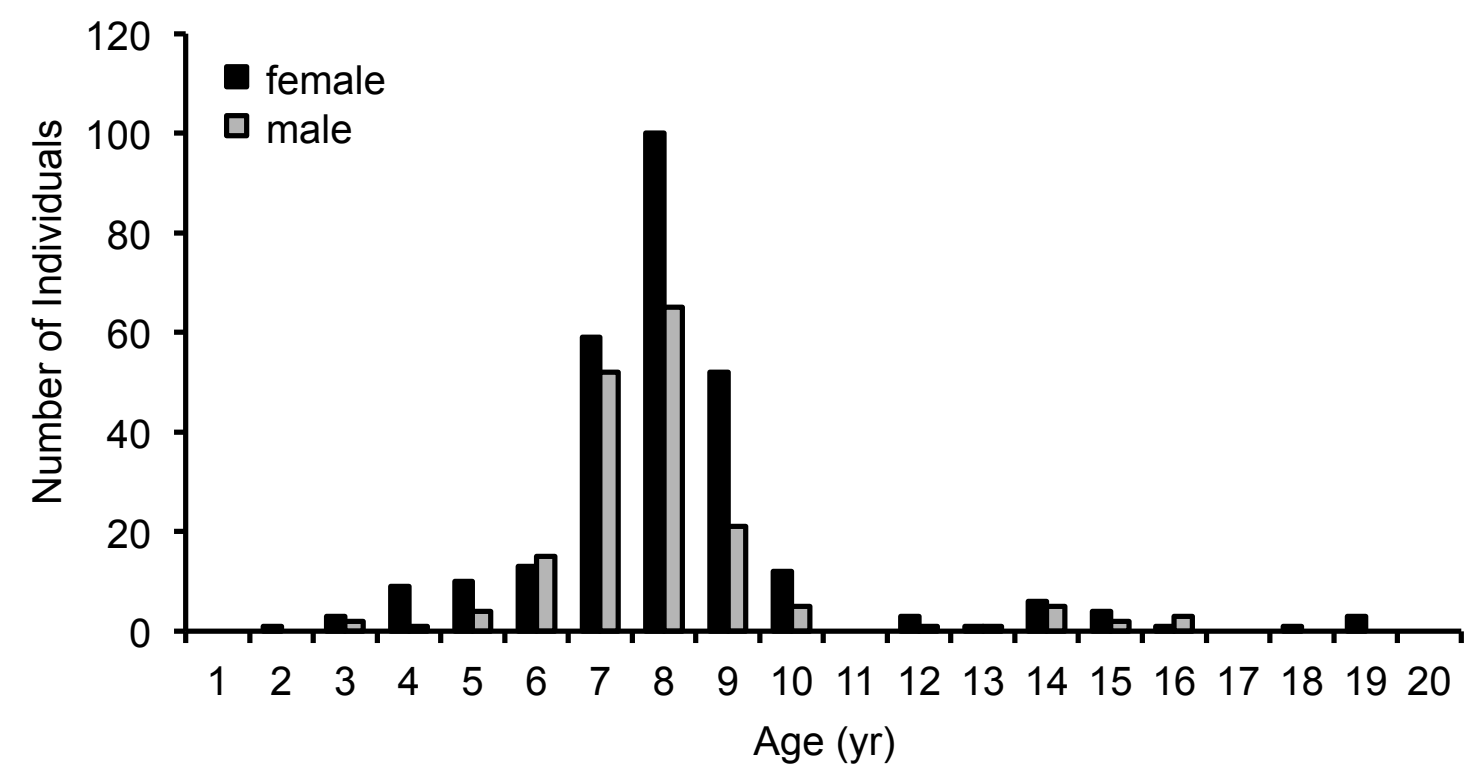

Figure 16. Age frequency distributions for central California Halibut, by sex. Black bars indicate females and gray bars indicate males.

\section{Growth Rates}

A total of 275 females and 177 males were used to estimate von Bertalanffy growth parameters for central California Halibut (fig. 17). For females, $\mathrm{L}_{\infty}$ and $\mathrm{K}$ were estimated at $1041 \mathrm{~mm}$ and 0.22 . For males, $\mathrm{L}_{\infty}$ and $\mathrm{K}$ were estimated at $824 \mathrm{~mm}$ and 0.25 . $\mathrm{L}_{\infty}$ and $\mathrm{K}$ were significantly different between the sexes, as indicated by non-overlapping 95\% confidence intervals (fig. 18). These results indicate greater maximum sizes and faster growth (i.e., larger size at age) of female California Halibut from this subset of fish collected north of Point Conception. 


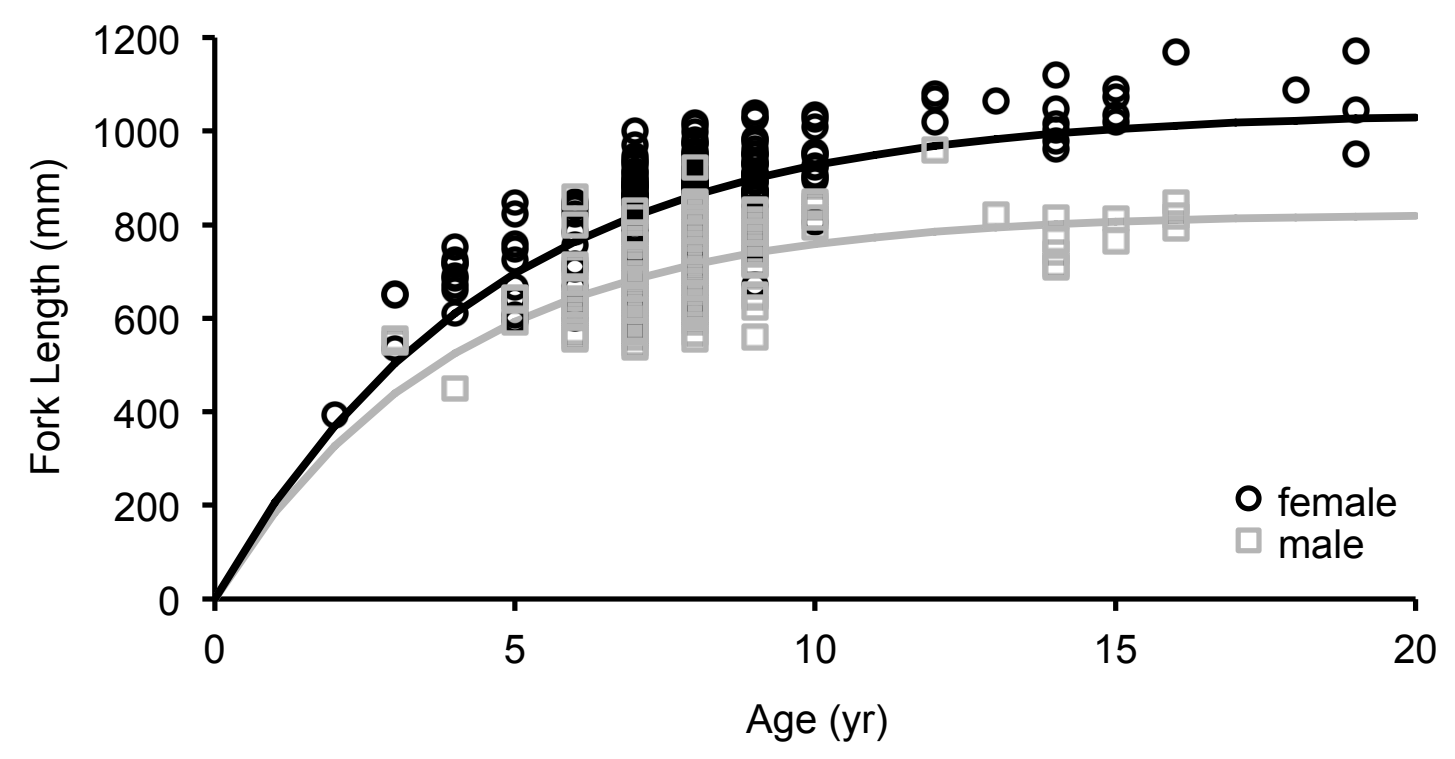

Figure 17. Length $(\mathrm{mm})$ at age $(\mathrm{yr})$ data for central California Halibut, by sex (Barnes data). Black circles denote females and gray squares denote males. Solid lines indicate predicted length-at-age, given the von Bertalanffy growth equations $L_{t}=1041\left(1-e^{-0.22(t+0)}\right)$ for females and $L_{t}=824\left(1-e^{-0.25(t+0)}\right)$ for males.

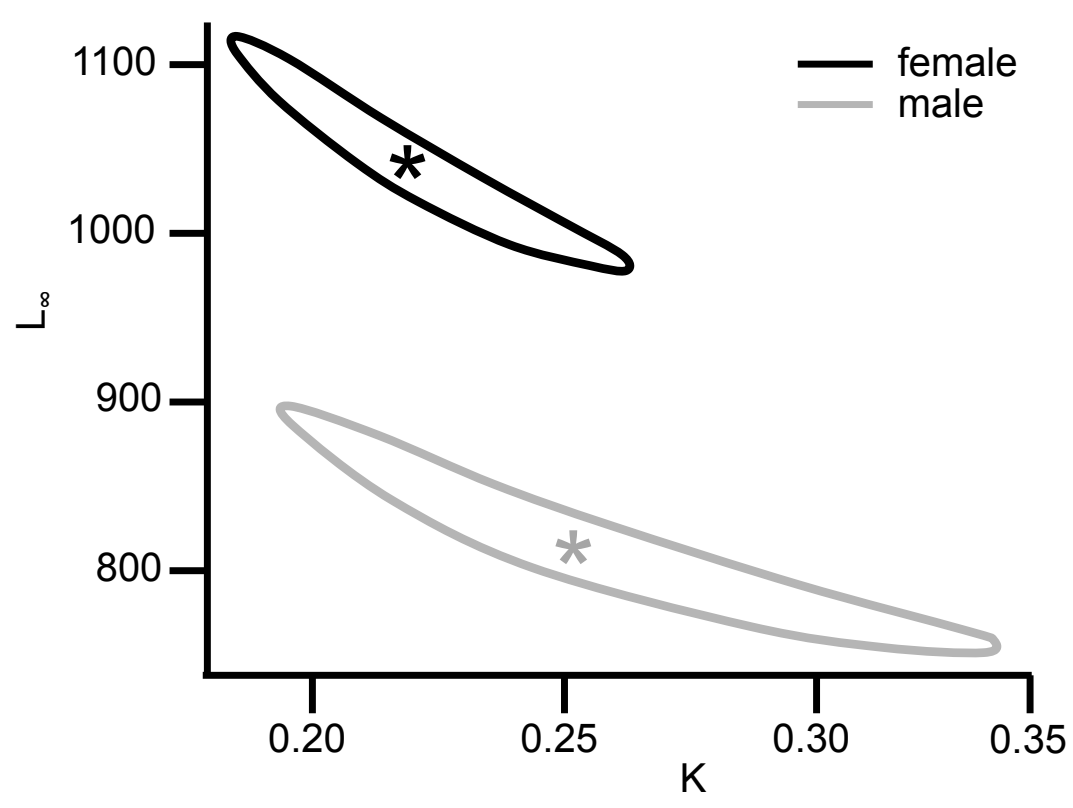

Figure 18. Von Bertalanffy growth parameters $\mathrm{K}$ and $\mathrm{L}_{\infty}$, denoted by asterisks (Barnes data). Ellipses indicate the $95 \%$ confidence intervals for female (black) and male (gray) California Halibut collected north of Point Conception. 
When merging my thesis data, which was collected from central California in 2012 and 2013, with CDFW-collected data from central and southern California between 2007 and 2014, sample sizes reached 1299 for central California and 760 for southern California. By estimating sex- and region-specific von Bertalanffy growth parameters, I found larger values of $K$ and smaller values of $L_{\infty}$ for central California Halibut (table 6). This translates to faster growth, but smaller maximum sizes for halibut collected north of Point Conception (figs. 19 and 20).

TABLE 6

Von Bertalanffy growth parameters $L_{\infty}$ and $K$ for California Halibut (Barnes and CDFW data), by sex and region. Standard errors are shown in parentheses.

\begin{tabular}{crrrr}
\hline & \multicolumn{2}{c}{ Female } & \multicolumn{2}{c}{ Male } \\
von Bertalanffy & central CA & southern CA & central CA & southern CA \\
\hline$L_{\infty}$ & $1049(15)$ & $1304(35)$ & $820(14)$ & $1048(60)$ \\
$K$ & $0.21(0.01)$ & $0.12(0.01)$ & $0.25(0.01)$ & $0.15(0.01)$ \\
\hline
\end{tabular}

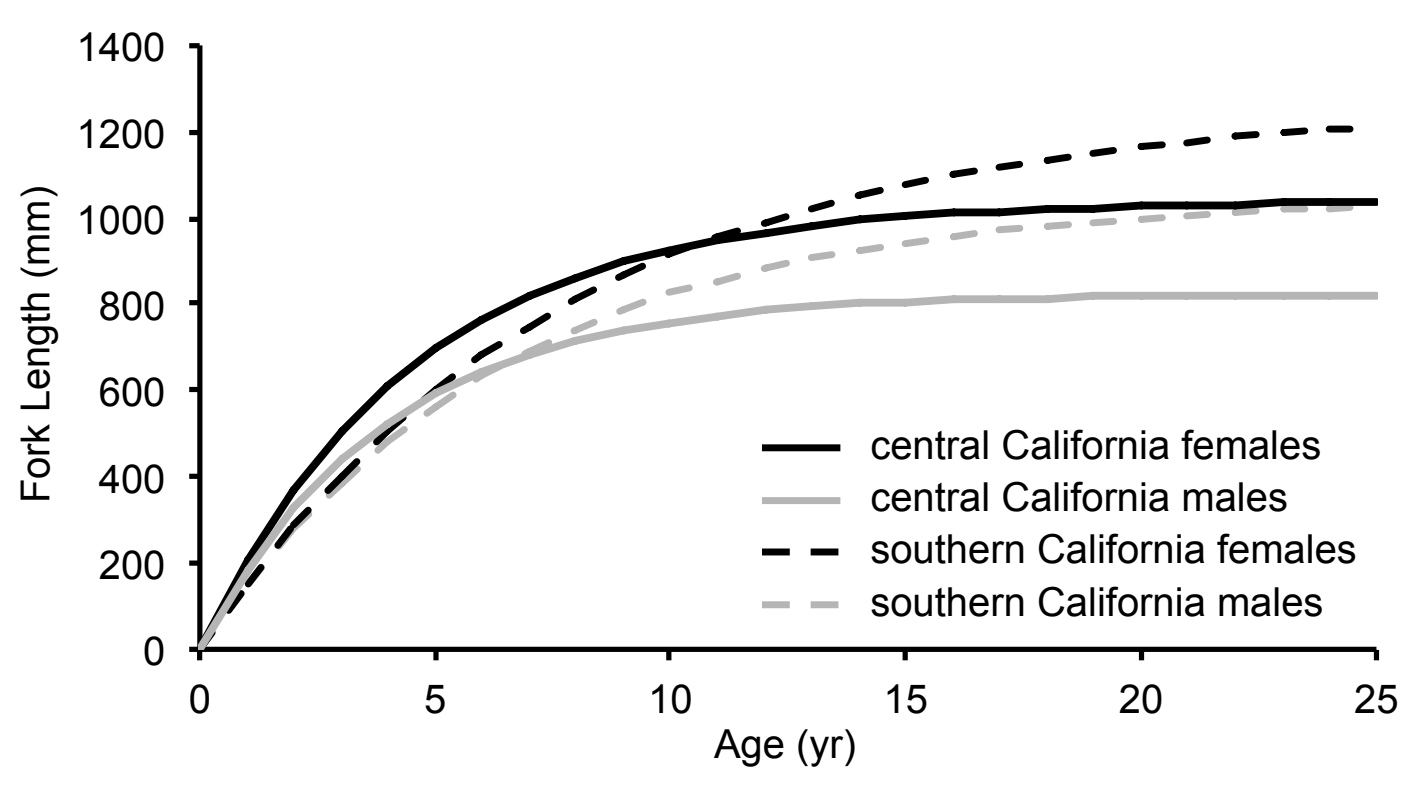

Figure 19. Von Bertalanffy growth curves for central (solid lines) and southern (dashed lines) California Halibut (Barnes and CDFW data). Expected lengths ( $\mathrm{mm}$ ) at age (yr) are shown in black for females and gray for males. 

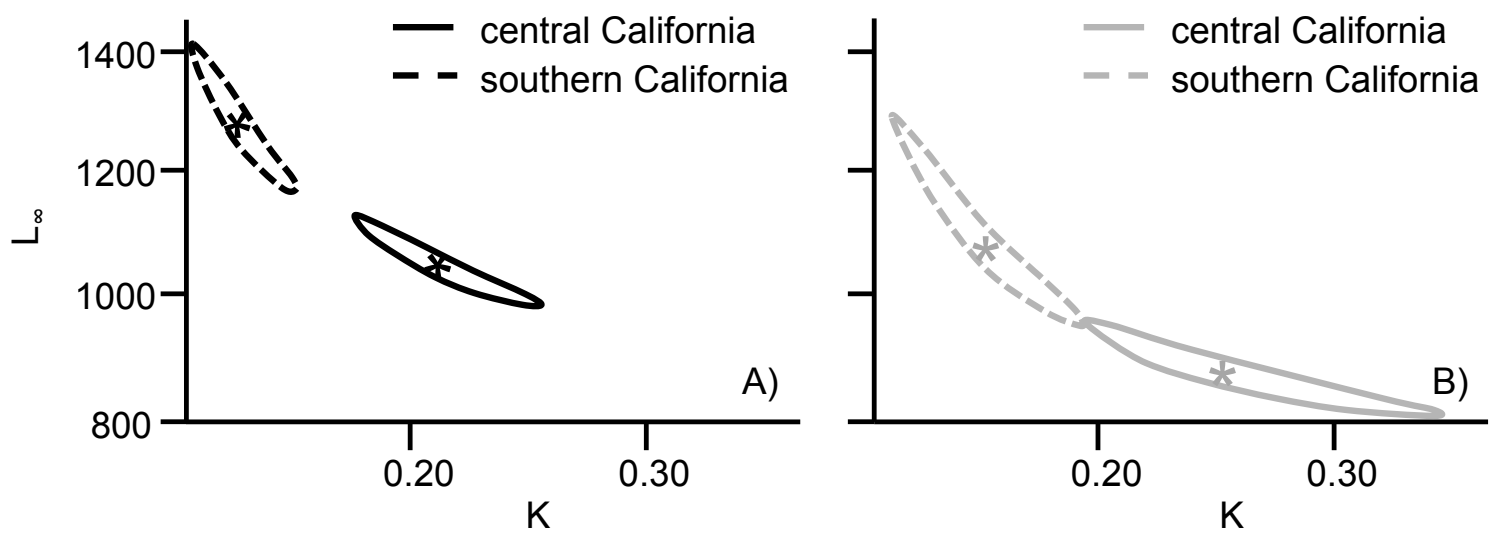

Figure 20. Von Bertalanffy growth parameters $\mathrm{K}$ and $\mathrm{L}_{\infty}$, illustrated by asterisks (Barnes and CDFW data). Ellipses denote the 95\% confidence intervals. Females are shown in black (left) and males are shown in gray (right). Solid ellipses indicate central California Halibut and dashed ellipses indicate southern California Halibut.

\section{Instantaneous Total Mortality}

Natural log-transformed age frequency data for central California Halibut were plotted for each sex (fig. 21). Catch curve analysis indicated that female halibut from central California experienced lower rates of instantaneous total mortality $(Z=0.32)$ than males $(Z=0.47)$ from the same region. Although statistical comparisons of slope (i.e., $Z$ or total mortality) yielded non-significant results $\left(F_{1,11}=0.655, p=\right.$ 0.435), graphical representations demonstrated a notable difference. No differences existed between the $y$-intercepts of males and females $\left(F_{1,12}=2.520, p=0.138\right)$, indicating no difference in relative abundance between female and male halibut collected off of central California in 2013. 


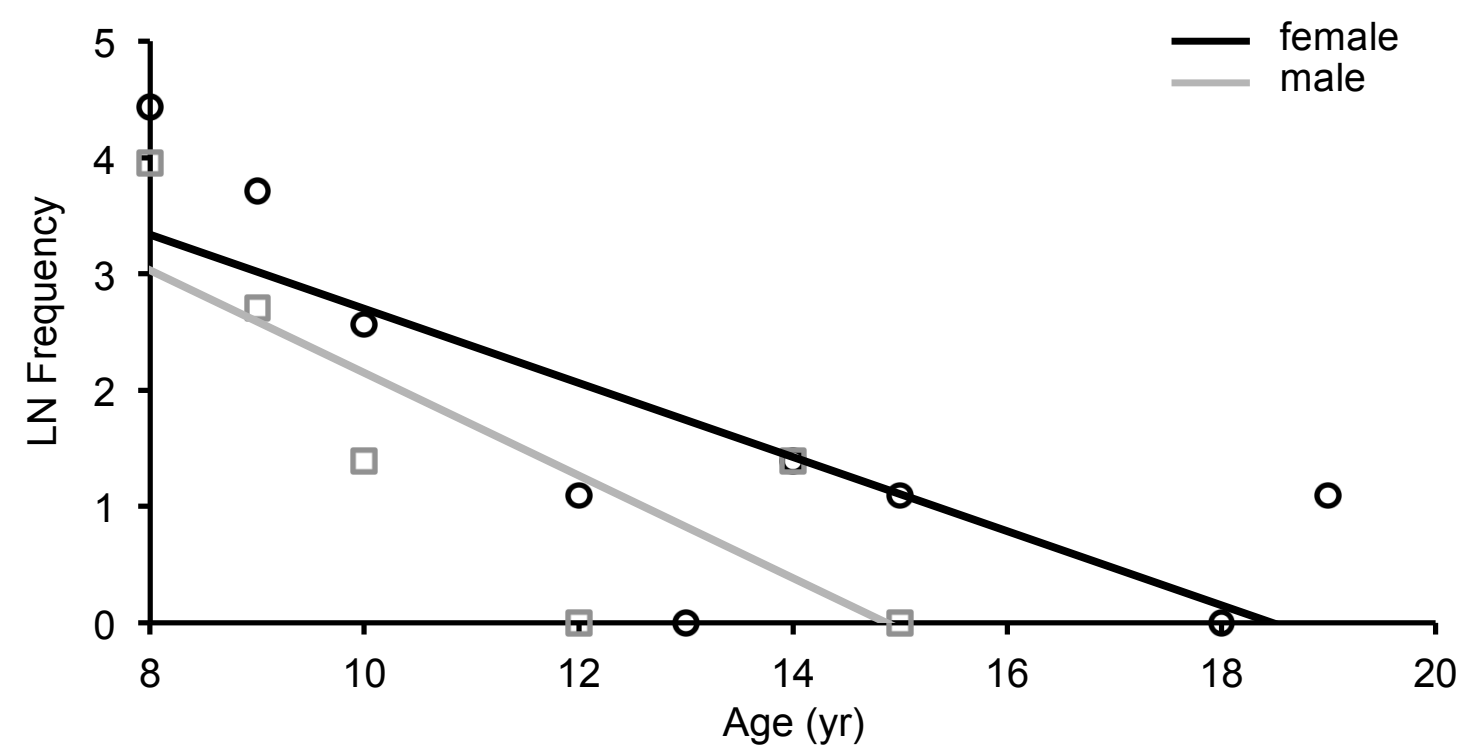

Figure 21. Instantaneous total mortality for central California Halibut caught in 2013 (Barnes data), given log-linear frequencies of age classes $\geq 8 \mathrm{yr}$. Female total mortality is represented by the equation $y=5.93-0.32 x\left(R^{2}=0.617, p=0.012\right)$ and male total mortality is represented by $y=6.83-0.47 x\left(R^{2}=0.710, p=0.035\right)$.

When comparing catch-at-age data using all fish (i.e., those collected for my thesis and by CDFW), I found no sex-based differences in total mortality for either region (central California: $F_{1,12}=0.166, p=0.691$; southern California: $F_{1,13}=0.006$, $p=0.937)$. Mathematical estimates of total mortality were very similar for males $(Z=0.35)$ and females $(Z=0.36)$ from southern California. Though non-significant, the calculation of total mortality for males from central California $(Z=0.42$, changed from 0.47 using only thesis data) was considerably greater than that for females $(Z=0.34$, changed from 0.32 using only thesis data) from the same region.

When comparing sex-specific estimates of total mortality by region, I found no significant difference $\left(F_{1,16}=0.035, p=0.854\right)$ between females from central and southern California and an apparent, but non-significant difference between males $\left(F_{1,9}=0.123, p=0.734\right)$ (fig. 22). Additionally, the number of southern California 
males sampled was statistically less (as indicated by differences in the y-intercept) than females from the same region $\left(F_{1,14}=69.150, p=0.004\right)$.

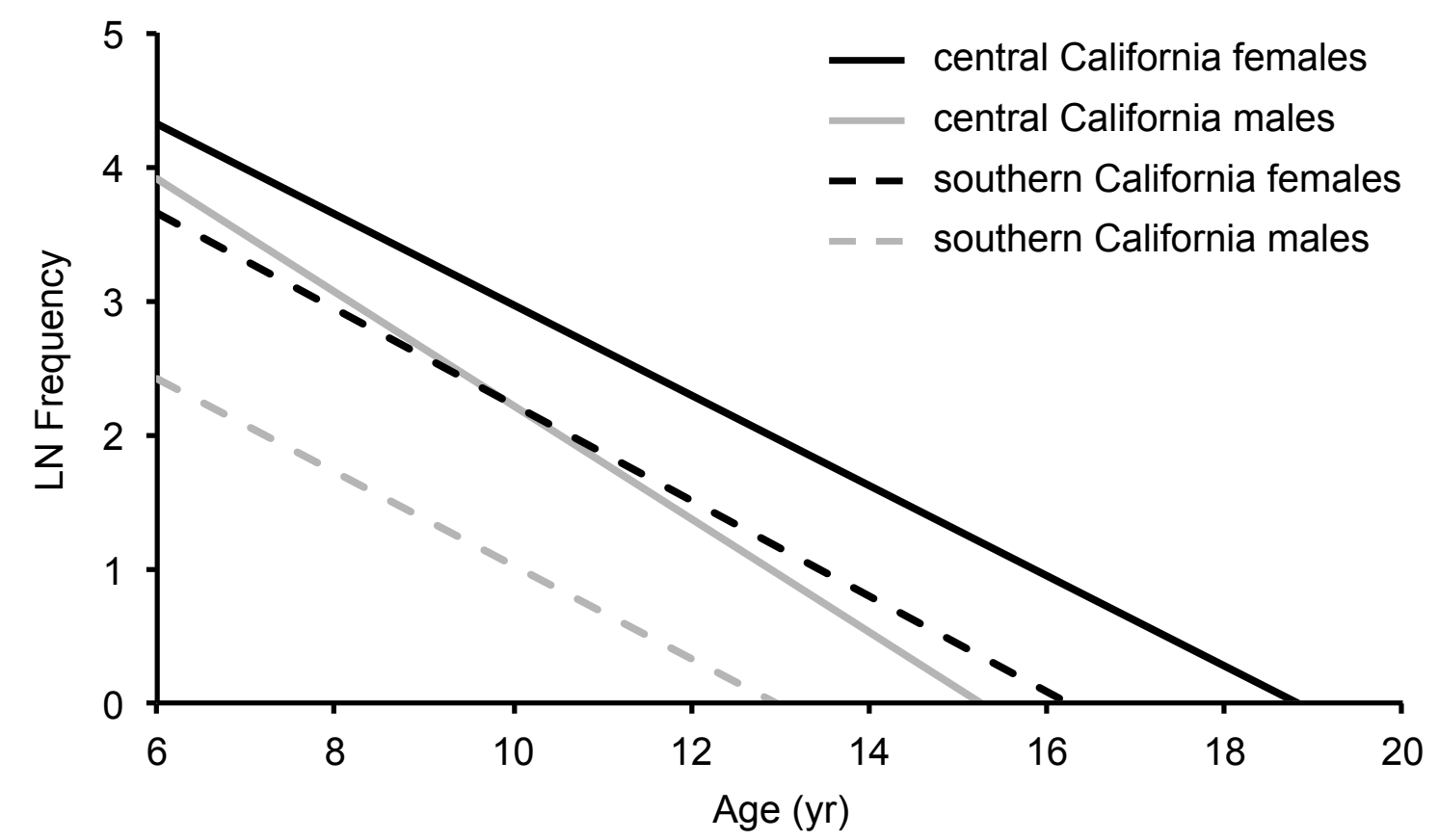

Figure 22. Instantaneous total mortality for California Halibut, Paralichthys californicus. Fish collected from central California in 2013 (Barnes and CDFW data) are represented by solid lines and fish collected from southern California in 2012 (CDFW data) are represented by dashed lines. Females are shown in black and males are shown in gray.

\section{Proportional Maturity}

Based upon macroscopic maturity assignments (i.e., presence of visible eggs or sperm indicating maturity and lack thereof denoting immaturity), $87.4 \%$ of central California females $(n=304)$ and $96.3 \%$ of central California males $(n=239)$ were considered reproductively mature at the time of capture. The remaining $12.6 \%$ of females $(n=44)$ and $3.7 \%$ of males $(n=3)$, termed immature, had either not yet reached sexual maturity or had reached maturity, but were not reproductively active at the time of capture. When assessing only legal-sized fish ( $\geq 559 \mathrm{~mm}$ fork length), 
$87.9 \%$ of females $(n=346)$ and $96.6 \%$ of males $(n=235)$ were considered mature. All mature, legal-sized males were also actively spawning (i.e., extruding milt) at the time of capture.

Because it is difficult to macroscopically discern immature individuals from those that are sexually mature, but reproductively inactive during the particular season (i.e., resting or skip spawning), histological analyses were used to determine precise maturity stages. The most advanced stage (MAS) of oocyte development, presence or absence of POFs, and rates of atresia were recorded for 206 female California Halibut (40 from 2012 and 166 from 2013). Microscopic maturity assignments resulted in 2.9\% ( $n=6)$ immature or resting, 9.7\% $(n=20)$ maturing, $50.5 \%(n=104)$ mature, $34.0 \%(n=70)$ spawning, and $2.9 \%(n=6)$ spent females. Once maturity stages were assigned microscopically, digital images of ovaries from the same fish were referenced to help describe macroscopic traits (table 7). 
TABLE 7

Simplified maturity staging system for female California Halibut, Paralichthys californicus. The microscopic terms used are consistent with Murua et al. (2003). MAS: most advanced stage of oocyte development.

\begin{tabular}{|c|c|c|}
\hline Maturity Stage & Macroscopic Characteristics & Microscopic Characteristics \\
\hline immature & ovaries small; pale in color & $\begin{array}{l}\text { MAS: chromatin nuclear or } \\
\text { perinucleolar }\end{array}$ \\
\hline maturing & ovaries deep orange in color & MAS: cortical alveoli \\
\hline mature & $\begin{array}{l}\text { ovaries yellow-orange in color; } \\
\text { oocytes visible to the naked eye; } \\
\text { red blood vessels branched }\end{array}$ & $\begin{array}{l}\text { MAS: yolk granule or } \\
\text { final maturation }\end{array}$ \\
\hline $\begin{array}{l}\text { spawning } \\
\text { (gravid or } \\
\text { running ripe) }\end{array}$ & $\begin{array}{l}\text { hydrated oocytes interspersed } \\
\text { throughout ovaries and may be } \\
\text { accumulated near vent }\end{array}$ & $\begin{array}{l}\text { MAS: hydrated; new }(<1 \mathrm{~d}) \\
\text { postovulatory follicles } \\
\text { (POFs) may be present }\end{array}$ \\
\hline spent & $\begin{array}{l}\text { oocytes visible to the naked eye; } \\
\text { histology necessary to assess } \\
\text { frequency of atresia }\end{array}$ & $\begin{array}{l}\text { MAS: yolk granule; } \\
\text { more than } 50 \% \text { vitellogenic } \\
\text { oocytes undergoing atresia }\end{array}$ \\
\hline resting & $\begin{array}{l}\text { ovaries small; deep orange in } \\
\text { color; white (i.e., empty) blood } \\
\text { vessels present }\end{array}$ & MAS: perinucleolar \\
\hline
\end{tabular}

\section{Characterization of the Summer Spawning Season}

Spawning females were found from June 17 to September 6 in 2012 and June 22 to September 5 in 2013. This demonstrated a summer spawning duration of $82 d$ in 2012 and $76 d$ in 2013. By averaging these two years, the central California Halibut summer spawning season was estimated at $79 \pm 3 \mathrm{~d}$, from mid June to early September.

In addition to using the incidence of spawning females as an indicator of summer spawning duration, relative proportions of each maturity stage provided further support of temporally-influenced spawning activity in 2013 (fig. 23). From June to August, proportional maturity stages remained relatively constant, with 
mature stages representing $0.55(n=76)$ and spawning stages representing 0.37 $(n=51)$ of females sampled. However, by the end of August and into September, spent stages made up increasing greater proportions ( 0.12 and 0.33 , respectively), indicating a cessation of spawning activity and conclusion of the summer spawning season. Relatively few individuals were caught before June, when summer spawning is thought to have commenced, or after mid-September, when spawning activity appeared to be in decline.

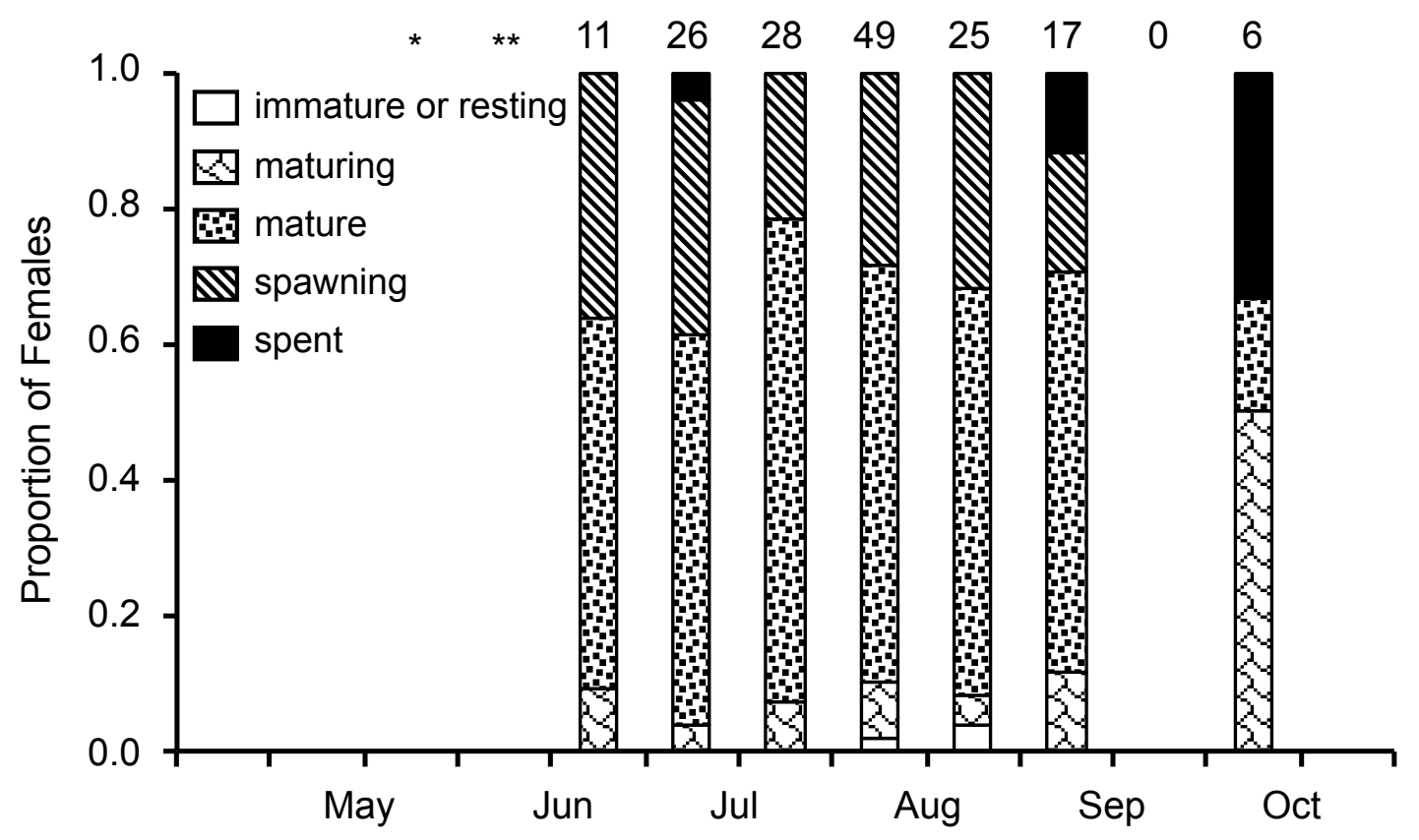

Figure 23. Proportions of females sampled in central California (2013), by microscopic maturity stage and month. Sample sizes are indicated above each bar, which represents a $14 \mathrm{~d}$ sampling period. ${ }^{*}=$ one mature fish sampled; ${ }^{* *}=$ two maturing fish sampled.

Temporal variations in gonadosomatic index (GSI) of female California Halibut also supports the estimated duration of spawning activity in 2013. In the beginning of June, GSI for mature and spawning females was relatively low, ranging from 2.0 to 4.0 . From mid-June to the end of July, mean GSI for the same maturity 
stages reached values greater than 4.0. An increase in GSI (>6.0) was observed during the first two weeks in July, indicating a peak in reproductive effort during that time period. By August, mean GSI of mature and spawning females began to decrease again, demonstrating a reduction in spawning activity toward the end of summer. The incidence of spent females with GSI values less than 2.5 at the end of August and beginning of September indicated relatively little investment in reproduction and a cessation of spawning activity for sampled fish (fig. 24). Mean GSI for females categorized as immature, maturing, or resting at the time of capture did not change throughout the sampling period.

Though hepatosomatic index (HSI) was calculated throughout the 2013 summer season, no clear pattern was evident to support seasonal changes for female California Halibut (fig. 25). 


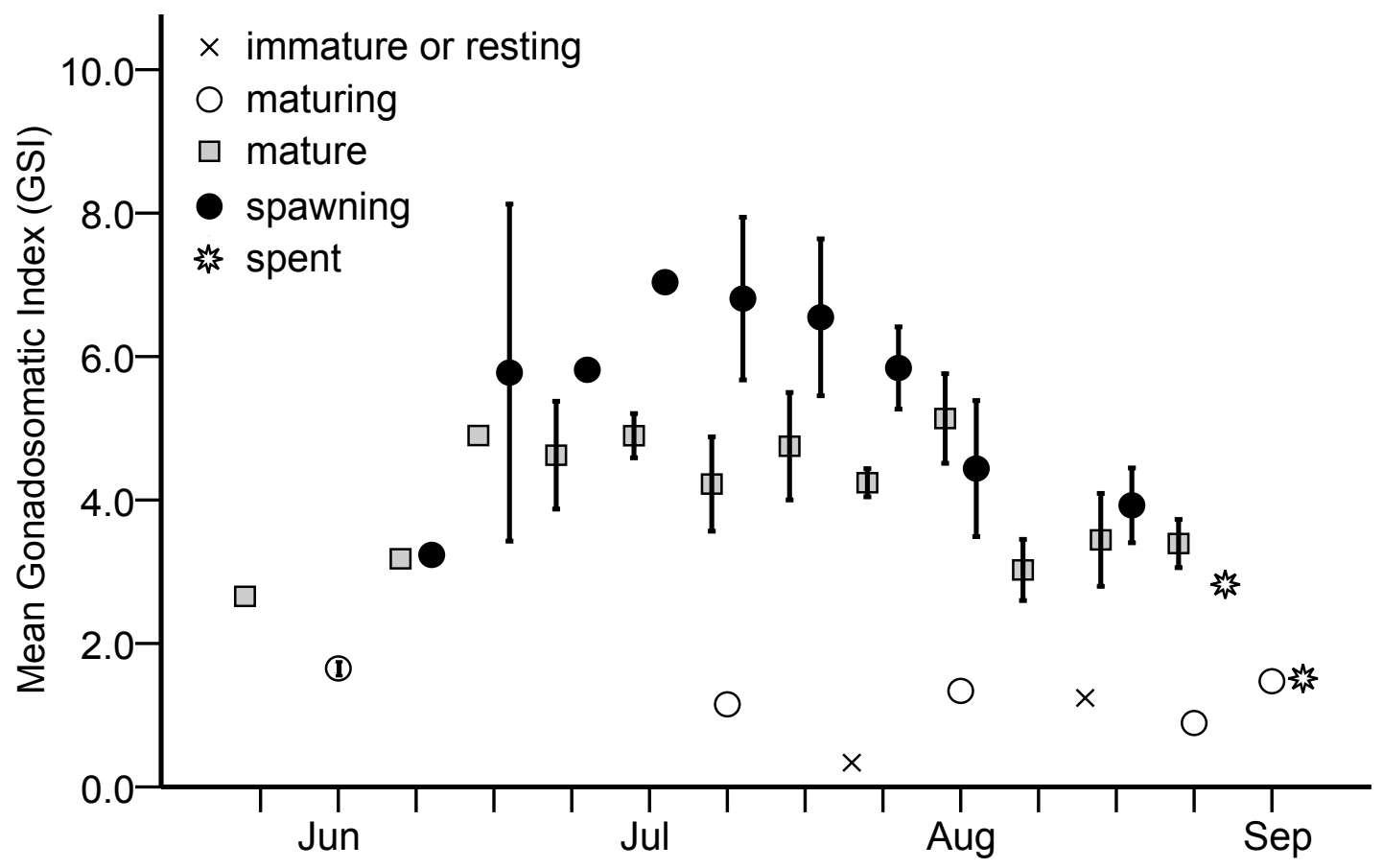

Figure 24. Mean gonadosomatic index for female California Halibut caught in central California (2013), by week and maturity stage. Error bars denote one standard error.

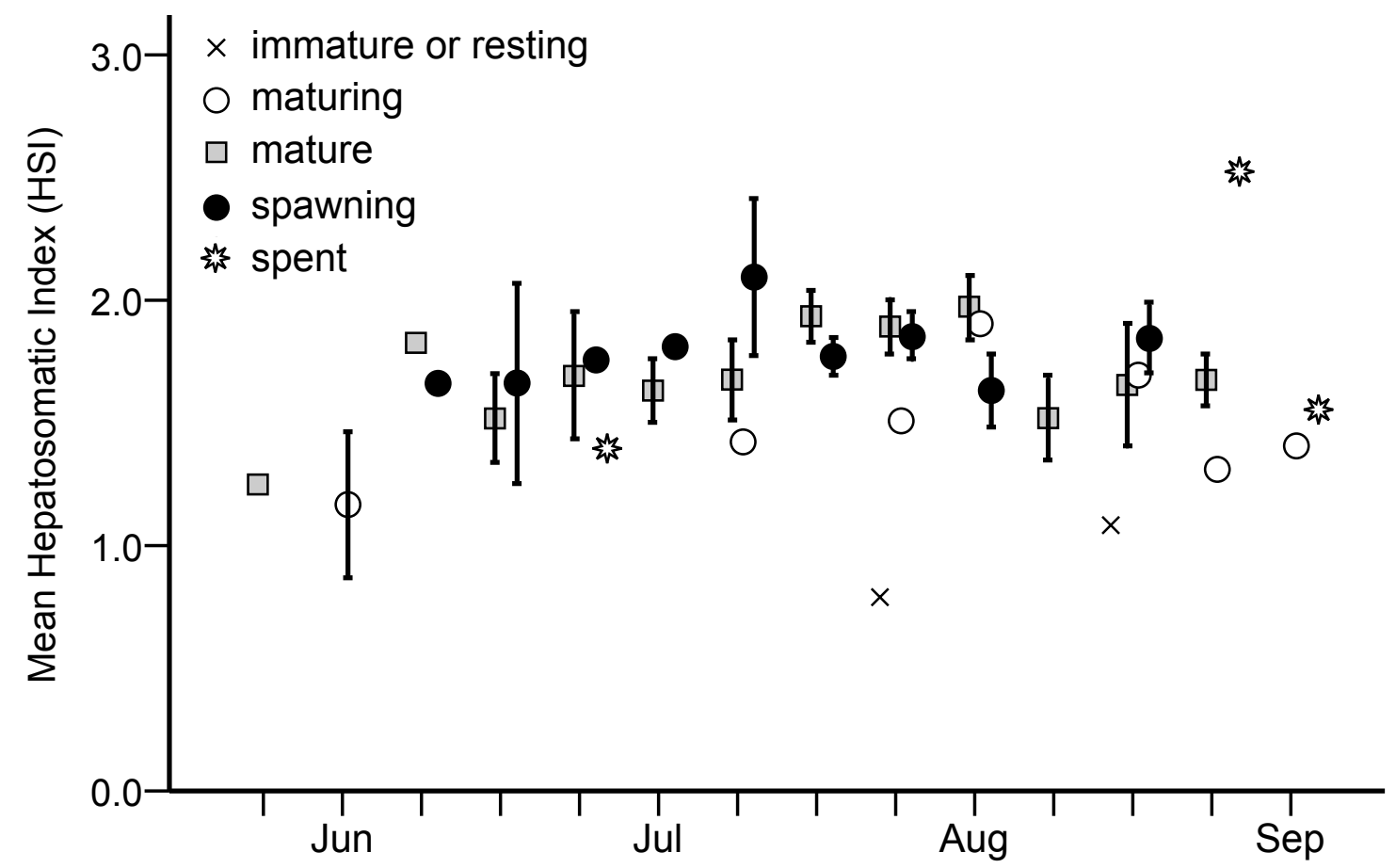

Fig. 25. Mean hepatosomatic index for female California Halibut caught in central California (2013), by week and maturity stage. Error bars denote one standard error. 
Daily Spawning Fraction, Interspawning Interval, and Spawning Frequency

The mean daily spawning fraction (s) for female California Halibut (i.e., those with POFs estimated to be one day old) was calculated at $0.33(n=1)$ for 2012 and $0.29 \pm 0.1(n=21)$ for 2013 . The mean daily spawning fraction for both years combined was $0.31 \pm 0.0(n=22)$. The interspawning interval $\left(\frac{1}{s}\right)$ was $3.0 d$ in 2012 and $3.4 \mathrm{~d}$ in 2013. For both years combined, the interspawning interval was $3.2 \mathrm{~d}$. Finally, the spawning frequency (f) for central California Halibut was determined by dividing the duration of the summer spawning season by the interspawning interval (table 8). In 2012, the spawning frequency was approximately 27 events per season, whereas the spawning frequency in 2013 was 22 events per season. The mean for both years combined was 25 events per summer spawning season. Due to a sample size of one day in 2012, no statistical comparisons of year were made.

TABLE 8

Summary of reproductive parameters for female California Halibut, by year. Sample size $(n)$ indicates the number of days used in each calculation ( $\geq 3$ reproductively active females were required for inclusion).

\begin{tabular}{lccc}
\hline & $\begin{array}{c}2012 \\
(\mathrm{n}=1)\end{array}$ & $\begin{array}{c}2013 \\
(\mathrm{n}=21)\end{array}$ & $\begin{array}{c}\text { Both Years } \\
(\mathrm{n}=22)\end{array}$ \\
\hline Duration of Spawning Season (d) & 82 & 76 & 79 \\
No. Spawning Females & 2 & 29 & 31 \\
Total No. Reproductive Females & 3 & 100 & 103 \\
Mean Spawning Fraction (SE) & $0.33(\mathrm{~N} / \mathrm{A})$ & $0.29(0.05)$ & $0.31(0.02)$ \\
Interspawning Interval (d) & 3.0 & 3.4 & 3.2 \\
Spawning Frequency & 27 & 22 & 25 \\
\hline
\end{tabular}




\section{Batch Fecundity}

Because California Halibut are multiple spawners for which the time of day that batches of eggs are released is unknown, batch fecundity estimates were limited to spawning females exhibiting GSIs within one standard deviation of the mean. In theory, this eliminated individuals that had recently spawned a large proportion of eggs and/or were very early in the hydration process, thereby possessing far fewer hydrated oocytes than would have been produced for the spawning event in progress.

Among the 40 individuals that met the above criteria, batch fecundity ranged from 39,681 to $1,474,584$ oocytes (appendix II). The mean batch fecundity was $498,830 \pm 44,163$. However, this included estimates from female California Halibut ranging in fork lengths from 685 to $929 \mathrm{~mm}$ and capture dates throughout the reproductive seasons of 2012 and 2013 . When considering only spawning females within one standard error of the mean fork length $(850 \mathrm{~mm})$, mean batch fecundity was estimated at $599,378 \pm 67,204(n=3)$. This is considered a conservative estimate of batch fecundity for an average-sized female, as the elapsed time between hydration and spawning is likely on the order of hours (Hunter et al. 1985; Kurita et al. 2011). Therefore, the quantity of hydrated oocytes for a spawning female is highly susceptible to timing of capture and is likely less than the ephemeral absolute maximum (e.g., if spawning is initiated at night, females captured in the early morning would likely possess relatively few hydrated oocytes; fig. 26). 


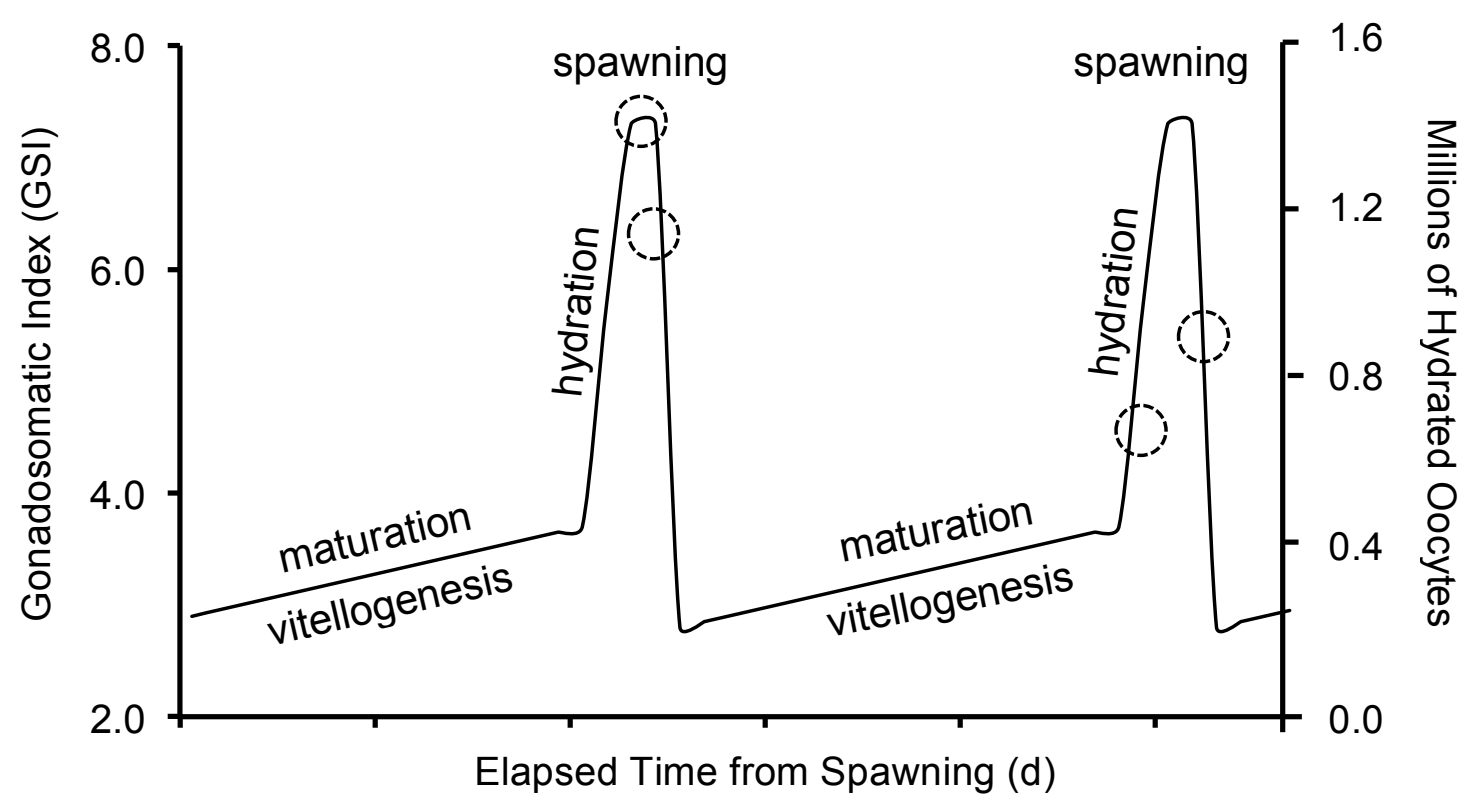

Figure 26. Maturation cycle of a California Halibut female throughout a given spawning season [based upon gonadosomatic index (GSI), batch fecundity (millions of hydrated oocytes), and interspawning interval (i.e., elapsed time from spawning in days)]. Dashed circles illustrate hypothetical sampling events, with the ideal capture time located at peak values. Figure adapted from Hunter et al. (1985).

To evaluate the relationship between fork length $(\mathrm{mm})$ and batch fecundity, I plotted data from female California Halibut considered to be in the late hydration phase of spawning at the time of capture (fig. 27). Curve estimation software determined that the best-fit model was the power function $F=3.65 \times 10^{-12} L^{5.86}$ $\left(R^{2}=0.480, F_{1,15}=13.837, p=0.002\right)$. As with many other fish species, batch fecundity exponentially increased with increasing length.

The procedures detailed above were also used to evaluate the relationship between batch fecundity and time (represented as Julian days) in 2013. A significant relationship existed for females in the late hydration and actively spawning phases, given the quadratic function $y=-502 x^{2}+214759 x-22307777$ $\left(R^{2}=0.258, F_{2,24}=4.183, p=0.028\right.$; fig. 28). This relationship demonstrated that 
the largest batch fecundities were found in the beginning of August (around Julian day 215), which corresponds with the approximate middle of the summer spawning season previously described. Conversely, the smallest batch fecundities were found in the beginning of July and very end of August, approaching the beginning and end of the spawning season.

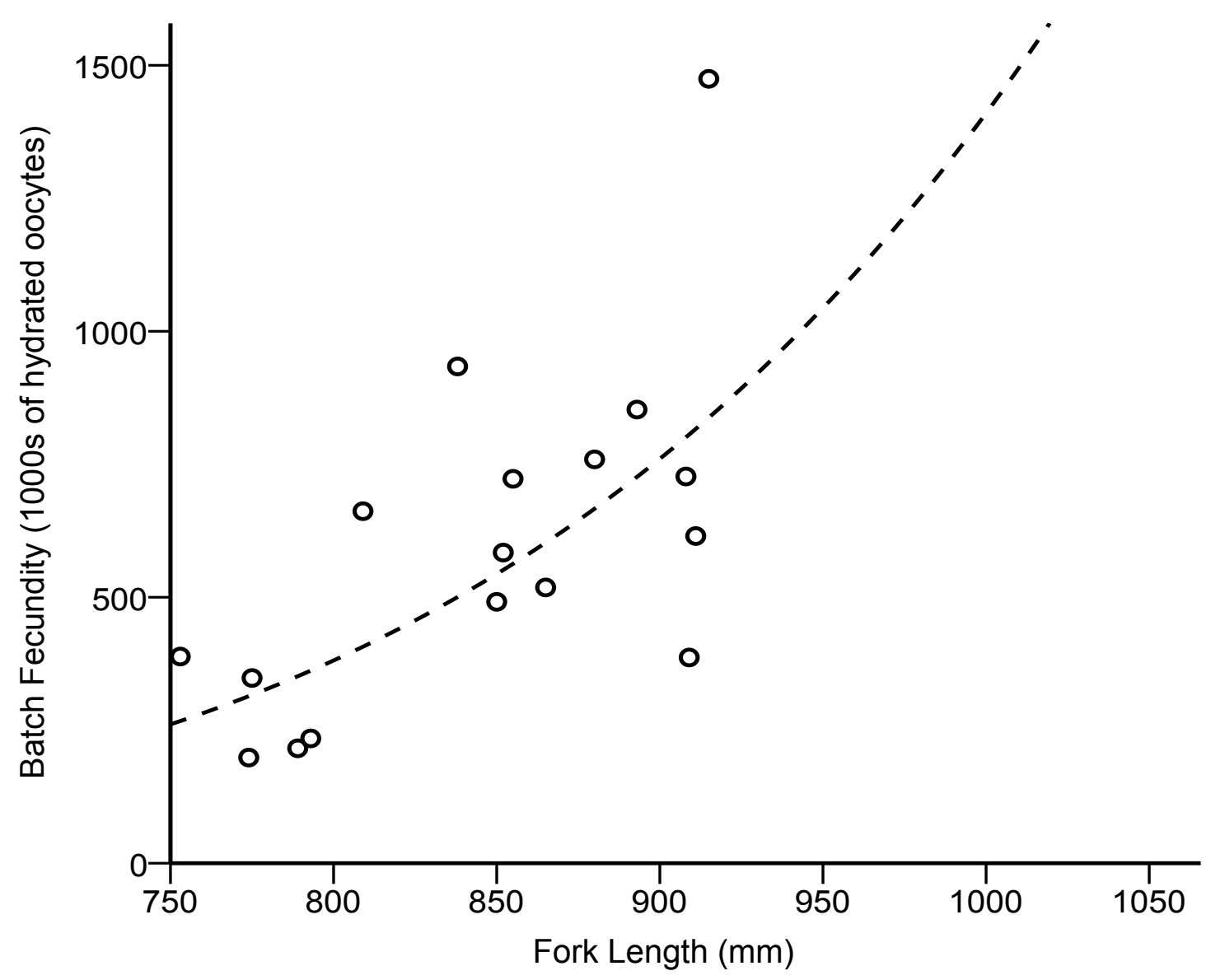

Figure 27. Relationship between fork length $(\mathrm{mm})$ and batch fecundity (thousands of eggs) for female California Halibut in the late hydration phase of spawning (i.e., presence of hydrated oocytes, no final maturation stage or post ovulatory follicles). The dashed line indicates the expected batch fecundity at length $(n=17)$. 


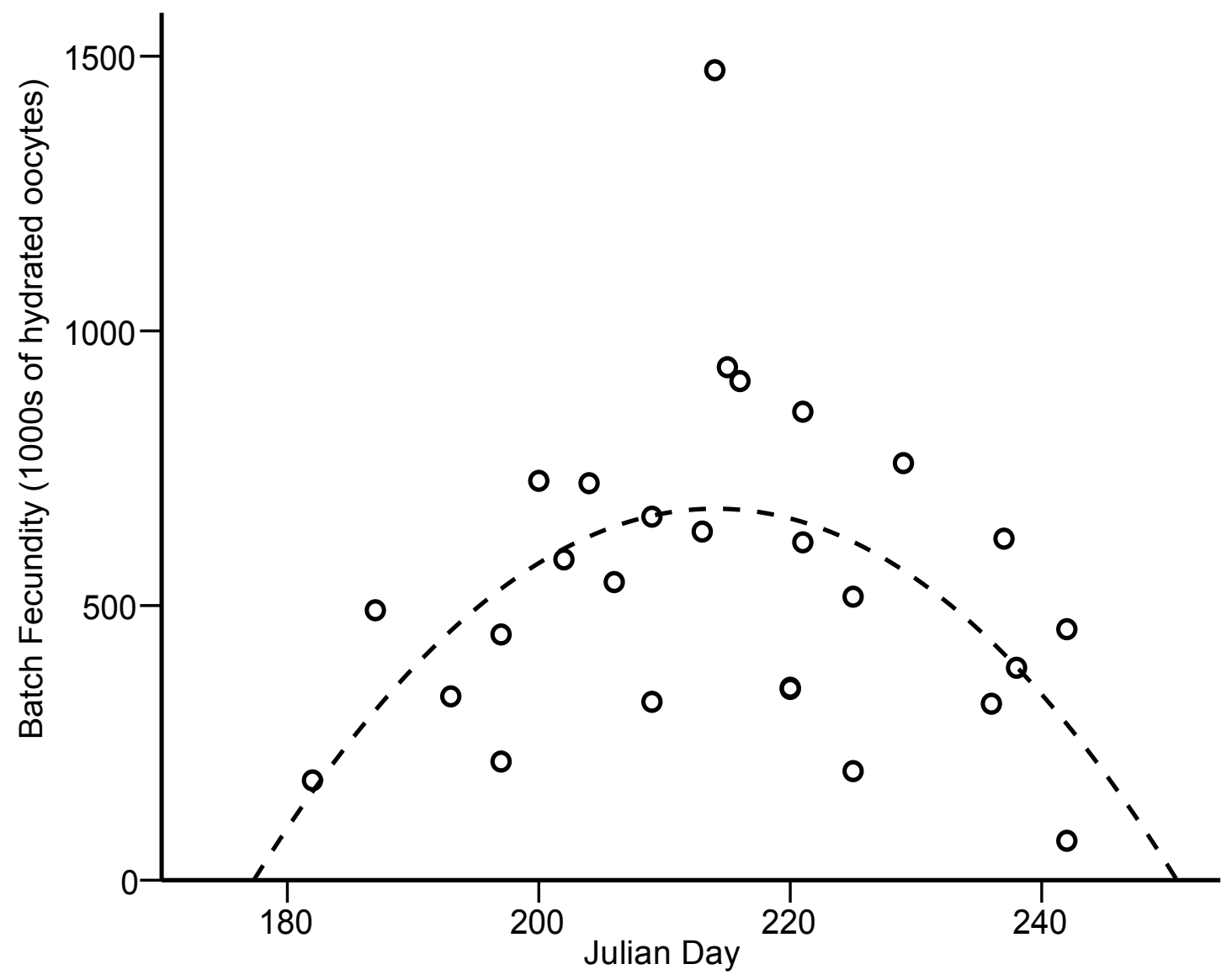

Figure 28. Batch fecundity (thousands of hydrated oocytes) of California Halibut, by Julian day (2013). Circles represent estimates for spawning females in the late hydration (i.e., presence of hydrated oocytes, no final maturation stage or new postovulatory follicles) or actively spawning (i.e., presence of hydrated oocytes and new postovulatory follicles) phases $(n=33)$. The dashed line indicates the expected batch fecundity at length, given the equation $F=-8.3 \times 10^{7}+1.6 \times 10^{6} \mathrm{~L}-84.1 \mathrm{~L}^{3}$.

\section{Reproductive Potential}

The seasonal reproductive potential of an average-sized California Halibut (i.e., $850 \mathrm{~mm}$ ) was determined by multiplying a mean batch fecundity of 599,378 eggs and spawn frequency of 25 events per season. This produced a seasonal fecundity of $14,984,450$ eggs (table 9 ). Again, this is likely a conservative estimate 
because it is based upon opportunistic sampling and an unknown spawning behavior (e.g., timing of broadcast events) for the study species.

TABLE 9

Parameters used to calculate seasonal reproductive potential of an average-sized central California Halibut female.

\begin{tabular}{lc}
\hline Reproductive Parameter & Value \\
\hline interspawning interval & $3.2 \mathrm{~d}$ \\
duration of summer spawning season & $79 \mathrm{~d}$ \\
spawning frequency & 25 events per season \\
batch fecundity & 599,378 eggs per event \\
potential seasonal fecundity & $14,984,450$ eggs per season \\
\hline
\end{tabular}

\section{DISCUSSION}

A stock assessment is a systematic procedure in which fishery scientists estimate and forecast biological parameters such as population size, growth, recruitment, and mortality (both natural and fishing). Contemporary stock assessment models also include information about environmental variation, uncertainty in data or model outcomes, and levels of risk associated with various predictions (e.g., Garcia et al. 1999; Patterson 1999). Resource managers utilize the results of an assessment to balance biological and socioeconomic objectives while making regulatory decisions about allowable catch, fish sizes, gear types, effort restrictions, and spatiotemporal closures (Rice et al. 2005). Because regulatory measures affect the biological parameters used in stock models, a positive feedback loop exists between fishery assessment and management. Therefore, it is essential that biological data adequately represent the fishery in 
question, both in time and in space, so that the effectiveness of management actions can be appropriately evaluated.

However, a number of species (e.g., many flatfishes from the order Pleuronectiformes) are managed as complexes rather than individual component species (e.g., Wilderbuer and Nichol 2013). Represented by 14 different families, 121 genera, and 716 species, flatfishes exhibit substantial variation in growth (i.e., maximum sizes from $2 \mathrm{~cm}$ to over $2 \mathrm{~m}$ and $300 \mathrm{~kg}$ ), reproductive strategies (e.g., total vs. batch spawning, pelagic vs. demersal eggs), spawning durations (i.e., 2 months to year-round), and longevity (i.e., 1.5 to $60 \mathrm{yr}$ ) (Gibson 2005). Additionally, widespread distributions and subsequent differences in environmental (e.g., temperature, irradiance) and/or ecological (e.g., prey availability, predation) characteristics lead to intraspecific variation in flatfish life history traits (e.g., Witthames et al. 1995; Spencer 2008; Nissling and Dahlman 2010).

Many large-tooth flounders (family Paralichthyidae) have been shown to exhibit spatiotemporal differences in growth and reproduction. There is evidence that the Southern Flounder, Paralichthys lethostigma, grows at different rates along the northwestern Atlantic and in the Gulf of Mexico (Etzold and Christmas 1979; Nall 1979). Latitudinal trends have also been observed in the maturation rates of Japanese Flounder (Paralichthys olivaceus), with fish becoming reproductive at earlier ages in more southern locations (Yoneda et al. 2007). Because of such support for spatially explicit life history traits, questions have been raised about the potential for multiple populations of flatfishes with widespread distributions (e.g., 
Summer Flounder, Paralichthys dentatus, Packer et al. 1999), leading to discussions about whether or not these species should continue to be managed as single stocks.

Although Maunder et al. (2011) defined two separate stocks of California Halibut, limited life history data forced assessment scientists to fix many of the central stock model parameters based upon data collected from southern California. Because spatial complexity and fine-scale environmental variability generate differences in key biological processes (e.g., growth rates, timing of maturation, reproductive potential, population abundance, mortality) within continuously distributed species, CDFW recognized a need to collect life history data for California Halibut at multiple spatial scales (CDFW 2011b). Model sensitivity to regional estimates of natural mortality, average length of the oldest fish, and relative abundance made this especially important, as outputs from the assessment are used to inform policy decisions.

My masters thesis research, which provides a detailed account of sex-specific growth, reproduction, and mortality, attempts to enhance our understanding of localized population dynamics and better inform resource managers about the spatial structure of California Halibut life history. Although similar studies have been conducted, my work uniquely provides comprehensive data from a wide size range of fish, including older, larger individuals from central California. This is also the first study to estimate batch fecundity and seasonal reproductive activity of wild-caught California Halibut.

The sex ratio calculated for central California Halibut as part of this work $(1.4: 1)$ differs from previous estimates for juveniles caught in Mexico (1:2.2, 
Hammann and Ramirez-Gonzalez 1990) and slightly smaller adults in central (1.1:1) and southern (1:2.2) California (MacNair et al. 2001). Similarly sized halibut from southern California have exhibited a sex ratio of 4.3:1 (Sunada et al. 1990), which matches my calculation made using CDFW-sampled fish between 2007 and 2014 . The disproportionate sex ratios between central and southern California may be due to sex- and region-based differences in natural or fishing mortality. However, additional research is necessary to elucidate potential mechanisms, which can also include variation in habitat use by sex and ontogenetic stage.

In ageing thesis-collected fish from central California, 431 blind-side otoliths were evaluated. An additional 26 (5.7\%) eyed-side otoliths replaced blind-side otoliths that were missing, broken, or unusable due to crystallization around the margin. Without comparing reads from blind- and eyed-side otoliths of the same fish, potential differences in interpretation or bias remain unknown. Instead, I made the assumption that there was no difference in age determinations of blind- and eyed-side otoliths, as long as readability generated agreement between at least two independent readers.

Age frequency distributions of central California Halibut indicated a pulse in recruitment between 2004 and 2006 . The presence of these exceptionally strong year-classes, when combined with weak 2000 to 2002 year-classes, demonstrates considerable variability in California Halibut recruitment. The strong 2004 to 2006 year-classes coincided with periods of relatively weak upwelling, whereas the weak 2000 to 2002 year-classes coincided with periods of strong, persistent upwelling in central California (Caselle et al. 2010). This suggests that upwelling may have a 
negative effect on central California Halibut recruitment, due to larval advection offshore, an intolerance to cold sea surface temperatures at early life history stages, increased predation from upwelling-favorable species, or some other factor. Additionally, prolonged periods of above average sea surface temperatures may enable greater egg production of adults and larval survivorship for this warmtemperate, subtropical species. However, additional research is necessary to evaluate cause-and-effect relationships between California Halibut recruitment and localized environmental conditions.

Consistent with existing scientific literature, female California Halibut sampled as part of this study grew faster and to larger sizes than male conspecifics (MacNair et al. 2001). However, regional comparisons, which included CDFW-collected length-at-age data (2007 to 2014), showed that central California Halibut grew faster, but reached smaller maximum sizes than fish from southern California. This contradicts results from MacNair et al. (2001), which showed larger maximum sizes for California Halibut collected north of Point Conception. The growth parameters estimated herein likely provide more realistic predictions of length-based age than those provided by MacNair et al. 2001 due to the fact that $t_{0}$ was fixed at zero and larger (i.e., older) individuals were sampled more adequately.

Fixing $t_{0}$ at zero forced the von Bertalanffy growth curves through the origin. Without doing so and not having properly sampled new recruits, a calculated $t_{0}$ would have produced unrealistic estimates of length-at-age for younger fish [e.g., predicted length of approximately $200 \mathrm{~mm}$ age for an zero fish, as in MacNair et al. (2001)]. Sampling more of the larger, older individuals also produced estimates of $L_{\infty}$ that 
were anchored by data as opposed estimates that were more predictive because of sampling efforts that focused on collecting smaller, younger individuals (MacNair et al. 2001).

In addition to enabling a characterization of California Halibut growth, age data provided sex-structured estimates of instantaneous total mortality $(Z)[Z=$ fishing mortality $(F)+$ natural mortality $(M)$ ]. Maunder at al. (2011) incorporated $M$ values of 0.2 for females and 0.3 for males into both the central and southern California stock models. Without estimates of natural mortality available for California Halibut at the time of assessment, these values were based upon information from Summer Flounder (longevity of $15 \mathrm{yr}$ ). Subsequent to the stock assessment, total mortality estimates for southern California Halibut females were made available $[Z=0.53$ from Sunada et al. (1990) data and $Z=0.36$ from CDFW unpublished data). My estimates of $Z$ for central $(0.34$ for females and 0.42 for males) and southern ( 0.36 for females and 0.35 for males) California Halibut could be used in conjunction with a tagging study (estimating $F$ ) to better parameterize region-specific M. Because the stock models used for California Halibut are sensitive to M (as indicated by Maunder et al. 2011), empirically determined natural mortality would likely provide more reliable outputs than when $\mathrm{M}$ is assigned based upon a congener from the east coast of the United States.

In determining maturity for 346 female and 235 male legal-sized California Halibut, I found that the vast majority of males (i.e., $96.6 \%$ ) and females (87.9\%) sampled were reproductively active at the time of capture. Additionally, most of the inactive females were considered temporarily maturing or resting, and had likely 
spawned earlier in the season of capture or during previous years. This information indicates that the legal "population" of California Halibut north of Point Conception is primarily reproductive. Additionally, this suggests that the minimum size limit of $559 \mathrm{~mm}$ (fork length) is effective at protecting immature fish and allowing central California Halibut to reproduce at least once (and probably many more times) before being harvested.

California Halibut have been described as exhibiting year-round reproduction, with peak activity between late winter and spring in southern California (Haaker 1975; Lavenberg et al. 1986; Love and Brooks 1990). Recent ichthyoplankton surveys (CalCOFI unpublished data, 1980 to 2011) have indicated that the greatest larval abundances of California Halibut are found in April (southern California and Mexico), June (Mexico), and July (southern California). Given a larval duration of 20 to $29 \mathrm{~d}$, spawning effort (represented by applying a $30 \mathrm{~d}$ correction to larval density data) would be expected to be greatest in March (southern California and Mexico), May (Mexico), and June (southern California). Although CalCOFI data effectively demonstrate spawning patterns of California Halibut south of Point Conception, relatively infrequent and offshore surveys north of Point Conception make comparisons among Mexico, southern California, and central California impossible. This is the reason behind comparing corrected larval density data from southern California and Mexico with GSI data collected from central California.

GSI data for central California were limited to the summer months of 2012 and 2013. I was unable to evaluate winter- or spring-time spawning activity in central California due to a lack of commercially and recreationally caught fish during 
those time periods. The absence of fish caught during winter and spring is thought to result from seasonal, inshore-offshore migrations along central California. Because the vast majority of fish collected as part of this study were found in a reproductively active state, seasonal migrations would suggest a cessation of spawning (at least the population level) during times when California Halibut are not found en masse nearshore. However, movement patterns of adult California Halibut, especially north of Point Conception, remain undocumented. Therefore, a tagging study is necessary to test this hypothesis of seasonal migrations off of central California and to identify potential drivers of such migrations, if any were found.

Using reproductive data from all three regions (i.e., corrected larval densities from southern California and Mexico and GSI data from central California), I was able to detect patterns in spawning activity of California Halibut. During the spring, increases in reproductive effort appear to be synchronized in southern California and Mexico, but are undocumented or non-existent in central California. Additionally, a latitudinal gradient in summer spawning activity is evident, with peaks earliest in Mexico in May, followed by southern California in June, and finally by central California in July. Though this pattern matches that of other West Coast flatfishes (e.g., Citharichthys spp, Chamberlain 1979), it is opposite to other Paralichthys spp. studied along the east coast of the United States, where spawning takes place earliest in northerly regions (e.g., Summer Flounder, Smith 1973).

In a captive study using natural conditions for southern California, Caddell et al. (1990) suggested that temperature and photoperiod were the most important factors influencing the spawning activity of California Halibut. Spawning was 
observed at sea surface temperatures between 15.0 and $16.5^{\circ} \mathrm{C}$ and day lengths greater than or equal to $10.5 \mathrm{hr}$. However, my data from central California Halibut show that spawning can occur in waters much cooler than $15.0^{\circ} \mathrm{C}$. In central California, strong and persistent upwelling tends to advect pelagic larvae offshore (Morgan 2014). Perhaps relaxation events, which increase larval retention and nearshore settlement (Johannes 1978), are more important drivers of spawning north of Point Conception. Because this is purely conjecture, additional research about the abiotic impacts on California Halibut reproduction and larval survivorship are necessary, both to provide stronger inferences and to enable predictive capabilities that are useful for resource management.

In addition to reproducing at different times and under different conditions, central California Halibut spawned much more frequently than previously described for southern California conspecifics. Wild-caught specimens from my study were estimated to spawn once every $3.2 \mathrm{~d}$ ( 25 times per summer season), whereas captive fish from southern California spawned once every $14.0 \mathrm{~d}$ (13 times per season) (Caddell et al. 1990). Under artificial conditions, southern California Halibut were found to spawn once every $4.7 \mathrm{~d}$ (55 times per season) (Caddell et al. 1990).

Mean batch fecundity from my study and that of Caddell et al. (1990) was 498,830 and 589,000 eggs, respectively. These estimates produce a mean seasonal fecundity of $12,470,750$ eggs per female in central California and $7,657,000$ eggs per female in southern California. However, there are issues associated with both studies that cause these estimates of fecundity to be conservative. 
Estimates of batch fecundity from my study in central California are considered conservative due to the ephemeral nature of oocyte hydration and release. Additionally, financial and logistical limitations prevented the design of a sampling program that would have maximized the number of hydrated oocytes in wild-caught fish (i.e., fishery-independent sampling efforts that adjusted the timing of capture to just before spawning, when eggs were fully hydrated, but not yet released). Although California Halibut have been observed spawning in the late afternoon and throughout the night (Caddell et al. 1990), when low-light conditions reduce the probability of predation (Johannes 1978), commercial and recreational fishers put forth the most effort during early morning and daytime hours. Opportunistic sampling, therefore, led to the collection of females that were in various stages of hydration and spawning, when the number of eggs would have most likely been less than the absolute maximum. Batch fecundity counts for females undergoing hydration were underestimated because fully mature (i.e., final maturation) oocytes, which are likely to hydrate and be released along with cooccurring hydrated oocytes found in the ovary at the time of capture, were not counted because of great difficulty in differentiating them from maturing (i.e., yolk granule) oocytes. For fully hydrated females, batch fecundity counts were underestimated due to a release of some hydrated eggs either prior to or during capture, as evidenced by the presence of new postovulatory follicles.

Although utilizing the help of the fishing community greatly increased my sample sizes for fecundity estimation, it primarily yielded females from one of the two categories detailed above and reduced the probability of sampling fully hydrated, 
pre-spawning females. Therefore, further research aimed at determining the exact timing and biological and/or environmental drivers of California Halibut spawning, combined with an appropriately-timed sampling program, would increase the accuracy of batch fecundity estimates concerning wild fish.

The laboratory study conducted by Caddell et al. (1990) is also considered conservative because of physiological limitations to spawning fish in captivity. The egg collection method that is often used to estimate fecundity in a captive setting is problematic because the person conducting the study is unable to discern which eggs came from which female. Thus, Caddell et al. (1990) made the assumption that each female spawned independent of all others. The authors indicated that this assumption probably inflated the interspawning interval (i.e., ISI $=14 \mathrm{~d}$ ) because it is highly likely that multiple females spawned simultaneously. Another issue associated with fecundity estimates made by Caddell et al. (1990) is that the authors averaged the total number of eggs collected by the total number of females present in that particular tank. This assumes that all females in the tank contributed to the total number of eggs produced during that event. Along with less than ideal spawning conditions that are inherent in artificial environments, this procedure likely produced lesser estimates of individual batch fecundity.

Although much remains to be learned about California Halibut spawning behavior, the co-occurrence of postovulatory follicles (a sign of recent spawning activity) and maturing oocytes, makes it clear that California Halibut exhibit a heterochronal (i.e., multiple) spawning strategy, similar to that described by Holden and Raitt (1974). Additionally, a random mixture of oocytes from all maturity stages 
was observed in mature fish, indicating asynchronous development (Marza 1938; Wallace and Selman 1981). This asynchronous development is evidence of persistent vitellogenesis (i.e., egg production), indicating extreme indeterminate fecundity, where yolked oocytes continue to develop and mature throughout the spawning season (Hunter et al. 1985). The reproductive tactic of indeterminacy found for California Halibut fits within the existing paradigm for species with warm temperate or subtropical distributions (Blaxter and Hunter 1982; Hunter et al. 1992, Armstrong and Witthames 2012) and protracted spawning seasons (Hickling and Rutenberg 1936; Rijnsdorp and Witthames 2005).

Though California Halibut was already recognized as a multiple spawner, this is the first description of its indeterminate reproductive strategy and method of ovarian development. This is also the first attempt to describe fecundity for wildcaught California Halibut and put together the components of spawning activity to assess seasonal reproductive potential for this species.

The proportion of reproductive females, when combined with sex ratio, size structure, and abundance estimates, will allow fishery scientists to estimate spawning stock biomass, a parameter useful in the stock assessment process. If a similar study were to be continued, time series data could also provide insight into the spawner-recruitment relationship for California Halibut, which is currently estimated from data pertaining to another flatfish species (Maunder et al. 2011). Additionally, total mortality estimates, obtained from age frequency data, can be used in conjunction with estimates of fishing mortality to approximate natural mortality for California Halibut. However, a longer time series of total mortality 
estimates, which would encompass variation in California Halibut recruitment strength, would be valuable because catch curve analysis is sensitive to both strong and weak recruitment events.

Overall, this research provides sex-specific and spatially-explicit compositional data, growth rate information, estimates of reproductive potential, and an evaluation of total mortality for California Halibut. Reproductive components of this work will be combined with similarly collected data by CDFW staff in San Francisco Bay to enable the construction of maturity curves for central California Halibut. Finally, the results from this thesis have been made available to the California Department of Fish and Wildlife for incorporation into the next stock assessment and are expected to better inform future management strategies pertaining to the harvest and conservation of California Halibut. 


\section{LITERATURE CITED}

Adams, P.B. 1980. Life history patterns in marine fishes and their consequences for fisheries management. US Fish. Bull. 78. 1-12.

Allen, L.G.1988. Recruitment, distribution, and feeding habits of young-of-the-year California halibut (Paralichthys californicus) in the vicinity of Alamitos BayLong Beach Harbor, California, 1983-1985. Bull. of So. Calif. Acad. of Sci. 87: 19-30.

Allen, M.J. and K.T. Herbinson. 1990. Settlement of juvenile California halibut, Paralichthys californicus, along the coasts of Los Angeles, Orange, and San Diego counties in 1989. CalCOFI Rep. 31: 84-96.

Allen, L.G., R.E. Jensen, and J.R. Sears. 1990. Research Note: Open coast settlement and distribution of young-of the-year California halibut (Paralichthys californicus) along the southern California coast between Point Conception and San Mateo Point, June-October, 1988. In C.W. Haugen (ed.), The California halibut, Paralichthys californicus, resource and fisheries. California Department of Fish and Game. Fish Bull. 174: 145-152.

Almatar, S.M., K.P. Lone, T.S. Abu-Rezq, and A.A. Yousef. 2004. Spawning frequency, fecundity, egg weight and spawning type of silver pomfret, Pampus argentus (Euphrasen) (Stromateidae), in Kuwait waters. J. of Appl. Ichthyol. 20: 176-188.

Armstrong, M.J. and P.R. Witthames. 2012. Developments in understanding of fecundity of fish stocks in relation to egg production methods for estimating spawning stock biomass. Fish. Res. 117-118: 35-47.

Bagenal, T.B. 1978. Aspects of fish fecundity in ecology of freshwater fish production. Blackwell Scientific Publications. 75-102.

Barsky, K.C. 1990. History of the commercial California Halibut fishery. In C.W. Haugen (ed.), The California halibut, Paralichthys californicus, resource and fisheries. California Department of Fish and Game. Fish Bull. 174: 217-227.

Blaxter, J. and J.R. Hunter. 1982. The biology of clupeoid fishes. Adv. Mar. Biol. 20: 1-123.

Caddell, S.M., D.M. Gadomski, and L.R. Abbott. 1990. Induced spawning of the California halibut, Paralichthys californicus, (Pisces: Paralichthyidae) under artificial and natural conditions. In C.W. Haugen (ed.), The California halibut, Paralichthys californicus, resource and fisheries. California Department of Fish and Game. Fish Bull. 174: 175-198. 
California Cooperative Oceanic Fisheries Investigation (CalCOFI). 2014. California Halibut, Paralichthys californicus, ichthyoplankton data, 1980 to 2011. https://oceaninformatics.ucsd.edu/ichthyoplankton/. Accessed October 2014.

California Department of Fish and Game (CDFG). 2011a. Significant milestones in California Halibut fishery management. 3 pp. https://nrm.dfg.ca.gov/FileHandler.ashx?DocumentID=36260

California Department of Fish and Game (CDFG). 2011b. 2011-2012 Prioritized CDFG research needs. Prepared by Debbie Aseltine-Neilson. 2 pp. http://www.cfr-west.org/CFR_West/Grant_FAQs_files/Draft $\% 202010 \% 20$ \%202011-12\%20Prioritized\%20Research\%20Qüestions.pdf. Accessed October 2011.

California Department of Fish and Wildlife (CDFW). 2014. Recreational and commercial landings data for California Halibut, 2004 to 2013. Recreational Fisheries Information Network (RecFIN), http://www.recfin.org/sample-data. Travis Tanaka, personal communication. October 2014.

Caselle, J.E., M.H. Carr, D.P. Malone, J.R. Wilson, and D.E. Wendt. 2010. Can we predict interannual and regional variation in the delivery of pelagic juveniles to nearshore populations of rockfishes (genus Sebastes) using simple proxies of ocean conditions? CalCOFI Rep. 51: 91-105.

Caselle, J. E., S. L. Hamilton, D. M. Schroeder, M. S. Love, J. D. Standish, J. A. Rosales-Casian, and O. Sosa-Nishizaki. 2011. Geographic variation in density, demography, and life history traits of a harvested, sex-changing, temperate reef fish. Can. J. Fish. Aquat. Sci. 68: 288-303.

Chamberlain, D.W. 1979. Histology of the reproductive systems and comparison of selected morphological characters in four Easter Pacific species of Citharichthys (Pisces: Bothidae). PhD Dissertation. University of Southern California. 297 pp.

Clark, G.H. 1930. California halibut. California Department of Fish and Game. Fish Bull. 16: 315-317.

Committee of Age-Reading Experts (CARE). 2006. Manual on generalized age determination: procedures for groundfish. Pacific States Marine Fisheries Commission. $57 \mathrm{pp}$.

Cope, J.M. and A.E. Punt. 2011. Reconciling stock assessment and management scales under conditions of spatially varying catch histories. Fish. Res. 107: 22-38. 
Delahunty, G. and V.L. de Vlaming. 1980. Seasonal relationship of ovary weight, liver weight and fat stores with body weight in the goldfish, Carassius auratus (L.) J. Fish Biol. 16: 5-13.

DeMartini, E.E. and R.K. Fountain. 1981. Ovarian cycling frequency and batch fecundity in the Queenfish, Seriphus politus: attributes representative of serial spawning fishes. US Fish. Bull. 79 (3): 547-560.

de Vlaming, V.L., G. Grossman, and F. Chapman. 1982. On the use of gonadosomatic index. Compar. Biochem. Physiol. 73A: 31-39.

Domeier, M.L. and C.S.Y. Chun. 1995. A tagging study of the California halibut (Paralichthys californicus). CalCOFI Rep. 36: 204-207.

Eschmeyer, W.N., E.S. Herald, and H. Hammann. 1983. A field guide to Pacific coast fishes of North America. Houghton Mifflin Company, Boston, MA. $336 \mathrm{pp}$.

Etzold, D.J. and J.Y. Christmas, eds. 1979. A Mississippi marine finfish management plan. Mississippi - Alabama Sea Grant Consortium. MAGSP-78-046. 36 pp.

Feder, H.M., C.H. Turner, and C. Limbaugh. 1974. Observations on fishes associated with kelp beds in southern California. California Department of Fish and Game. Fish Bull. 160: 105-107.

Ferreira, B.P. and G.R. Russ. 1994. Age validation and estimation of growth rate of the coral trout, Plectropomus maculatus (Pisces: Serranidae) from the Central Great Barrier Reef, Australia. Aust. J. Mar. Freshw. Res. 43: 1301-1312.

Frey, H.W. 1971. California's living marine resources and their utilization. California Department of Fish and Game. Sacramento, California. 148 pp.

Garcia, S.M., K.G. Cochrane, G. van Santen, and F. Christy. 1999. Towards sustainable fisheries: a strategy for FAO and the World Bank. Ocean Coast. Manage. 42: 369-398.

Gibson, R.N. 2005. Flatfishes: biology and exploitation. Fish and Aquatic Resources, Series 9. Blackwell Publishing. Oxford, UK. 391 pp.

Haaker, P.L. 1975. The biology of the California halibut, Paralichthys californicus (Ayres) in Anaheim Bay. In E. D. Lane and C. W. Hill (eds.), The Marine Resources of Anaheim Bay. California Department of Fish and Game. Fish Bull. 165: 137-151. 
Hamilton, S.L., J.R. Wilson, T. Ben-Horin, and J.E. Caselle. 2011. Utilizing spatial demographic and life history variation to optimize sustainable yield of a temperate sex-changing fish. PLoS ONE. 6 (9): e24580.

Hammann, M.G. and A.A. Ramirez-Gonzalez. 1990. California halibut, Paralichthys californicus, in Todos Santos Bay, Baja, Mexico. In C.W. Haugen (ed.) The California halibut, Paralichthys californicus, resource and fisheries. California Department of Fish and Game. Fish Bull. 174. 127-144.

Hedgecock, D. 1994. Temporal and spatial genetic structure of marine animal populations in the California Current. CalCOFI Rep. 35: 73-81.

Hickling, C.F. and E. Rutenberg.1936. The ovary as an indicator of the spawning period in fishes. J. Mar. Biol. Assoc. Plymouth NS. 21. 311-317.

Hile, R. (1936). Age and growth of the cisco Leucichthys artedi (Le Sueur), in the lakes of the north-eastern highlands, Wisconsin. Bull. Bur. Fish. 48: $21 \mathrm{I}-3 \mathrm{I} 7$.

Holden, M.J. and D.F.S. Raitt. 1974. Manual of fisheries science. Methods of resource investigation and their application. FAO Fish. Techn. Pap. 115 (1). $211 \mathrm{pp}$.

Hunter, J.R. and S.R. Goldberg. 1980. Spawning incidence and batch fecundity in northern anchovy, Engraulis mordax. US Fish. Bull. 77: 641-652.

Hunter, J.R. and B.J. Macewicz. 1980. Sexual maturity, batch fecundity, spawning frequency and temporal pattern in the northern anchovy, Engraulis mordax, during the 1979 spawning season. CalCOFI Rep. 21: 139-149.

Hunter, J.R. and B.J. Macewicz. 1985. Rates of atresia of the ovary of captive and wild northern anchovy, Engraulis mordax. US Fish. Bull. 83: 119-136.

Hunter, J.R., N.C.H. Lo, and R.J.H. Leong. 1985. Batch fecundity in multiple spawning fishes. NMFS Tech. Rep. 8547. 67-77.

Hunter, J.R., B.J. Macewicz, N.C.H. Lo, and C.A. Kimbrell. 1992. Fecundity, spawning, and maturity of female Dover Sole, Microstomus pacificus, with and evaluation of assumptions and precision. US Fish. Bull. 90: 101-128.

Johannes, R.E. 1978. Reproductive strategies of coastal marine fishes in the tropics. Environ. Biol. Fish. 3: 65-84.

Junquera, S. and J. Zammaro. 1994. Sexual maturity and spawning of Greenland halibut (Reinhardtius hippoglossoides) from Flemish Pass area. NAFO Sci. Council Studies. 20: 47-52. 
Kimura, D.K. 1980. Likelihood methods for the von Bertalanffy growth curve. US Fish. Bull. 77 (4): 765-776.

Kramer, S.H., J.S. Sunada, and S.P. Wertz. 2001. California halibut. In W.S. Leet, C.M. Dewees, R. Klingbeil and E.J. Larson (eds)., California's Living Marine Resources: A Status Report. California Department of Fish and Game. Sacramento, California. 195-198.

Kramer, S.H. 1991. The shallow-water flatfishes of San Diego County. California CalCOFI Rep. 32: 128-142.

Kramer, S.H. 1990. Distribution and abundance of juvenile California halibut, Paralichthys californicus, in shallow waters of San Diego County. In C.W. Haugen (ed)., The California halibut, Paralichthys californicus, resource and fisheries. California Department of Fish and Game. Fish Bull. 174: 99-126.

Kurita, Y., Y. Fujinami, and M. Amano. 2011. The effect of temperature on the duration of spawning marker - migratory-nucleus and hydrated oocytes and postovulatory follicles - in the multiple-batch spawner Japanese flounder (Paralichthys olivaceus). US Fish. Bulletin. 109: 79-89.

Lavenberg, R.J., G.E. McGowen, A.E. Jahn, J.H. Petersen, and T.C.Sciarrotta. 1986. Abundance of southern California nearshore ichthyoplankton: 19781984. CalCOFI Rep. 27: 53-64.

Le Cren, E.D. 1951. The length-weight relationship and seasonal cycle in gonad weight and condition in the Perch (Perca fluviatilis). J. Anim. Ecol. 20 (2): 201-219.

Leis, J.M. 2007. Behaviour as input for modeling dispersal of fish larvae: behaviour, biogeography, hydrodynamics, ontogeny, physiology and phylogeny meet hydrography. Mar. Ecol. Prog. Ser. 347: 185-193.

Levins, R. 1969. Some demographic and genetic consequences of environmental heterogeneity for biological control. Bull. Entomol. Soc. Am. 15: 237-240.

Love, M.S. and A. Brooks. 1990. Size and age at first maturity of the California halibut, Paralichthys californicus, in the Southern California Bight. In C.W. Haugen (ed)., The California halibut, Paralichthys californicus, resource and fisheries. California Department of Fish and Game. Fish Bull. 174: 167-174.

Luna. L.G. 1968. Manual of histologic staining methods of the armed forces institute of pathology, third edition. McGraw-Hill. New York, NY. 258 pp. 
Macewicz, H.J. and J.R. Hunter. 1993. Spawning frequency and batch fecundity of jack mackerel, Trachurus symmetricus, off California during 1991. CalCOFI Rep. 34: 112-121.

MacNair, L.S., M.L. Domeier, and C.S.Y. Chuen. 2001. Age, growth, and mortality of California halibut, Paralichthys californicus, along southern and central California. Fish Bull. 99: 588-600.

Martin, W.R. 1949. The mechanics of environmental control of body form in fishes. University of Toronto Study of Biology 58. Publ. Ontario Fish. Res. Lab. 70: I-9I.

Marza, V.D. 1938. Histophysiologie de l'ovogenese. Hermann, Paris. 81 pp.

Maunder, M., P. Reilly, T. Tanaka, G. Schmidt and K. Penttila. 2011. California halibut stock assessment. California Department of Fish and Game. https://www.dfg.ca.gov/marine/sfmp/halibut-assessment.asp

Miller, D.J. and R.N. Lea. 1972. Guide to the coastal marine fishes of California. California Department of Fish and Game. Fish Bull. 157: 199.

Minami, T. and M. Tanaka. 1992. Life history cycles in flatfish from the northwestern Pacific, with particular reference to their early life histories. Netherlands $\mathrm{J}$. Sea Res. 29: 35-48.

Morgan, S.G. 2014. Behaviorally mediated larval transport in upwelling systems. Adv. Oceanogr. Hindawi Publishing Corporation. 1-17.

Morse, W.W. 1981. Reproduction of the summer flounder, Paralichthys dentatus (L.). J. Fish Biol. 19: 189-203.

Murua, H., G. Kraus, F. Saborido-Rey, P.R. Witthames, A. Thorsen, and S. Junquera. 2003. Procedures to estimate fecundity of marine fish species in relation to their reproductive strategy. J. Northwest Atl. Fish. Sci. 33: 33-54.

Nall, L.E. 1979. Age and growth of the southern flounder (Paralichthys lethostigma) in the northern Gulf of Mexico with notes on Paralichthys albigutta. Masters Thesis, Florida State University. 58 pp.

Nissling, A. and G. Dahlman. 2010. Fecundity of flounder, Pleuronectes flesus, in the Baltic Sea - reproductive strategies in two sympatric populations. J. Sea Res. 64 (2010): 190-198.

Orensanz, J.M., A.M. Parma, G. Jerez, N. Barahona, M. Montecinos, and I. Elías. 2005. What are the key elements for the sustainability of 'S-fisheries'? Insights from South America. Bull. Mar. Sci. 76 (2): 527-556. 
Packer, D.B., S.J. Griesbach, P.L. Berrien, C.A. Zetlin, D.L. Johnson, and W.W. Morse. 1999. Summer Flounder, Paralichthys dentatus, life history and habitat characteristics. NOAA Techn. Mem. NMFS-NE151, Essential Fish Habitat Source Document. 98 pp.

Parker, K. 1980. A direct method for estimating northern anchovy, Engraulis mordax, spawning biomass. US Fish. Bull. 78. 541-544.

Pascoe, S., R. Bustamante, C. Wilcox, and M. Gibbs. 2009. Spatial fisheries management: a framework for multi-objective qualitative assessment. Ocean Coast. Manage. 52 (2): 130-138.

Patterson, K.R. 1999. Evaluating uncertainty in harvest control law catches using Bayesian Markov chain Monte Carlo virtual population analysis with adaptive rejection sampling and including structural uncertainty. Can. J. Fish. Aquat. Sci. 56: 208-221.

Prince, J. 2010. Rescaling fisheries assessment and management: a generic approach, access rights, change agents, and toolboxes. Bull. Mar. Sci. 86: 197-219.

Quinn, T.J. and R.B. Deriso. 1999. Quantitative Fish Dynamics. Oxford University Press. New York, NY. 542 pp.

Rice, J., S.X. Cadrin, and W.G. Clark. 2005. Assessment and management of flatfish stocks. In Gibson, R.N. (Ed.). Flatfishes, Biology and Exploitation. Blackwell Science Ltd. Oxford, UK. 319-346.

Rijnsdorp, A.D., and P.R. Witthames. 2005. Ecology of reproduction. In Gibson, R. N. (ed.), Flatfishes: Biology and Exploitation. Fish and Aquatic Resources. Series 9. Blackwell Science, Oxford. 68-93.

Robertson, D.R., J.L. Ackerman, J.H. Choat, J.M. Posada, and J. Pitt. 2005. Ocean surgeonfish Acanthurus bahianus. I. The geography and demography. Mar. Ecol. Prog. Ser. 295: 229-244.

Serchuk, F.M., E. Kirkegaard, and N. Daan. 1996. Status and trends of the major roundfish, flatfish, and pelagic fish stocks in the North Sea: thirty-year overview. ICES J. Mar. Sci. 53: 1130-1145.

Smith, W.G. 1973. The distribution of summer flounder, Paralichthys dentatus, eggs and larvae on the continental shelf between Cape Cod and Cape Lookout, 1965-66. US Fish. Bull. 71: 527-548.

Somero, G.N. 2005. Linking biogeography to physiology: Evolutionary and acclamatory adjustments of thermal limits. Front. Zool. 2 (1). 
Spencer, P.D. 2008. Density-independent and density-dependent factors affecting temporal changes in spatial distributions of eastern Bering Sea flatfish. Fish. Oceanogr. 17 (5): 396-410.

Sunada, J.S., P.V. Velez, and C.A. Pattison. 1990. Age, size, and sex composition of California Halibut in southern California commercial fishery landings, 19831988. In C.W. Haugen (ed)., The California halibut, Paralichthys californicus, resource and fisheries. California Department of Fish and Game. Fish Bull. 174: 303-320.

Valle, C.F., J.W. O'Brien, and K.B. Wiese. 1998. Differential habitat use by California halibut, Paralichthys californicus, barred sand bass, Paralabrax nebulifer, and other juvenile fishes in Alamitos Bay, California. California Department of Fish and Game. Fish Bull. 97: 646-660.

von Bertalanffy, L. 1938. A quantitative theory of organic growth. Hum. Biol. 10: 181-213.

Wallace, R. and K. Selman. 1979. Physiological aspects of oogenesis in two species of stickleback, Gasterosteus aculeatus L. and Apeltes quadracus (Mitchell). J. Fish Biol. 14: 551-564.

Wallace, R. and K. Selman. 1981. Cellular and dynamic aspects of oocyte growth in teleosts. Am. Zool. 21: 325-343.

Wilderbuer, T.K. and D.G. Nichol. 2013. Assessment of the other flatfish complex in the Bering Sea and Aleutian Islands. NPFMC Bering Sea and Aleutian Islands SAFE. BSAI Other Flatfish. 839-853. http://www.afsc.noaa.gov/REFM/Docs/2013/BSAloflat.pdf

Witthames, P.R., M. Greer Walker, M.T. Dinis, and C.L. Whiting. 1995. The geographic variation in the potential annual fecundity of Dover sole, Solea solea (L.) from European shelf waters during 1991. Netherlands J. Sea Res. 34: $45-58$.

Wootton, R.J., G.W. Evans, and L.A. Mills. 1978. Annual cycle in female threespined sticklebacks (Gasterosteus aculeatus L.) from an upland and lowland population. J. Fish Biol. 12: 331-343.

Yoneda, M., Y. Kurita, D. Kitagawa, and M. Ito. 2007. Spatial variation in the relationship between growth and maturation rate in male Japanese flounder Paralichthys olivaceus off the Pacific coast of northern Japan. J. Sea Res. 57: 171-179. 
APPENDIX I

Data associated with California Halibut collected off of central California (2012 and 2013). Site: SFB = San Francisco Bay, HMB = Half Moon Bay, SC = Santa Cruz, ML = Moss Landing, MT = Monterey, MB = Morro Bay, PSL = Port San Luis; Fishery: $C=$ commercial, $R=$ recreational; Gear Type: $H \& L=$ hook-and-line, $S P=$ spear, $S E=$ seine; Sex: $F=$ female, $M=$ male; Macro[scopic] Mat[urity]: 0 = immature, $1=$ mature; Micro[scopic] Mat[urity]: $1=$ immature, $2=$ maturing, 3 = mature; 4 = spawning, 5 = spent, 6 = resting. Missing values are a result of fish that were donated as filleted carcasses, not retained, or not fully processed due to some sort of damage (e.g., cut organs, broken otolith).

\begin{tabular}{|c|c|c|c|c|c|c|c|c|c|c|c|c|}
\hline No. & Date & Site & Fishery & $\begin{array}{l}\text { Gear } \\
\text { Type }\end{array}$ & Sex & $\begin{array}{l}\text { Length } \\
(\mathrm{mm})^{1}\end{array}$ & $\begin{array}{l}\text { Age } \\
(\mathrm{yr})\end{array}$ & $\begin{array}{c}\text { Body } \\
\text { Mass (g) }\end{array}$ & $\begin{array}{c}\text { Gonad } \\
\text { Mass (g) }\end{array}$ & $\begin{array}{c}\text { Liver } \\
\text { Mass (g) }\end{array}$ & $\begin{array}{c}\text { Macro } \\
\text { Mat }\end{array}$ & $\begin{array}{c}\text { Micro } \\
\text { Mat }\end{array}$ \\
\hline 1 & $06 / 03 / 12$ & SC & $\mathrm{R}$ & H\&L & $\mathrm{F}$ & 725 & & 3997 & 16.2 & 32.1 & 0 & \\
\hline 2 & $06 / 14 / 12$ & SC & $\mathrm{R}$ & H\&L & $\mathrm{F}$ & 770 & 8 & 4593 & & & & \\
\hline 3 & $06 / 14 / 12$ & SC & $\mathrm{R}$ & H\&L & $\mathrm{F}$ & 823 & 6 & 5160 & & & & \\
\hline 4 & $06 / 16 / 12$ & SC & $\mathrm{R}$ & H\&L & $F$ & 705 & 8 & & 138.1 & 51.6 & 1 & 3 \\
\hline 5 & $06 / 17 / 12$ & SC & $\mathrm{R}$ & H\&L & $F$ & 756 & 6 & 4338 & 112.7 & 48.6 & 1 & 3 \\
\hline 6 & 06/17/12 & SC & $\mathrm{R}$ & H\&L & $M$ & 809 & 8 & & 284.0 & 57.6 & & \\
\hline 7 & $06 / 17 / 12$ & SC & $\mathrm{R}$ & H\&L & $M$ & 847 & 16 & 5954 & 387.4 & 39.2 & & \\
\hline 8 & $06 / 18 / 12$ & PSL & $\mathrm{R}$ & $\mathrm{SP}$ & $\mathrm{F}$ & 741 & 8 & & 38.7 & 50.3 & 0 & 2 \\
\hline 9 & 06/20/12 & SC & $\mathrm{R}$ & H\&L & $F$ & 803 & 7 & & 241.1 & 73.7 & 1 & 4 \\
\hline 10 & $06 / 22 / 12$ & MT & & H\&L & $\mathrm{F}$ & 668 & 6 & & 77.0 & 65.7 & 0 & 3 \\
\hline 11 & $06 / 23 / 12$ & MB & $\mathrm{R}$ & H\&L & $M$ & 819 & 16 & 6095 & & & & \\
\hline 12 & $06 / 24 / 12$ & PSL & $\mathrm{R}$ & $\mathrm{SP}$ & $\mathrm{F}$ & 641 & 5 & 2495 & 25.7 & 26.1 & 0 & 2 \\
\hline 13 & 06/29/12 & PSL & $\mathrm{R}$ & $\mathrm{SP}$ & $F$ & 740 & 8 & & 77.1 & 52.3 & 0 & 3 \\
\hline 14 & 06/30/12 & SC & $\mathrm{R}$ & H\&L & $M$ & 548 & 3 & & 65.1 & 15.2 & 1 & \\
\hline 15 & $07 / 01 / 12$ & SC & C & H\&L & $M$ & 645 & 9 & 2778 & 86.6 & 26.7 & 1 & \\
\hline 16 & $07 / 01 / 12$ & SC & C & H\&L & $M$ & 602 & 6 & 2438 & 81.5 & 19.3 & 1 & \\
\hline 17 & $07 / 01 / 12$ & SC & C & H\&L & $\mathrm{F}$ & 843 & & 6832 & 307.7 & 112.0 & 1 & 3 \\
\hline 18 & $07 / 01 / 12$ & SC & $\mathrm{R}$ & H\&L & $\mathrm{F}$ & 836 & 6 & 6209 & 186.1 & 86.9 & 1 & 4 \\
\hline 19 & $07 / 01 / 12$ & SC & $\mathrm{R}$ & H\&L & $M$ & 572 & 6 & & 117.4 & 20.3 & & \\
\hline 20 & $07 / 01 / 12$ & SC & $\mathrm{R}$ & H\&L & $M$ & 559 & & & 98.8 & 12.8 & 1 & \\
\hline
\end{tabular}




\begin{tabular}{|c|c|c|c|c|c|c|c|c|c|c|c|c|}
\hline No. & Date & Site & Fishery & $\begin{array}{l}\text { Gear } \\
\text { Type }\end{array}$ & Sex & $\begin{array}{l}\text { Length } \\
(\mathrm{mm})^{1}\end{array}$ & $\begin{array}{l}\text { Age } \\
(\mathrm{yr})\end{array}$ & $\begin{array}{c}\text { Body } \\
\text { Mass (g) }\end{array}$ & $\begin{array}{c}\text { Gonad } \\
\text { Mass }(\mathrm{g})\end{array}$ & $\begin{array}{c}\text { Liver } \\
\text { Mass (g) }\end{array}$ & $\begin{array}{c}\text { Macro } \\
\text { Mat }\end{array}$ & $\begin{array}{c}\text { Micro } \\
\text { Mat }\end{array}$ \\
\hline 21 & 07/03/12 & SC & $\mathrm{R}$ & $H \& L$ & $\mathrm{~F}$ & 812 & 8 & & 235.9 & 72.6 & 1 & 3 \\
\hline 22 & $07 / 04 / 12$ & SC & $\mathrm{R}$ & $H \& L$ & $\mathrm{~F}$ & 893 & 9 & & 353.4 & 82.7 & 1 & 4 \\
\hline 23 & $07 / 04 / 12$ & SC & $\mathrm{R}$ & $H \& L$ & $\mathrm{~F}$ & 783 & 7 & & & 85.6 & 1 & \\
\hline 24 & $07 / 06 / 12$ & SC & $\mathrm{R}$ & $H \& L$ & M & 707 & 6 & & 106.7 & 27.4 & 1 & \\
\hline 25 & $07 / 06 / 12$ & SC & $\mathrm{R}$ & $H \& L$ & M & 792 & 16 & & 160.2 & 36.5 & 1 & \\
\hline 26 & 07/09/12 & SC & $\mathrm{R}$ & $H \& L$ & M & 692 & 7 & & 47.1 & 30.9 & 1 & \\
\hline 27 & $07 / 11 / 12$ & SC & $\mathrm{R}$ & $H \& L$ & $\mathrm{~F}$ & 904 & 7 & & 460.9 & 129.5 & 1 & 4 \\
\hline 28 & $07 / 11 / 12$ & SC & C & $H \& L$ & $\mathrm{~F}$ & 884 & 7 & & 441.3 & 150.8 & 1 & 4 \\
\hline 29 & $07 / 12 / 12$ & SC & $\mathrm{R}$ & $H \& L$ & $\mathrm{~F}$ & 705 & 6 & & & & 1 & \\
\hline 30 & $07 / 12 / 12$ & SC & $\mathrm{R}$ & $H \& L$ & $\mathrm{~F}$ & 820 & & & & 97.3 & 1 & \\
\hline 31 & $07 / 13 / 12$ & MT & $\mathrm{R}$ & $H \& L$ & $\mathrm{~F}$ & 793 & 8 & & 283.5 & 86.2 & 1 & 4 \\
\hline 32 & $07 / 14 / 12$ & HMB & $\mathrm{R}$ & $H \& L$ & $\mathrm{~F}$ & 827 & 9 & & 154.8 & 108.1 & 1 & 3 \\
\hline 33 & $07 / 14 / 12$ & $\mathrm{SC}$ & $\mathrm{R}$ & $H \& L$ & $\mathrm{~F}$ & 649 & 3 & & 31.5 & 42.3 & 0 & 1 or 6 \\
\hline 34 & $07 / 14 / 12$ & SC & $\mathrm{R}$ & $H \& L$ & M & 624 & 8 & & 83.9 & 24.4 & 1 & \\
\hline 35 & 07/15/12 & PSL & $\mathrm{R}$ & $H \& L$ & $\mathrm{~F}$ & 835 & 9 & 6719 & 79.0 & 74.2 & 0 & 2 \\
\hline 36 & 07/15/12 & PSL & $\mathrm{R}$ & $H \& L$ & $\mathrm{~F}$ & 895 & 7 & 8193 & 340.2 & 123.6 & 1 & 4 \\
\hline 37 & $07 / 15 / 12$ & $\mathrm{SC}$ & $\mathrm{R}$ & $H \& L$ & M & 793 & 8 & & 182.8 & 38.8 & 1 & \\
\hline 38 & $07 / 15 / 12$ & PSL & C & $H \& L$ & $\mathrm{~F}$ & 840 & 8 & 7031 & & 100.3 & 1 & \\
\hline 39 & 07/15/12 & SC & $\mathrm{R}$ & $H \& L$ & M & 605 & 6 & & 73.2 & 13.3 & 1 & \\
\hline 40 & $07 / 20 / 12$ & SC & $\mathrm{R}$ & $\mathrm{H} \& \mathrm{~L}$ & $\mathrm{~F}$ & 865 & 9 & & 371.1 & & 1 & 4 \\
\hline 41 & $07 / 21 / 12$ & SC & $\mathrm{R}$ & H\&L & $\mathrm{F}$ & 936 & 9 & & 362.8 & 138.4 & 1 & 3 \\
\hline 42 & $07 / 21 / 12$ & SC & $\mathrm{R}$ & $\mathrm{H} \& \mathrm{~L}$ & M & 724 & 7 & & 79.9 & 18.7 & 1 & \\
\hline 43 & $07 / 21 / 12$ & SC & $\mathrm{R}$ & H\&L & M & 735 & 7 & & 45.6 & 17.4 & 1 & \\
\hline 44 & $07 / 22 / 12$ & SC & $\mathrm{R}$ & $\mathrm{H} \& \mathrm{~L}$ & M & 568 & 8 & & 40.5 & 13.1 & 1 & \\
\hline 45 & $07 / 22 / 12$ & SC & $\mathrm{R}$ & $H \& L$ & $\mathrm{~F}$ & 651 & 3 & & 86.6 & 27.4 & 1 & 3 \\
\hline 46 & $07 / 22 / 12$ & SC & $\mathrm{R}$ & $H \& L$ & M & 836 & 10 & & 180.0 & 529.7 & 1 & \\
\hline
\end{tabular}




\begin{tabular}{|c|c|c|c|c|c|c|c|c|c|c|c|c|}
\hline No. & Date & Site & Fishery & $\begin{array}{l}\text { Gear } \\
\text { Type }\end{array}$ & Sex & $\begin{array}{l}\text { Length } \\
(\mathrm{mm})^{1}\end{array}$ & $\begin{array}{l}\text { Age } \\
(\mathrm{yr})\end{array}$ & $\begin{array}{c}\text { Body } \\
\text { Mass (g) }\end{array}$ & $\begin{array}{c}\text { Gonad } \\
\text { Mass (g) }\end{array}$ & $\begin{array}{c}\text { Liver } \\
\text { Mass (g) }\end{array}$ & $\begin{array}{c}\text { Macro } \\
\text { Mat }\end{array}$ & $\begin{array}{l}\text { Micro } \\
\text { Mat }\end{array}$ \\
\hline 47 & $07 / 22 / 12$ & SC & $\mathrm{R}$ & $\mathrm{H} \& \mathrm{~L}$ & $\mathrm{~F}$ & 862 & 8 & & 305.1 & 102.2 & 1 & 4 \\
\hline 48 & $07 / 22 / 12$ & SC & $\mathrm{R}$ & $H \& L$ & $\mathrm{~F}$ & 887 & 7 & & & 123.4 & 1 & \\
\hline 49 & $07 / 22 / 12$ & SC & $\mathrm{R}$ & $H \& L$ & M & 556 & 6 & & 50.4 & 11.9 & & \\
\hline 50 & $07 / 22 / 12$ & SC & $\mathrm{R}$ & $H \& L$ & $\mathrm{~F}$ & 643 & 8 & & & 26.0 & 1 & \\
\hline 51 & $07 / 22 / 12$ & SC & $\mathrm{R}$ & $H \& L$ & $\mathrm{~F}$ & 725 & 4 & & & 51.3 & 1 & \\
\hline 52 & $07 / 23 / 12$ & SC & $\mathrm{R}$ & $H \& L$ & $\mathrm{~F}$ & 820 & 7 & & & 62.5 & 1 & \\
\hline 53 & $07 / 23 / 12$ & SC & $\mathrm{R}$ & $H \& L$ & M & 791 & 9 & & 162.0 & 31.9 & 1 & \\
\hline 54 & $07 / 23 / 12$ & SC & $\mathrm{R}$ & $H \& L$ & M & 661 & 8 & & 85.1 & 21.1 & 1 & \\
\hline 55 & $07 / 23 / 12$ & SC & $\mathrm{R}$ & $H \& L$ & $\mathrm{~F}$ & 716 & 6 & & 168.9 & 57.7 & 1 & 3 \\
\hline 56 & $07 / 23 / 12$ & SC & $\mathrm{R}$ & $H \& L$ & $\mathrm{~F}$ & 892 & 8 & & 205.9 & 105.2 & 1 & \\
\hline 57 & $07 / 23 / 12$ & SC & $\mathrm{R}$ & $H \& L$ & M & 820 & 13 & & 203.6 & 41.5 & 1 & \\
\hline 58 & $07 / 24 / 12$ & SC & $\mathrm{R}$ & $H \& L$ & $\mathrm{~F}$ & 790 & 7 & & & & 1 & \\
\hline 59 & $07 / 24 / 12$ & SC & $\mathrm{R}$ & $H \& L$ & $\mathrm{~F}$ & 653 & 7 & & & & 1 & \\
\hline 60 & $07 / 25 / 12$ & SC & $\mathrm{R}$ & $H \& L$ & M & 719 & & & 149.1 & 24.2 & 1 & \\
\hline 61 & $07 / 26 / 12$ & SC & $\mathrm{R}$ & $H \& L$ & M & 651 & 7 & & 86.6 & 22.9 & 1 & \\
\hline 62 & $07 / 26 / 12$ & SC & $\mathrm{R}$ & $H \& L$ & M & 694 & 8 & & 61.7 & 27.1 & 1 & \\
\hline 63 & $07 / 26 / 12$ & SC & $\mathrm{R}$ & $H \& L$ & M & 717 & 7 & & 76.8 & 27.2 & 1 & \\
\hline 64 & $07 / 26 / 12$ & SC & $\mathrm{R}$ & $H \& L$ & $\mathrm{~F}$ & 760 & 8 & & 203.8 & 77.1 & 1 & 3 \\
\hline 65 & $07 / 27 / 12$ & SC & $\mathrm{R}$ & $H \& L$ & M & 740 & 14 & & 157.6 & 43.4 & 1 & \\
\hline 66 & $07 / 27 / 12$ & SC & $\mathrm{R}$ & $H \& L$ & $\mathrm{~F}$ & 935 & 7 & & & 129.7 & 1 & \\
\hline 67 & $07 / 28 / 12$ & SC & $\mathrm{R}$ & $H \& L$ & $\mathrm{~F}$ & 1021 & 15 & & 659.5 & 174.5 & 1 & 4 \\
\hline 68 & $07 / 28 / 12$ & SC & $\mathrm{R}$ & $H \& L$ & M & 608 & 8 & 2466 & 69.7 & 17.7 & 1 & \\
\hline 69 & $07 / 28 / 12$ & SC & $\mathrm{R}$ & $H \& L$ & M & 816 & 7 & 5500 & 127.7 & 34.5 & 1 & \\
\hline 70 & $07 / 28 / 12$ & SC & $\mathrm{R}$ & $H \& L$ & $\mathrm{~F}$ & 851 & 8 & & 260.8 & 124.4 & 1 & 4 \\
\hline 71 & $07 / 28 / 12$ & SC & $\mathrm{R}$ & $\mathrm{H} \& \mathrm{~L}$ & M & 806 & & & 100.4 & 38.7 & 1 & \\
\hline 72 & $07 / 28 / 12$ & SC & $\mathrm{R}$ & $H \& L$ & M & 592 & 7 & 2353 & 62.1 & 16.2 & 1 & \\
\hline
\end{tabular}




\begin{tabular}{|c|c|c|c|c|c|c|c|c|c|c|c|c|}
\hline No. & Date & Site & Fishery & $\begin{array}{l}\text { Gear } \\
\text { Type }\end{array}$ & Sex & $\begin{array}{l}\text { Length } \\
(\mathrm{mm})^{1}\end{array}$ & $\begin{array}{l}\text { Age } \\
(\mathrm{yr})\end{array}$ & $\begin{array}{l}\text { Body } \\
\text { Mass (g) }\end{array}$ & $\begin{array}{c}\text { Gonad } \\
\text { Mass (g) }\end{array}$ & $\begin{array}{c}\text { Liver } \\
\text { Mass (g) }\end{array}$ & $\begin{array}{c}\text { Macro } \\
\text { Mat }\end{array}$ & $\begin{array}{c}\text { Micro } \\
\text { Mat }\end{array}$ \\
\hline 73 & $07 / 28 / 12$ & SC & $\mathrm{R}$ & $\mathrm{H} \& \mathrm{~L}$ & $\mathrm{~F}$ & 1169 & 16 & 16953 & 656.4 & 245.6 & 1 & \\
\hline 74 & $07 / 29 / 12$ & SC & $\mathrm{R}$ & $H \& L$ & $\mathrm{~F}$ & 1003 & 14 & & 434.8 & 119.6 & 1 & 3 \\
\hline 75 & $07 / 29 / 12$ & SC & $\mathrm{R}$ & $H \& L$ & M & 709 & 7 & & 57.5 & 31.0 & 1 & \\
\hline 76 & $07 / 29 / 12$ & SC & $\mathrm{R}$ & $H \& L$ & $\mathrm{~F}$ & 670 & 7 & & 130.6 & 46.3 & 1 & 4 \\
\hline 77 & $07 / 29 / 12$ & SC & $\mathrm{R}$ & $H \& L$ & $\mathrm{~F}$ & 753 & 9 & & 255.8 & 53.8 & 1 & 4 \\
\hline 78 & $07 / 29 / 12$ & SC & $\mathrm{R}$ & $H \& L$ & M & 617 & 6 & & 38.4 & 22.2 & 1 & \\
\hline 79 & $07 / 29 / 12$ & SC & $\mathrm{R}$ & $H \& L$ & $\mathrm{~F}$ & 691 & 7 & & 52.8 & 43.7 & 1 & \\
\hline 80 & 07/30/12 & SC & $\mathrm{R}$ & $H \& L$ & $\mathrm{~F}$ & 630 & & 2693 & & & & \\
\hline 81 & 07/30/12 & SC & $\mathrm{R}$ & $H \& L$ & $\mathrm{~F}$ & 714 & & 3941 & & & & \\
\hline 82 & $07 / 30 / 12$ & SC & $\mathrm{R}$ & $H \& L$ & $\mathrm{~F}$ & 778 & & 5755 & & & & \\
\hline 83 & 07/30/12 & SC & $\mathrm{R}$ & $H \& L$ & M & 546 & & & & 13.3 & & \\
\hline 84 & 07/30/12 & SC & $\mathrm{R}$ & $H \& L$ & $\mathrm{~F}$ & 830 & 7 & & & 60.1 & 1 & \\
\hline 85 & 07/30/12 & SC & $\mathrm{R}$ & $H \& L$ & M & 729 & 7 & & 101.8 & 29.6 & 1 & \\
\hline 86 & 07/30/12 & SC & $\mathrm{R}$ & $H \& L$ & M & 662 & 7 & & 58.7 & 20.2 & 1 & \\
\hline 87 & 07/30/12 & SC & $\mathrm{R}$ & $H \& L$ & M & 650 & 7 & & 93.3 & 21.4 & 1 & \\
\hline 88 & 07/30/12 & SC & $\mathrm{R}$ & $H \& L$ & $\mathrm{~F}$ & 694 & 8 & & 110.3 & 33.7 & 1 & 3 \\
\hline 89 & 07/30/12 & SC & $\mathrm{R}$ & $H \& L$ & M & 653 & 7 & & 63.2 & & 1 & \\
\hline 90 & $07 / 31 / 12$ & SC & $\mathrm{R}$ & $H \& L$ & $\mathrm{~F}$ & 796 & 8 & & & 70.0 & 1 & \\
\hline 91 & $07 / 31 / 12$ & SC & $\mathrm{R}$ & $H \& L$ & M & 715 & 7 & & 51.9 & 19.0 & 1 & \\
\hline 92 & $07 / 31 / 12$ & SC & $R$ & $H \& L$ & M & 629 & 6 & & 79.0 & 24.2 & 1 & \\
\hline 93 & $07 / 31 / 12$ & SC & $\mathrm{R}$ & $H \& L$ & M & 758 & 8 & & 66.2 & 40.9 & 1 & \\
\hline 94 & $07 / 31 / 12$ & SC & $\mathrm{R}$ & $H \& L$ & M & 587 & 7 & & 51.3 & 14.9 & & \\
\hline 95 & $07 / 31 / 12$ & SC & $\mathrm{R}$ & $H \& L$ & M & 559 & 7 & & 70.4 & 7.7 & 1 & \\
\hline 96 & $07 / 31 / 12$ & SC & $\mathrm{R}$ & $H \& L$ & M & 679 & 7 & & & 25.8 & 1 & \\
\hline 97 & $07 / 31 / 12$ & SC & $\mathrm{R}$ & $H \& L$ & M & 631 & 6 & 2693 & 43.2 & 19.0 & 1 & \\
\hline 98 & $07 / 31 / 12$ & SC & $\mathrm{R}$ & $H \& L$ & M & 718 & 7 & 3941 & 87.4 & 37.5 & 1 & \\
\hline
\end{tabular}




\begin{tabular}{|c|c|c|c|c|c|c|c|c|c|c|c|c|}
\hline No. & Date & Site & Fishery & $\begin{array}{l}\text { Gear } \\
\text { Type }\end{array}$ & Sex & $\begin{array}{l}\text { Length } \\
(\mathrm{mm})^{1}\end{array}$ & $\begin{array}{l}\text { Age } \\
\text { (yr) }\end{array}$ & $\begin{array}{c}\text { Body } \\
\text { Mass (g) }\end{array}$ & $\begin{array}{c}\text { Gonad } \\
\text { Mass (g) }\end{array}$ & $\begin{array}{c}\text { Liver } \\
\text { Mass (g) }\end{array}$ & $\begin{array}{c}\text { Macro } \\
\text { Mat }\end{array}$ & $\begin{array}{c}\text { Micro } \\
\text { Mat }\end{array}$ \\
\hline 99 & $07 / 31 / 12$ & SC & $\mathrm{R}$ & $H \& L$ & M & 643 & 6 & & 36.2 & 17.0 & 1 & \\
\hline 100 & $07 / 31 / 12$ & SC & $\mathrm{R}$ & $H \& L$ & M & 643 & 5 & & & & & \\
\hline 101 & $07 / 31 / 12$ & SC & $\mathrm{R}$ & $H \& L$ & M & 662 & 8 & & 77.5 & 21.8 & 1 & \\
\hline 102 & $07 / 31 / 12$ & SC & $\mathrm{R}$ & $H \& L$ & M & 703 & & & 76.2 & 26.3 & 1 & \\
\hline 103 & $07 / 31 / 12$ & SC & $\mathrm{R}$ & $H \& L$ & $\mathrm{~F}$ & 785 & 6 & & 196.6 & 67.6 & 1 & 4 \\
\hline 104 & $07 / 31 / 12$ & SC & $\mathrm{R}$ & $H \& L$ & $\mathrm{~F}$ & 767 & 7 & & & 57.0 & 1 & \\
\hline 105 & $07 / 31 / 12$ & SC & $\mathrm{R}$ & $H \& L$ & $\mathrm{~F}$ & 1028 & 9 & & 503.5 & 171.2 & 1 & 3 \\
\hline 106 & $08 / 01 / 12$ & PSL & $\mathrm{R}$ & & $\mathrm{F}$ & 717 & 7 & 4451 & 73.6 & 67.8 & 0 & 5 \\
\hline 107 & 08/01/12 & $\mathrm{SC}$ & $\mathrm{R}$ & $H \& L$ & M & 841 & & & 140.7 & 45.0 & 1 & \\
\hline 108 & $08 / 01 / 12$ & SC & $\mathrm{R}$ & $H \& L$ & $\mathrm{~F}$ & 742 & 8 & & & 72.6 & 1 & \\
\hline 109 & $08 / 01 / 12$ & SC & $\mathrm{R}$ & $H \& L$ & $\mathrm{~F}$ & 660 & & & & 42.0 & 1 & \\
\hline 110 & $08 / 01 / 12$ & SC & $\mathrm{R}$ & $H \& L$ & M & 592 & 8 & & 52.8 & 13.9 & 1 & \\
\hline 111 & $08 / 03 / 12$ & SC & $\mathrm{R}$ & $H \& L$ & M & 711 & 8 & & 58.5 & 40.8 & 1 & \\
\hline 112 & $08 / 03 / 12$ & SC & $\mathrm{R}$ & $H \& L$ & $\mathrm{~F}$ & 701 & 7 & & 168.2 & 64.0 & 1 & 4 \\
\hline 113 & $08 / 05 / 12$ & SC & & $H \& L$ & $\mathrm{~F}$ & 536 & 3 & 1814 & & 18.0 & 0 & 1 or 6 \\
\hline 114 & $08 / 05 / 12$ & SC & $\mathrm{R}$ & $H \& L$ & M & 783 & 9 & & 130.9 & 38.5 & 1 & \\
\hline 115 & $08 / 05 / 12$ & SC & $\mathrm{R}$ & $H \& L$ & M & 751 & 8 & 4848 & 93.5 & 29.7 & 1 & \\
\hline 116 & $08 / 05 / 12$ & SC & $\mathrm{R}$ & $H \& L$ & M & 808 & 9 & 5330 & 147.0 & 42.3 & 1 & \\
\hline 117 & $08 / 05 / 12$ & SC & $\mathrm{R}$ & $H \& L$ & M & 621 & 7 & & & 12.7 & 1 & \\
\hline 118 & $08 / 05 / 12$ & SC & $\mathrm{R}$ & $H \& L$ & $\mathrm{~F}$ & 712 & 7 & & & & 1 & \\
\hline 119 & $08 / 11 / 12$ & PSL & $\mathrm{R}$ & $H \& L$ & M & 662 & & 3062 & & & 1 & \\
\hline 120 & $08 / 11 / 12$ & PSL & $\mathrm{R}$ & $H \& L$ & $\mathrm{~F}$ & 754 & & 4905 & & & & \\
\hline 121 & $08 / 11 / 12$ & PSL & $\mathrm{R}$ & $H \& L$ & $\mathrm{~F}$ & 827 & & 8051 & & & & \\
\hline 122 & $08 / 11 / 12$ & PSL & & $H \& L$ & $\mathrm{~F}$ & 939 & & 9356 & & & & \\
\hline 123 & $08 / 11 / 12$ & PSL & $\mathrm{R}$ & $H \& L$ & $\mathrm{~F}$ & & & 7711 & & & & \\
\hline 124 & $08 / 11 / 12$ & PSL & $\mathrm{R}$ & $H \& L$ & $\mathrm{~F}$ & 611 & 7 & & 28.4 & 31.4 & 0 & 1 or 6 \\
\hline
\end{tabular}




\begin{tabular}{|c|c|c|c|c|c|c|c|c|c|c|c|c|}
\hline No. & Date & Site & Fishery & $\begin{array}{l}\text { Gear } \\
\text { Type }\end{array}$ & Sex & $\begin{array}{l}\text { Length } \\
(\mathrm{mm})^{1}\end{array}$ & $\begin{array}{l}\text { Age } \\
(\mathrm{yr})\end{array}$ & $\begin{array}{c}\text { Body } \\
\text { Mass (g) }\end{array}$ & $\begin{array}{c}\text { Gonad } \\
\text { Mass (g) }\end{array}$ & $\begin{array}{c}\text { Liver } \\
\text { Mass (g) }\end{array}$ & $\begin{array}{c}\text { Macro } \\
\text { Mat }\end{array}$ & $\begin{array}{c}\text { Micro } \\
\text { Mat }\end{array}$ \\
\hline 125 & $08 / 19 / 12$ & SC & C & $\mathrm{H} \& \mathrm{~L}$ & M & 800 & 6 & & 184.5 & 37.0 & 1 & \\
\hline 126 & $08 / 24 / 12$ & $\mathrm{ML}$ & C & $H \& L$ & M & 621 & 8 & & 85.2 & 18.2 & 1 & \\
\hline 127 & $08 / 24 / 12$ & $M L$ & C & $H \& L$ & M & 666 & 7 & & 121.6 & 21.6 & 1 & \\
\hline 128 & $08 / 24 / 12$ & $M L$ & C & $H \& L$ & $\mathrm{~F}$ & 842 & 7 & & 283.2 & 122.8 & 1 & 3 \\
\hline 129 & $08 / 24 / 12$ & ML & C & $H \& L$ & $\mathrm{~F}$ & 840 & 8 & & 176.3 & 116.2 & 1 & \\
\hline 130 & $08 / 24 / 12$ & SC & $\mathrm{R}$ & $H \& L$ & M & 815 & 14 & & 106.1 & 61.2 & 1 & \\
\hline 131 & $08 / 28 / 12$ & SC & C & $H \& L$ & $\mathrm{~F}$ & 755 & & & & & & \\
\hline 132 & $08 / 28 / 12$ & SC & C & $H \& L$ & M & 622 & & & & & 1 & \\
\hline 133 & $08 / 28 / 12$ & SC & C & $H \& L$ & $\mathrm{~F}$ & 833 & & & & & & \\
\hline 134 & $08 / 28 / 12$ & SC & C & $H \& L$ & $\mathrm{~F}$ & 806 & & & & & 1 & \\
\hline 135 & $08 / 28 / 12$ & SC & C & $H \& L$ & $\mathrm{~F}$ & 733 & & & & & & \\
\hline 136 & $08 / 28 / 12$ & SC & C & $H \& L$ & M & 732 & & & & & 1 & \\
\hline 137 & $08 / 28 / 12$ & SC & C & $H \& L$ & M & 783 & & & & & 1 & \\
\hline 138 & $08 / 28 / 12$ & SC & C & $H \& L$ & $\mathrm{~F}$ & 731 & & & & & & \\
\hline 139 & $08 / 28 / 12$ & SC & C & $H \& L$ & $\mathrm{~F}$ & 583 & & & & & & \\
\hline 140 & 08/28/12 & SC & C & $H \& L$ & M & 544 & 7 & & 37.5 & 16.3 & 1 & \\
\hline 141 & $08 / 28 / 12$ & SC & $\mathrm{R}$ & $H \& L$ & M & 561 & 9 & & 8.2 & 13.0 & 1 & \\
\hline 142 & $08 / 31 / 12$ & SC & $\mathrm{R}$ & $H \& L$ & M & 691 & 7 & & & 51.3 & 1 & \\
\hline 143 & $08 / 31 / 12$ & SC & $\mathrm{R}$ & $H \& L$ & M & 812 & 15 & & 52.7 & 62.1 & 1 & \\
\hline 144 & $08 / 31 / 12$ & SC & $\mathrm{R}$ & $\mathrm{H} \& \mathrm{~L}$ & M & 669 & 7 & & 24.8 & 40.1 & 1 & \\
\hline 145 & $08 / 31 / 12$ & SC & $\mathrm{R}$ & $H \& L$ & M & 650 & 9 & & 31.8 & 21.7 & 1 & \\
\hline 146 & 09/02/12 & SC & $\mathrm{R}$ & $\mathrm{H} \& \mathrm{~L}$ & $\mathrm{~F}$ & 832 & & & & & & \\
\hline 147 & 09/02/12 & SC & $\mathrm{R}$ & $\mathrm{H} \& \mathrm{~L}$ & $\mathrm{~F}$ & 861 & & & & & 1 & \\
\hline 148 & 09/06/12 & MB & $\mathrm{R}$ & H\&L & $\mathrm{F}$ & 876 & 8 & & 194.8 & 123.6 & 1 & 4 \\
\hline 149 & 09/06/12 & MB & $\mathrm{R}$ & $H \& L$ & M & 667 & 7 & & 26.2 & 37.0 & 1 & \\
\hline 150 & 09/08/12 & PSL & $\mathrm{R}$ & $\mathrm{H} \& \mathrm{~L}$ & $\mathrm{~F}$ & 671 & 9 & & 39.9 & 55.4 & 0 & 2 \\
\hline
\end{tabular}




\begin{tabular}{|c|c|c|c|c|c|c|c|c|c|c|c|c|}
\hline No. & Date & Site & Fishery & $\begin{array}{l}\text { Gear } \\
\text { Type }\end{array}$ & Sex & $\begin{array}{l}\text { Length } \\
(\mathrm{mm})^{1}\end{array}$ & $\begin{array}{l}\text { Age } \\
(\mathrm{yr})\end{array}$ & $\begin{array}{c}\text { Body } \\
\text { Mass (g) }\end{array}$ & $\begin{array}{c}\text { Gonad } \\
\text { Mass (g) }\end{array}$ & $\begin{array}{c}\text { Liver } \\
\text { Mass (g) }\end{array}$ & $\begin{array}{c}\text { Macro } \\
\text { Mat }\end{array}$ & $\begin{array}{c}\text { Micro } \\
\text { Mat }\end{array}$ \\
\hline 151 & $09 / 18 / 12$ & PSL & $\mathrm{R}$ & $\mathrm{H} \& \mathrm{~L}$ & $\mathrm{~F}$ & 910 & 9 & & & & 0 & 1 or 6 \\
\hline 152 & 09/18/12 & PSL & $\mathrm{R}$ & $H \& L$ & $\mathrm{~F}$ & 823 & 5 & & & & 0 & \\
\hline 153 & $09 / 21 / 12$ & $\mathrm{SC}$ & $\mathrm{R}$ & $H \& L$ & M & 593 & 5 & & & & & \\
\hline 154 & $09 / 21 / 12$ & SC & $\mathrm{R}$ & $H \& L$ & $\mathrm{~F}$ & 742 & 7 & & 152.1 & & 1 & \\
\hline 155 & $05 / 11 / 13$ & MB & $\mathrm{R}$ & $H \& L$ & M & 832 & 9 & 7200 & 169.6 & & 1 & \\
\hline 156 & $05 / 11 / 13$ & MB & $\mathrm{R}$ & $H \& L$ & M & 830 & 8 & 6500 & 198.9 & 45.9 & 1 & \\
\hline 157 & $05 / 27 / 13$ & SC & $\mathrm{R}$ & $H \& L$ & $\mathrm{~F}$ & 895 & 10 & 9400 & 243.3 & 116.0 & 1 & 3 \\
\hline 158 & $06 / 11 / 13$ & SC & $\mathrm{R}$ & $H \& L$ & M & 688 & 8 & 4167 & 67.0 & 29.9 & 1 & \\
\hline 159 & $06 / 14 / 13$ & SC & $\mathrm{R}$ & $H \& L$ & $\mathrm{~F}$ & 922 & 8 & 9809 & 153.0 & 141.4 & 0 & 2 \\
\hline 160 & $06 / 14 / 13$ & MT & $\mathrm{R}$ & SP & $\mathrm{F}$ & 1024 & & 11255 & 190.2 & 97.3 & 0 & 2 \\
\hline 161 & $06 / 15 / 13$ & SC & $\mathrm{R}$ & $H \& L$ & $\mathrm{~F}$ & 830 & 7 & & & 83.7 & 1 & \\
\hline 162 & $06 / 16 / 13$ & $\mathrm{ML}$ & & $H \& L$ & $\mathrm{~F}$ & & & 8420 & & & & \\
\hline 163 & $06 / 16 / 13$ & $M L$ & & $H \& L$ & $\mathrm{~F}$ & & & 8647 & & & & \\
\hline 164 & $06 / 16 / 13$ & $M L$ & & $H \& L$ & $\mathrm{~F}$ & & & 9384 & & & & \\
\hline 165 & $06 / 16 / 13$ & $\mathrm{ML}$ & & $H \& L$ & $\mathrm{~F}$ & & & 9923 & & & & \\
\hline 166 & $06 / 16 / 13$ & ML & & $\mathrm{H} \& \mathrm{~L}$ & $\mathrm{~F}$ & & & 10631 & & & & \\
\hline 167 & $06 / 16 / 13$ & ML & & $H \& L$ & M & & & 5585 & & & 1 & \\
\hline 168 & $06 / 16 / 13$ & ML & C & $H \& L$ & $\mathrm{~F}$ & 918 & 8 & 9157 & 282.3 & 164.3 & 1 & 3 \\
\hline 169 & $06 / 21 / 13$ & SC & $\mathrm{R}$ & $H \& L$ & M & 561 & 6 & & 37.1 & 24.8 & 1 & \\
\hline 170 & $06 / 21 / 13$ & SC & $\mathrm{R}$ & $H \& L$ & M & 714 & 8 & & 146.0 & 32.3 & 1 & \\
\hline 171 & $06 / 22 / 13$ & ML & & $H \& L$ & $\mathrm{~F}$ & & & 3515 & & & & \\
\hline 172 & $06 / 22 / 13$ & ML & & $H \& L$ & M & & & 3062 & & & 1 & \\
\hline 173 & $06 / 22 / 13$ & $M L$ & & $H \& L$ & M & & & 3600 & & & 1 & \\
\hline 174 & $06 / 22 / 13$ & ML & & $H \& L$ & M & & & 7000 & & & 1 & \\
\hline 175 & $06 / 22 / 13$ & $\mathrm{ML}$ & C & $H \& L$ & $\mathrm{~F}$ & 812 & 9 & & 263.0 & 107.9 & 1 & 4 \\
\hline 176 & $06 / 22 / 13$ & ML & $\mathrm{R}$ & $H \& L$ & $\mathrm{~F}$ & 900 & 8 & 9979 & 312.7 & 163.1 & 1 & 4 \\
\hline
\end{tabular}




\begin{tabular}{|c|c|c|c|c|c|c|c|c|c|c|c|c|}
\hline No. & Date & Site & Fishery & $\begin{array}{l}\text { Gear } \\
\text { Type }\end{array}$ & Sex & $\begin{array}{l}\text { Length } \\
(\mathrm{mm})^{1}\end{array}$ & $\begin{array}{l}\text { Age } \\
(\mathrm{yr})\end{array}$ & $\begin{array}{c}\text { Body } \\
\text { Mass (g) }\end{array}$ & $\begin{array}{c}\text { Gonad } \\
\text { Mass (g) }\end{array}$ & $\begin{array}{c}\text { Liver } \\
\text { Mass (g) }\end{array}$ & $\begin{array}{c}\text { Macro } \\
\text { Mat }\end{array}$ & $\begin{array}{l}\text { Micro } \\
\text { Mat }\end{array}$ \\
\hline 177 & $06 / 22 / 13$ & ML & & $\mathrm{H} \& \mathrm{~L}$ & M & 657 & 7 & 1758 & 72.4 & 19.6 & 1 & \\
\hline 178 & $06 / 22 / 13$ & $M L$ & C & $H \& L$ & M & 749 & 8 & & & & & \\
\hline 179 & $06 / 22 / 13$ & MT & & $H \& L$ & M & 775 & 8 & & 92.0 & 37.1 & 1 & \\
\hline 180 & $06 / 22 / 13$ & SC & $\mathrm{R}$ & $H \& L$ & $\mathrm{~F}$ & 660 & 4 & & 40.5 & 29.5 & 0 & 2 \\
\hline 181 & $06 / 23 / 13$ & SC & $\mathrm{R}$ & $H \& L$ & $\mathrm{~F}$ & & & 3515 & & & 1 & \\
\hline 182 & $06 / 23 / 13$ & SC & $\mathrm{R}$ & $H \& L$ & $\mathrm{~F}$ & 668 & 5 & 3657 & 121.2 & 37.2 & 1 & 4 \\
\hline 183 & $06 / 23 / 13$ & $M L$ & C & $H \& L$ & $\mathrm{~F}$ & 725 & 5 & 4536 & 245.9 & 69.6 & 1 & 4 \\
\hline 184 & $06 / 24 / 13$ & MT & $\mathrm{R}$ & SP & $\mathrm{F}$ & 907 & 8 & & & 164.8 & 1 & \\
\hline 185 & $06 / 25 / 13$ & ML & $\mathrm{R}$ & $H \& L$ & $\mathrm{~F}$ & & & 14203 & & & & \\
\hline 186 & $06 / 25 / 13$ & $M L$ & $\mathrm{R}$ & $H \& L$ & $\mathrm{~F}$ & 824 & 9 & 6719 & 313.8 & 111.8 & 1 & 3 \\
\hline 187 & $06 / 25 / 13$ & ML & $\mathrm{R}$ & $H \& L$ & M & 636 & 7 & 2693 & 83.8 & 18.1 & 1 & \\
\hline 188 & $06 / 25 / 13$ & ML & $\mathrm{R}$ & $H \& L$ & $\mathrm{~F}$ & 950 & 8 & 9809 & 737.2 & 230.0 & 1 & 4 \\
\hline 189 & $06 / 25 / 13$ & $M L$ & $\mathrm{R}$ & $H \& L$ & $\mathrm{~F}$ & 817 & 9 & 6521 & & 86.5 & 1 & 3 \\
\hline 190 & $06 / 26 / 13$ & SC & $\mathrm{R}$ & $H \& L$ & M & 710 & 14 & & 138.8 & 33.1 & 1 & \\
\hline 191 & $06 / 26 / 13$ & SC & $\mathrm{R}$ & $H \& L$ & $\mathrm{~F}$ & 786 & 9 & & 275.6 & 98.6 & 1 & 4 \\
\hline 192 & $06 / 28 / 13$ & SC & $\mathrm{R}$ & $H \& L$ & $\mathrm{~F}$ & 846 & 8 & & & & $\mathrm{~F}$ & 3 \\
\hline 193 & $06 / 28 / 13$ & $M L$ & $\mathrm{R}$ & $H \& L$ & M & 698 & 8 & & 107.7 & 35.6 & 1 & \\
\hline 194 & $06 / 28 / 13$ & ML & $\mathrm{R}$ & $H \& L$ & M & 659 & 7 & & 96.4 & 20.9 & 1 & \\
\hline 195 & $06 / 30 / 13$ & SC & $\mathrm{R}$ & $H \& L$ & M & 611 & 8 & 2637 & 72.9 & 18.0 & 1 & \\
\hline 196 & $07 / 01 / 13$ & SC & $\mathrm{R}$ & $H \& L$ & $\mathrm{~F}$ & 783 & 8 & 5557 & 99.1 & 76.5 & 0 & 5 \\
\hline 197 & 07/01/13 & SC & $\mathrm{R}$ & $H \& L$ & $\mathrm{~F}$ & 759 & 8 & & 194.7 & 53.8 & 1 & 4 \\
\hline 198 & $07 / 02 / 13$ & ML & $\mathrm{R}$ & $H \& L$ & M & 763 & 9 & 5046 & 139.8 & 50.6 & 1 & \\
\hline 199 & $07 / 02 / 13$ & $M L$ & $\mathrm{R}$ & $H \& L$ & M & 635 & 8 & 2807 & 111.6 & 32.8 & 1 & \\
\hline 200 & $07 / 02 / 13$ & ML & $\mathrm{R}$ & $H \& L$ & $\mathrm{~F}$ & 834 & 8 & 6549 & 337.8 & & 1 & 3 \\
\hline 201 & $07 / 02 / 13$ & ML & $\mathrm{R}$ & $\mathrm{H} \& \mathrm{~L}$ & M & 773 & 9 & 5131 & 136.6 & 52.0 & 1 & \\
\hline 202 & $07 / 02 / 13$ & $M L$ & $\mathrm{R}$ & $H \& L$ & $\mathrm{~F}$ & 1016 & 14 & 11255 & 458.9 & & 1 & 3 \\
\hline
\end{tabular}




\begin{tabular}{|c|c|c|c|c|c|c|c|c|c|c|c|c|}
\hline No. & Date & Site & Fishery & $\begin{array}{l}\text { Gear } \\
\text { Type }\end{array}$ & Sex & $\begin{array}{l}\text { Length } \\
(\mathrm{mm})^{1}\end{array}$ & $\begin{array}{l}\text { Age } \\
(\mathrm{yr})\end{array}$ & $\begin{array}{c}\text { Body } \\
\text { Mass (g) }\end{array}$ & $\begin{array}{c}\text { Gonad } \\
\text { Mass (g) }\end{array}$ & $\begin{array}{c}\text { Liver } \\
\text { Mass (g) }\end{array}$ & $\begin{array}{c}\text { Macro } \\
\text { Mat }\end{array}$ & $\begin{array}{l}\text { Micro } \\
\text { Mat }\end{array}$ \\
\hline 203 & $07 / 02 / 13$ & ML & $\mathrm{R}$ & $H \& L$ & M & 821 & 8 & 5868 & 205.2 & 53.3 & 1 & \\
\hline 204 & $07 / 05 / 13$ & SC & $\mathrm{R}$ & $H \& L$ & $\mathrm{~F}$ & 600 & 6 & 2325 & 131.0 & 49.7 & 1 & 3 \\
\hline 205 & $07 / 06 / 13$ & SC & $\mathrm{R}$ & $H \& L$ & $\mathrm{~F}$ & 743 & 7 & 4423 & 235.1 & 67.0 & 1 & 3 \\
\hline 206 & 07/06/13 & SC & $\mathrm{R}$ & $H \& L$ & $\mathrm{~F}$ & 947 & 7 & 10631 & 193.1 & 141.8 & 1 & 3 \\
\hline 207 & $07 / 06 / 13$ & SC & $\mathrm{R}$ & $H \& L$ & M & 797 & 9 & & 196.4 & 35.7 & 1 & \\
\hline 208 & $07 / 06 / 13$ & SC & $\mathrm{R}$ & $H \& L$ & $\mathrm{~F}$ & 873 & 9 & 7768 & 426.9 & 134.1 & 1 & 4 \\
\hline 209 & $07 / 06 / 13$ & SC & $\mathrm{R}$ & $H \& L$ & $\mathrm{~F}$ & 850 & 6 & & 401.9 & 97.8 & 1 & 4 \\
\hline 210 & $07 / 06 / 13$ & SC & $\mathrm{R}$ & $H \& L$ & M & 620 & 8 & & 43.2 & 18.2 & 1 & \\
\hline 211 & $07 / 07 / 13$ & ML & & $H \& L$ & $\mathrm{~F}$ & & & 4678 & & & & \\
\hline 212 & $07 / 07 / 13$ & ML & & $H \& L$ & $\mathrm{~F}$ & & & 3459 & & & & \\
\hline 213 & $07 / 07 / 13$ & ML & & $H \& L$ & M & & & 2041 & & & 1 & \\
\hline 214 & $07 / 07 / 13$ & ML & & $H \& L$ & M & & & 3260 & & & 1 & \\
\hline 215 & $07 / 07 / 13$ & ML & & $H \& L$ & M & & & & & & 1 & \\
\hline 216 & $07 / 07 / 13$ & $M L$ & & $H \& L$ & M & & & & & & 1 & \\
\hline 217 & 07/07/13 & SC & $\mathrm{R}$ & $H \& L$ & $\mathrm{~F}$ & 872 & 9 & & 142.6 & 72.6 & 0 & 2 \\
\hline 218 & $07 / 07 / 13$ & SC & $\mathrm{R}$ & $\mathrm{H} \& \mathrm{~L}$ & M & 540 & 7 & 1814 & 64.7 & 17.9 & 1 & \\
\hline 219 & $07 / 07 / 13$ & SC & $\mathrm{R}$ & $H \& L$ & M & 809 & & & 139.9 & 39.3 & 1 & \\
\hline 220 & $07 / 07 / 13$ & SC & $\mathrm{R}$ & $H \& L$ & M & 768 & 14 & 5188 & 105.2 & 46.2 & 0 & \\
\hline 221 & $07 / 10 / 13$ & MT & $\mathrm{R}$ & $H \& L$ & M & 842 & 10 & 7428 & 223.7 & 55.6 & 1 & \\
\hline 222 & $07 / 10 / 13$ & MT & $\mathrm{R}$ & $\mathrm{H} \& \mathrm{~L}$ & M & 860 & 6 & 7399 & 220.4 & 59.9 & 1 & \\
\hline 223 & 07/10/13 & ML & $\mathrm{R}$ & SP & $\mathrm{F}$ & 767 & 7 & & 191.9 & 92.0 & 1 & 3 \\
\hline 224 & $07 / 12 / 13$ & MB & $\mathrm{R}$ & $\mathrm{H} \& \mathrm{~L}$ & $\mathrm{~F}$ & 1035 & 10 & 13750 & 697.7 & 266.3 & 1 & 3 \\
\hline 225 & $07 / 12 / 13$ & MB & $\mathrm{R}$ & $\mathrm{H} \& \mathrm{~L}$ & $\mathrm{~F}$ & 894 & 8 & 9100 & 608.1 & 162.5 & 1 & 4 \\
\hline 226 & $07 / 12 / 13$ & MB & & $H \& L$ & $\mathrm{~F}$ & 685 & 4 & 3912 & 253.0 & 69.3 & 1 & 4 \\
\hline 227 & $07 / 12 / 13$ & ML & C & $\mathrm{H} \& \mathrm{~L}$ & $\mathrm{~F}$ & 690 & 8 & & & 77.4 & 1 & \\
\hline 228 & $07 / 12 / 13$ & $M L$ & C & $H \& L$ & M & 651 & 7 & & 181.1 & 40.6 & 1 & \\
\hline
\end{tabular}




\begin{tabular}{|c|c|c|c|c|c|c|c|c|c|c|c|c|}
\hline No. & Date & Site & Fishery & $\begin{array}{l}\text { Gear } \\
\text { Type }\end{array}$ & Sex & $\begin{array}{l}\text { Length } \\
(\mathrm{mm})^{1}\end{array}$ & $\begin{array}{l}\text { Age } \\
(\mathrm{yr})\end{array}$ & $\begin{array}{c}\text { Body } \\
\text { Mass (g) }\end{array}$ & $\begin{array}{c}\text { Gonad } \\
\text { Mass (g) }\end{array}$ & $\begin{array}{c}\text { Liver } \\
\text { Mass (g) }\end{array}$ & $\begin{array}{c}\text { Macro } \\
\text { Mat }\end{array}$ & $\begin{array}{l}\text { Micro } \\
\text { Mat }\end{array}$ \\
\hline 229 & $07 / 12 / 13$ & ML & C & $H \& L$ & M & 611 & 8 & & 71.4 & 20.2 & 1 & \\
\hline 230 & $07 / 12 / 13$ & ML & C & $H \& L$ & M & 619 & 7 & & 106.5 & 24.2 & 1 & \\
\hline 231 & $07 / 12 / 13$ & $M L$ & C & $H \& L$ & $\mathrm{~F}$ & 611 & 6 & & & 44.4 & 1 & \\
\hline 232 & $07 / 12 / 13$ & $M L$ & C & $H \& L$ & M & 624 & 7 & & & 16.8 & 1 & \\
\hline 233 & $07 / 12 / 13$ & ML & C & $H \& L$ & M & 699 & 8 & & 72.7 & 35.4 & 1 & \\
\hline 234 & $07 / 13 / 13$ & MB & $\mathrm{R}$ & & $\mathrm{F}$ & 1171 & 19 & & & & 1 & \\
\hline 235 & $07 / 13 / 13$ & MB & $\mathrm{R}$ & & $\mathrm{F}$ & 871 & 9 & & & & 0 & \\
\hline 236 & $07 / 13 / 13$ & MB & & & $\mathrm{F}$ & 962 & 9 & & & & 1 & \\
\hline 237 & $07 / 13 / 13$ & MB & $\mathrm{R}$ & $H \& L$ & $\mathrm{~F}$ & 835 & 8 & 6832 & 245.9 & 118.4 & 1 & 3 \\
\hline 238 & 07/13/13 & $M L$ & C & $H \& L$ & $\mathrm{~F}$ & 928 & 9 & & 446.9 & 198.9 & 1 & 3 \\
\hline 239 & $07 / 13 / 13$ & MB & $\mathrm{R}$ & & $\mathrm{F}$ & 789 & 8 & & & & 1 & \\
\hline 240 & $07 / 13 / 13$ & SC & $\mathrm{R}$ & $H \& L$ & $\mathrm{~F}$ & 607 & 5 & & & 27.3 & 0 & \\
\hline 241 & $07 / 13 / 13$ & ML & $\mathrm{R}$ & SP & $\mathrm{F}$ & 983 & 9 & 11567 & 554.8 & 144.5 & 1 & 3 \\
\hline 242 & $07 / 13 / 13$ & ML & $\mathrm{R}$ & SP & $\mathrm{F}$ & 806 & 10 & 6095 & & 103.5 & 1 & 3 \\
\hline 243 & 07/13/13 & $M L$ & $\mathrm{R}$ & SP & $\mathrm{F}$ & 1011 & 8 & 11964 & 620.4 & 168.4 & 1 & 3 \\
\hline 244 & $07 / 13 / 13$ & ML & $\mathrm{R}$ & SP & M & 781 & 8 & 5585 & 211.4 & 50.8 & 1 & \\
\hline 245 & $07 / 13 / 13$ & $M L$ & $\mathrm{R}$ & SP & M & 840 & 8 & 6549 & 211.9 & 64.0 & 1 & \\
\hline 246 & $07 / 13 / 13$ & ML & $\mathrm{R}$ & SP & $\mathrm{F}$ & 691 & 4 & 3799 & 177.3 & & 1 & 3 \\
\hline 247 & $07 / 13 / 13$ & SC & $\mathrm{R}$ & $H \& L$ & $\mathrm{~F}$ & 857 & 8 & & 254.3 & 86.3 & 1 & 3 \\
\hline 248 & $07 / 13 / 13$ & SC & $\mathrm{R}$ & $H \& L$ & $\mathrm{~F}$ & 774 & 7 & 4621 & & 78.2 & 1 & \\
\hline 249 & $07 / 13 / 13$ & ML & & $H \& L$ & $\mathrm{~F}$ & 826 & 8 & & 139.5 & & 1 & 3 \\
\hline 250 & $07 / 14 / 13$ & MB & & $\mathrm{H} \& \mathrm{~L}$ & M & 796 & 10 & 5642 & 103.4 & 44.0 & 1 & \\
\hline 251 & $07 / 14 / 13$ & MB & $\mathrm{R}$ & & $\mathrm{F}$ & 861 & 7 & & & & 1 & \\
\hline 252 & $07 / 14 / 13$ & MB & $\mathrm{R}$ & & $\mathrm{F}$ & 860 & 9 & & 255.1 & 82.6 & 1 & 3 \\
\hline 253 & $07 / 14 / 13$ & MTB & C & $\mathrm{H} \& \mathrm{~L}$ & M & 765 & 15 & & 191.0 & 45.2 & 1 & \\
\hline 254 & $07 / 14 / 13$ & $\mathrm{ML}$ & C & $H \& L$ & M & 696 & 7 & & 151.5 & 29.2 & 1 & \\
\hline
\end{tabular}




\begin{tabular}{|c|c|c|c|c|c|c|c|c|c|c|c|c|}
\hline No. & Date & Site & Fishery & $\begin{array}{l}\text { Gear } \\
\text { Type }\end{array}$ & Sex & $\begin{array}{l}\text { Length } \\
(\mathrm{mm})^{1}\end{array}$ & $\begin{array}{l}\text { Age } \\
(\mathrm{yr})\end{array}$ & $\begin{array}{c}\text { Body } \\
\text { Mass (g) }\end{array}$ & $\begin{array}{c}\text { Gonad } \\
\text { Mass (g) }\end{array}$ & $\begin{array}{c}\text { Liver } \\
\text { Mass (g) }\end{array}$ & $\begin{array}{c}\text { Macro } \\
\text { Mat }\end{array}$ & $\begin{array}{l}\text { Micro } \\
\text { Mat }\end{array}$ \\
\hline 255 & $07 / 15 / 13$ & ML & $\mathrm{R}$ & $\mathrm{SP}$ & $\mathrm{F}$ & 1019 & 8 & & 949.6 & 351.9 & 1 & \\
\hline 256 & $07 / 15 / 13$ & ML & C & & $\mathrm{F}$ & 1010 & 10 & & 518.1 & & 1 & 4 \\
\hline 257 & $07 / 15 / 13$ & $M L$ & $\mathrm{R}$ & SP & $\mathrm{F}$ & 753 & 4 & & 234.9 & 89.9 & 1 & 3 \\
\hline 258 & $07 / 15 / 13$ & $M L$ & $\mathrm{R}$ & SP & $\mathrm{F}$ & 832 & 9 & & 475.4 & 137.1 & 1 & 3 \\
\hline 259 & $07 / 15 / 13$ & ML & $\mathrm{R}$ & SP & $\mathrm{F}$ & 920 & 8 & & 422.1 & 153.2 & 1 & \\
\hline 260 & $07 / 15 / 13$ & ML & $\mathrm{R}$ & SP & $\mathrm{F}$ & 905 & 9 & & & & & \\
\hline 261 & $07 / 15 / 13$ & ML & $\mathrm{R}$ & SP & M & 732 & 8 & & 185.2 & 33.4 & 1 & \\
\hline 262 & $07 / 16 / 13$ & MT & $\mathrm{R}$ & $H \& L$ & M & 850 & 8 & 7173 & 168.1 & 63.0 & 1 & \\
\hline 263 & $07 / 16 / 13$ & MT & $\mathrm{R}$ & $H \& L$ & $\mathrm{~F}$ & 921 & 8 & 10688 & 534.1 & 184.3 & 1 & 3 \\
\hline 264 & 07/16/13 & MT & $\mathrm{R}$ & $H \& L$ & $\mathrm{~F}$ & 838 & 9 & 7343 & 347.1 & 113.0 & 1 & 4 \\
\hline 265 & $07 / 16 / 13$ & MT & $\mathrm{R}$ & $H \& L$ & M & 758 & 7 & 4678 & 87.7 & 34.5 & 1 & \\
\hline 266 & $07 / 16 / 13$ & ML & $\mathrm{R}$ & SP & $\mathrm{F}$ & 789 & 7 & 5600 & 456.4 & 144.3 & 1 & 4 \\
\hline 267 & $07 / 16 / 13$ & ML & $\mathrm{R}$ & SP & $\mathrm{F}$ & 1020 & 12 & 13100 & 268.8 & 255.2 & 1 & 3 \\
\hline 268 & $07 / 16 / 13$ & $\mathrm{ML}$ & $\mathrm{R}$ & SP & $\mathrm{F}$ & 859 & 7 & 7399 & 391.4 & 144.1 & 1 & 3 \\
\hline 269 & $07 / 17 / 13$ & SC & $\mathrm{R}$ & $H \& L$ & $\mathrm{~F}$ & 1090 & 15 & & & 185.8 & 1 & 3 \\
\hline 270 & $07 / 19 / 13$ & ML & $\mathrm{R}$ & SP & $\mathrm{F}$ & 908 & 8 & & 578.6 & 192.6 & 1 & 4 \\
\hline 271 & $07 / 19 / 13$ & SC & $\mathrm{R}$ & $H \& L$ & $\mathrm{~F}$ & 803 & 8 & & 213.3 & 75.5 & 1 & 3 \\
\hline 272 & $07 / 19 / 13$ & SC & C & $H \& L$ & M & 625 & 7 & 2835 & 90.9 & 22.4 & 1 & \\
\hline 273 & $07 / 19 / 13$ & SC & C & $H \& L$ & M & 603 & 7 & 2381 & 79.4 & 17.4 & 1 & \\
\hline 274 & $07 / 19 / 13$ & SC & C & $\mathrm{H} \& \mathrm{~L}$ & M & 680 & 8 & 3090 & 75.3 & 21.3 & 1 & \\
\hline 275 & 07/19/13 & SC & C & $H \& L$ & M & 721 & 8 & 4423 & 136.9 & 42.8 & 1 & \\
\hline 276 & 07/19/13 & SC & C & $\mathrm{H} \& \mathrm{~L}$ & $\mathrm{~F}$ & 671 & 4 & 3572 & 137.4 & 52.5 & 1 & \\
\hline 277 & 07/19/13 & SC & C & $\mathrm{H} \& \mathrm{~L}$ & M & 616 & 8 & 2750 & 95.1 & 23.7 & 1 & \\
\hline 278 & 07/19/13 & SC & C & $\mathrm{H} \& \mathrm{~L}$ & M & 556 & 3 & 1729 & 45.8 & 15.9 & 1 & \\
\hline 279 & 07/19/13 & SC & C & $H \& L$ & $\mathrm{~F}$ & 816 & 9 & 6634 & & 106.3 & 1 & \\
\hline 280 & $07 / 19 / 13$ & SC & C & $H \& L$ & M & 849 & 10 & 6974 & 155.8 & 79.6 & 1 & \\
\hline
\end{tabular}




\begin{tabular}{|c|c|c|c|c|c|c|c|c|c|c|c|c|}
\hline No. & Date & Site & Fishery & $\begin{array}{l}\text { Gear } \\
\text { Type }\end{array}$ & Sex & $\begin{array}{l}\text { Length } \\
(\mathrm{mm})^{1}\end{array}$ & $\begin{array}{l}\text { Age } \\
(\mathrm{yr})\end{array}$ & $\begin{array}{c}\text { Body } \\
\text { Mass (g) }\end{array}$ & $\begin{array}{c}\text { Gonad } \\
\text { Mass (g) }\end{array}$ & $\begin{array}{c}\text { Liver } \\
\text { Mass (g) }\end{array}$ & $\begin{array}{c}\text { Macro } \\
\text { Mat }\end{array}$ & $\begin{array}{c}\text { Micro } \\
\text { Mat }\end{array}$ \\
\hline 281 & $07 / 19 / 13$ & ML & $\mathrm{R}$ & $\mathrm{SP}$ & $\mathrm{F}$ & 887 & 8 & & 371.3 & 135.1 & 1 & 3 \\
\hline 282 & 07/19/13 & $\mathrm{ML}$ & $\mathrm{R}$ & SP & $\mathrm{F}$ & 771 & 8 & & 293.4 & 123.6 & 1 & 3 \\
\hline 283 & 07/19/13 & SC & C & $H \& L$ & M & 752 & 8 & 4451 & 88.9 & 55.9 & 1 & \\
\hline 284 & 07/19/13 & SC & $C$ & $H \& L$ & M & 646 & 8 & 2778 & 84.8 & 26.2 & 1 & \\
\hline 285 & 07/19/13 & SC & C & $H \& L$ & $\mathrm{~F}$ & 838 & 9 & 6464 & 298.5 & 95.9 & 1 & 3 \\
\hline 286 & 07/19/13 & SC & C & $H \& L$ & $\mathrm{~F}$ & 835 & 7 & 6974 & 270.5 & 78.0 & 1 & \\
\hline 287 & 07/19/13 & SC & C & $\mathrm{H} \& \mathrm{~L}$ & $\mathrm{~F}$ & 835 & 7 & 6294 & 202.9 & 71.5 & 1 & 3 \\
\hline 288 & $07 / 20 / 13$ & $\mathrm{ML}$ & $\mathrm{R}$ & SP & $\mathrm{F}$ & & & 5528 & & & 1 & \\
\hline 289 & $07 / 20 / 13$ & ML & $\mathrm{R}$ & SP & $\mathrm{F}$ & & & 7456 & & & 1 & \\
\hline 290 & $07 / 20 / 13$ & $\mathrm{ML}$ & $\mathrm{R}$ & SP & $\mathrm{F}$ & & & 12672 & & & 1 & \\
\hline 291 & $07 / 20 / 13$ & PSL & $\mathrm{R}$ & $H \& L$ & $\mathrm{~F}$ & & & 11598 & & & 1 & \\
\hline 292 & $07 / 20 / 13$ & PSL & $\mathrm{R}$ & $H \& L$ & $\mathrm{~F}$ & & & 7149 & & & 0 & \\
\hline 293 & 07/20/13 & $\mathrm{ML}$ & $\mathrm{R}$ & SP & M & & & 5046 & & & 1 & \\
\hline 294 & $07 / 20 / 13$ & PSL & $\mathrm{R}$ & $H \& L$ & $\mathrm{~F}$ & 1031 & & 11822 & & & & \\
\hline 295 & 07/20/13 & PSL & $\mathrm{R}$ & $H \& L$ & $\mathrm{~F}$ & 1030 & 9 & 12077 & 137.5 & 169.4 & 0 & 2 \\
\hline 296 & $07 / 20 / 13$ & $\mathrm{ML}$ & C & $H \& L$ & M & 604 & 7 & & 98.3 & 23.6 & 1 & \\
\hline 297 & $07 / 20 / 13$ & $M L$ & C & & M & 675 & 8 & & 102.1 & 26.6 & 1 & \\
\hline 298 & $07 / 21 / 13$ & $\mathrm{ML}$ & $\mathrm{R}$ & SP & $\mathrm{F}$ & & & 8448 & & & & \\
\hline 299 & $07 / 21 / 13$ & ML & $\mathrm{R}$ & SP & $\mathrm{F}$ & & & 8278 & & & & \\
\hline 300 & $07 / 21 / 13$ & $\mathrm{ML}$ & $\mathrm{R}$ & SP & $\mathrm{F}$ & & & 9327 & & & & \\
\hline 301 & $07 / 21 / 13$ & $\mathrm{ML}$ & $\mathrm{R}$ & SP & $\mathrm{F}$ & & & 10291 & & & & \\
\hline 302 & $07 / 21 / 13$ & $\mathrm{ML}$ & $\mathrm{R}$ & SP & M & & & 5103 & & & 1 & \\
\hline 303 & $07 / 21 / 13$ & $\mathrm{ML}$ & $\mathrm{R}$ & SP & M & & & 6464 & & & 1 & \\
\hline 304 & $07 / 21 / 13$ & $\mathrm{ML}$ & $\mathrm{R}$ & SP & M & & & 2693 & & & 1 & \\
\hline 305 & $07 / 21 / 13$ & $M L$ & $\mathrm{R}$ & SP & M & & & 2778 & & & 1 & \\
\hline 306 & $07 / 21 / 13$ & PSL & & $H \& L$ & $\mathrm{~F}$ & 852 & 8 & 7626 & 471.5 & 155.0 & 1 & 4 \\
\hline
\end{tabular}




\begin{tabular}{|c|c|c|c|c|c|c|c|c|c|c|c|c|}
\hline No. & Date & Site & Fishery & $\begin{array}{l}\text { Gear } \\
\text { Type }\end{array}$ & Sex & $\begin{array}{l}\text { Length } \\
(\mathrm{mm})^{1}\end{array}$ & $\begin{array}{l}\text { Age } \\
(y r)\end{array}$ & $\begin{array}{c}\text { Body } \\
\text { Mass (g) }\end{array}$ & $\begin{array}{c}\text { Gonad } \\
\text { Mass }(\mathrm{g})\end{array}$ & $\begin{array}{c}\text { Liver } \\
\text { Mass (g) }\end{array}$ & $\begin{array}{c}\text { Macro } \\
\text { Mat }\end{array}$ & $\begin{array}{c}\text { Micro } \\
\text { Mat }\end{array}$ \\
\hline 307 & $07 / 23 / 13$ & MB & & $\mathrm{H} \& \mathrm{~L}$ & $\mathrm{~F}$ & & 8 & 10569 & & 241.9 & 0 & \\
\hline 308 & $07 / 23 / 13$ & $M L$ & $\mathrm{R}$ & $\mathrm{SP}$ & $\mathrm{F}$ & 855 & 8 & 7966 & 464.7 & 158.7 & 1 & 4 \\
\hline 309 & $07 / 24 / 13$ & SC & $\mathrm{R}$ & $H \& L$ & $\mathrm{~F}$ & 709 & 8 & & 41.1 & 43.5 & 1 & 3 \\
\hline 310 & $07 / 24 / 13$ & SC & $\mathrm{R}$ & $H \& L$ & M & 668 & 8 & & & 21.8 & 1 & \\
\hline 311 & $07 / 24 / 13$ & SC & C & $H \& L$ & $\mathrm{~F}$ & 981 & 8 & & 641.0 & 275.8 & 1 & \\
\hline 312 & $07 / 25 / 13$ & $M L$ & $\mathrm{R}$ & $H \& L$ & $\mathrm{~F}$ & & & 4678 & & & & \\
\hline 313 & $07 / 25 / 13$ & SC & C & $H \& L$ & $\mathrm{~F}$ & & & 5613 & & & & \\
\hline 314 & $07 / 25 / 13$ & SC & C & $H \& L$ & $\mathrm{~F}$ & & & 7626 & & & & \\
\hline 315 & $07 / 25 / 13$ & SC & C & $H \& L$ & $\mathrm{~F}$ & & & & & & & \\
\hline 316 & $07 / 25 / 13$ & SC & C & $H \& L$ & M & & & 4564 & & & 1 & \\
\hline 317 & $07 / 25 / 13$ & SC & C & $H \& L$ & M & & & 3544 & & & 1 & \\
\hline 318 & $07 / 25 / 13$ & SC & C & $H \& L$ & M & & & 3260 & & & 1 & \\
\hline 319 & $07 / 25 / 13$ & SC & C & $\mathrm{H} \& \mathrm{~L}$ & M & & & 3941 & & & 1 & \\
\hline 320 & $07 / 25 / 13$ & SC & C & $H \& L$ & M & & & 4394 & & & 1 & \\
\hline 321 & $07 / 25 / 13$ & SC & C & $H \& L$ & $\mathrm{~F}$ & & & 2183 & & & & \\
\hline 322 & $07 / 25 / 13$ & $\mathrm{ML}$ & $\mathrm{R}$ & SP & M & 716 & & 4026 & 190.6 & 38.2 & 1 & \\
\hline 323 & $07 / 25 / 13$ & $\mathrm{ML}$ & $\mathrm{R}$ & SP & M & 827 & 8 & 6691 & 292.0 & 53.9 & 1 & \\
\hline 324 & $07 / 25 / 13$ & $M L$ & $\mathrm{R}$ & SP & M & 725 & 7 & 4281 & 151.5 & 40.0 & 1 & \\
\hline 325 & $07 / 25 / 13$ & $\mathrm{ML}$ & $\mathrm{R}$ & SP & $\mathrm{F}$ & 905 & 9 & 9469 & 438.4 & 156.9 & 1 & 4 \\
\hline 326 & $07 / 25 / 13$ & SC & C & $H \& L$ & $\mathrm{~F}$ & 845 & 8 & 6776 & 367.4 & 140.6 & 1 & 3 \\
\hline 327 & $07 / 25 / 13$ & SC & C & $H \& L$ & $\mathrm{~F}$ & 950 & 19 & 10263 & 447.3 & 196.8 & 1 & 3 \\
\hline 328 & $07 / 25 / 13$ & SC & C & $\mathrm{H} \& \mathrm{~L}$ & $\mathrm{~F}$ & 892 & 9 & 8732 & 450.2 & 178.1 & 1 & 3 \\
\hline 329 & $07 / 25 / 13$ & SC & C & $H \& L$ & $\mathrm{~F}$ & 961 & 14 & & & 123.2 & 1 & \\
\hline 330 & $07 / 25 / 13$ & SC & C & $H \& L$ & $\mathrm{~F}$ & 953 & 10 & & 443.9 & 167.6 & 1 & 3 \\
\hline 331 & $07 / 27 / 13$ & SFB & C & & $\mathrm{F}$ & 956 & 10 & & & & 1 & \\
\hline 332 & $07 / 27 / 13$ & SFB & C & & $\mathrm{F}$ & 862 & & & & & 1 & \\
\hline
\end{tabular}




\begin{tabular}{|c|c|c|c|c|c|c|c|c|c|c|c|c|}
\hline No. & Date & Site & Fishery & $\begin{array}{l}\text { Gear } \\
\text { Type }\end{array}$ & Sex & $\begin{array}{l}\text { Length } \\
(\mathrm{mm})^{1}\end{array}$ & $\begin{array}{l}\text { Age } \\
(y r)\end{array}$ & $\begin{array}{c}\text { Body } \\
\text { Mass (g) }\end{array}$ & $\begin{array}{c}\text { Gonad } \\
\text { Mass }(\mathrm{g})\end{array}$ & $\begin{array}{c}\text { Liver } \\
\text { Mass (g) }\end{array}$ & $\begin{array}{c}\text { Macro } \\
\text { Mat }\end{array}$ & $\begin{array}{c}\text { Micro } \\
\text { Mat }\end{array}$ \\
\hline 333 & $07 / 27 / 13$ & ML & $\mathrm{R}$ & $\mathrm{H} \& \mathrm{~L}$ & M & & & 3402 & & & 1 & \\
\hline 334 & $07 / 27 / 13$ & PSL & $\mathrm{R}$ & $H \& L$ & $\mathrm{~F}$ & 745 & 9 & 4990 & 251.2 & 87.3 & 1 & 4 \\
\hline 335 & $07 / 27 / 13$ & PSL & $\mathrm{R}$ & $H \& L$ & $\mathrm{~F}$ & 840 & 6 & 7286 & 138.1 & 111.7 & 1 & 3 \\
\hline 336 & $07 / 27 / 13$ & $\mathrm{ML}$ & $\mathrm{R}$ & $H \& L$ & M & 797 & 8 & 7428 & 154.5 & 31.4 & 1 & \\
\hline 337 & $07 / 27 / 13$ & SC & $\mathrm{R}$ & $H \& L$ & M & 570 & 7 & & 90.5 & 15.7 & 1 & \\
\hline 338 & $07 / 28 / 13$ & PSL & $\mathrm{R}$ & SP & $\mathrm{F}$ & 610 & 4 & & 20.2 & 22.7 & 0 & 2 \\
\hline 339 & $07 / 28 / 13$ & $\mathrm{ML}$ & $\mathrm{R}$ & $\mathrm{H} \& \mathrm{~L}$ & $\mathrm{~F}$ & 929 & 9 & 9809 & & 156.7 & 1 & 4 \\
\hline 340 & $07 / 28 / 13$ & SC & $\mathrm{R}$ & $H \& L$ & $\mathrm{~F}$ & 618 & 6 & & 87.8 & 32.6 & 1 & 3 \\
\hline 341 & $07 / 28 / 13$ & SC & $\mathrm{R}$ & $H \& L$ & $\mathrm{~F}$ & 718 & 4 & 2637 & 151.4 & 50.7 & 1 & 3 \\
\hline 342 & $07 / 28 / 13$ & SC & $\mathrm{R}$ & $H \& L$ & $\mathrm{~F}$ & 809 & 8 & 6322 & 500.3 & 107.7 & 1 & 4 \\
\hline 343 & 07/29/13 & $\mathrm{ML}$ & $\mathrm{R}$ & $H \& L$ & $\mathrm{~F}$ & 820 & 8 & & 247.7 & 100.0 & 1 & 3 \\
\hline 344 & $07 / 29 / 13$ & ML & $\mathrm{R}$ & $H \& L$ & M & 766 & 8 & & 179.7 & 44.0 & 1 & \\
\hline 345 & $07 / 29 / 13$ & MT & & SE & $\mathrm{F}$ & 394 & 2 & 624 & 2.1 & 4.9 & 0 & 1 or 6 \\
\hline 346 & 07/29/13 & $\mathrm{ML}$ & $\mathrm{R}$ & $H \& L$ & M & 732 & 8 & & 202.0 & & 1 & \\
\hline 347 & 07/30/13 & $\mathrm{ML}$ & $\mathrm{R}$ & $H \& L$ & M & 815 & 8 & 5698 & 142.5 & 51.7 & 1 & \\
\hline 348 & 07/30/13 & ML & $\mathrm{R}$ & $H \& L$ & $\mathrm{~F}$ & 726 & 7 & 4309 & 205.2 & 89.4 & 1 & 4 \\
\hline 349 & 07/30/13 & $\mathrm{ML}$ & $\mathrm{R}$ & $H \& L$ & M & 669 & & 3430 & 111.9 & 31.7 & 1 & \\
\hline 350 & 07/30/13 & $\mathrm{ML}$ & $\mathrm{R}$ & $H \& L$ & M & 782 & 7 & 5301 & 229.2 & 62.5 & 1 & \\
\hline 351 & $07 / 30 / 13$ & $\mathrm{ML}$ & $\mathrm{R}$ & $H \& L$ & M & 751 & 8 & & 50.3 & 35.1 & & \\
\hline 352 & $07 / 31 / 13$ & SC & $\mathrm{R}$ & $H \& L$ & M & 680 & 8 & 3345 & 178.4 & 26.2 & 1 & \\
\hline 353 & $07 / 31 / 13$ & ML & C & H\&L & $\mathrm{F}$ & 999 & 8 & 11992 & 468.9 & 241.9 & 1 & 3 \\
\hline 354 & 08/01/13 & $\mathrm{ML}$ & C & $H \& L$ & $\mathrm{~F}$ & & & 5443 & & & & \\
\hline 355 & $08 / 01 / 13$ & $\mathrm{ML}$ & C & $H \& L$ & $\mathrm{~F}$ & & & 7484 & & & & \\
\hline 356 & 08/01/13 & $\mathrm{ML}$ & C & H\&L & $\mathrm{F}$ & & & 9044 & & & & \\
\hline 357 & 08/01/13 & ML & C & $H \& L$ & $\mathrm{~F}$ & & & 9356 & & & & \\
\hline 358 & $08 / 01 / 13$ & $\mathrm{ML}$ & C & $H \& L$ & $\mathrm{~F}$ & & & 10575 & & & 1 & \\
\hline
\end{tabular}




\begin{tabular}{|c|c|c|c|c|c|c|c|c|c|c|c|c|}
\hline No. & Date & Site & Fishery & $\begin{array}{l}\text { Gear } \\
\text { Type }\end{array}$ & Sex & $\begin{array}{l}\text { Length } \\
(\mathrm{mm})^{1}\end{array}$ & $\begin{array}{l}\text { Age } \\
(\mathrm{yr})\end{array}$ & $\begin{array}{c}\text { Body } \\
\text { Mass (g) }\end{array}$ & $\begin{array}{c}\text { Gonad } \\
\text { Mass (g) }\end{array}$ & $\begin{array}{c}\text { Liver } \\
\text { Mass (g) }\end{array}$ & $\begin{array}{c}\text { Macro } \\
\text { Mat }\end{array}$ & $\begin{array}{c}\text { Micro } \\
\text { Mat }\end{array}$ \\
\hline 359 & $08 / 01 / 13$ & ML & C & $H \& L$ & $\mathrm{~F}$ & & & 10886 & & & & \\
\hline 360 & $08 / 01 / 13$ & ML & C & $H \& L$ & $\mathrm{~F}$ & & & 3657 & & & & \\
\hline 361 & $08 / 01 / 13$ & $M L$ & C & $H \& L$ & $\mathrm{~F}$ & & & 4479 & & & 1 & \\
\hline 362 & $08 / 01 / 13$ & $\mathrm{ML}$ & C & $H \& L$ & $\mathrm{~F}$ & & & 4111 & & & & \\
\hline 363 & $08 / 01 / 13$ & ML & C & $H \& L$ & M & & & 4649 & & & 1 & \\
\hline 364 & $08 / 01 / 13$ & ML & C & $\mathrm{H} \& \mathrm{~L}$ & M & & & 4706 & & & 1 & \\
\hline 365 & $08 / 01 / 13$ & ML & C & $\mathrm{H} \& \mathrm{~L}$ & M & & & 5273 & & & 1 & \\
\hline 366 & $08 / 01 / 13$ & $M L$ & C & $H \& L$ & M & & & 5755 & & & 1 & \\
\hline 367 & $08 / 01 / 13$ & ML & C & $H \& L$ & M & & & 3033 & & & 1 & \\
\hline 368 & $08 / 01 / 13$ & ML & C & $H \& L$ & M & & & 3062 & & & 1 & \\
\hline 369 & $08 / 01 / 13$ & ML & C & $H \& L$ & M & & & 3771 & & & 1 & \\
\hline 370 & $08 / 01 / 13$ & ML & C & $H \& L$ & M & & & 4139 & & & 1 & \\
\hline 371 & $08 / 01 / 13$ & ML & C & $H \& L$ & $\mathrm{~F}$ & 831 & 8 & & 107.8 & 141.2 & 0 & 2 \\
\hline 372 & $08 / 01 / 13$ & SC & $\mathrm{R}$ & $H \& L$ & M & 644 & 5 & & & & & \\
\hline 373 & $08 / 01 / 13$ & $M L$ & C & $H \& L$ & $\mathrm{~F}$ & 802 & 9 & 6095 & 407.2 & 122.7 & 1 & 4 \\
\hline 374 & $08 / 01 / 13$ & ML & C & $\mathrm{H} \& \mathrm{~L}$ & $\mathrm{~F}$ & 1047 & 14 & 12219 & 626.9 & 211.5 & 1 & 4 \\
\hline 375 & $08 / 01 / 13$ & ML & C & $H \& L$ & $\mathrm{~F}$ & 1035 & 15 & & 468.2 & 185.0 & 1 & 3 \\
\hline 376 & $08 / 02 / 13$ & MT & $\mathrm{R}$ & $H \& L$ & $\mathrm{~F}$ & & & 7371 & & & & \\
\hline 377 & $08 / 02 / 13$ & MT & $\mathrm{R}$ & $H \& L$ & $\mathrm{~F}$ & & & 3969 & & & & \\
\hline 378 & $08 / 02 / 13$ & MT & $\mathrm{R}$ & $\mathrm{H} \& \mathrm{~L}$ & $\mathrm{~F}$ & & & 4026 & & & & \\
\hline 379 & $08 / 02 / 13$ & MB & $\mathrm{R}$ & $H \& L$ & $\mathrm{~F}$ & 841 & 8 & 7541 & 239.6 & 148.1 & 1 & 3 \\
\hline 380 & $08 / 02 / 13$ & MT & $\mathrm{R}$ & SP & $\mathrm{F}$ & 915 & 7 & 9072 & 550.9 & 173.9 & 1 & 4 \\
\hline 381 & $08 / 03 / 13$ & ML & $\mathrm{R}$ & $\mathrm{H} \& \mathrm{~L}$ & $\mathrm{~F}$ & & & 4536 & & & & \\
\hline 382 & 08/03/13 & MT & $\mathrm{R}$ & $\mathrm{H} \& \mathrm{~L}$ & $\mathrm{~F}$ & & & 9894 & & & 1 & \\
\hline 383 & $08 / 03 / 13$ & ML & $\mathrm{R}$ & $\mathrm{H} \& \mathrm{~L}$ & $\mathrm{~F}$ & & & & & & & \\
\hline 384 & $08 / 03 / 13$ & ML & $\mathrm{R}$ & $\mathrm{H} \& \mathrm{~L}$ & M & & & & & & 1 & \\
\hline
\end{tabular}




\begin{tabular}{|c|c|c|c|c|c|c|c|c|c|c|c|c|}
\hline No. & Date & Site & Fishery & $\begin{array}{l}\text { Gear } \\
\text { Type }\end{array}$ & Sex & $\begin{array}{l}\text { Length } \\
(\mathrm{mm})^{1}\end{array}$ & $\begin{array}{l}\text { Age } \\
(\mathrm{yr})\end{array}$ & $\begin{array}{c}\text { Body } \\
\text { Mass (g) }\end{array}$ & $\begin{array}{c}\text { Gonad } \\
\text { Mass (g) }\end{array}$ & $\begin{array}{c}\text { Liver } \\
\text { Mass (g) }\end{array}$ & $\begin{array}{c}\text { Macro } \\
\text { Mat }\end{array}$ & $\begin{array}{c}\text { Micro } \\
\text { Mat }\end{array}$ \\
\hline 385 & $08 / 03 / 13$ & ML & $\mathrm{R}$ & $H \& L$ & $\mathrm{~F}$ & & & & & & & \\
\hline 386 & $08 / 03 / 13$ & PSL & $\mathrm{R}$ & $H \& L$ & $\mathrm{~F}$ & 879 & 8 & 7995 & & 118.8 & 0 & 2 \\
\hline 387 & $08 / 03 / 13$ & $\mathrm{ML}$ & $\mathrm{R}$ & SP & $\mathrm{F}$ & 949 & 9 & & 476.6 & 145.9 & 1 & 3 \\
\hline 388 & $08 / 03 / 13$ & PSL & $\mathrm{R}$ & $H \& L$ & $\mathrm{~F}$ & 1087 & 18 & 14203 & 588.3 & 218.1 & 1 & 3 \\
\hline 389 & $08 / 03 / 13$ & PSL & $\mathrm{R}$ & $H \& L$ & $\mathrm{~F}$ & & & 14203 & & & & \\
\hline 390 & $08 / 03 / 13$ & $\mathrm{ML}$ & & $H \& L$ & M & 663 & 6 & & & 21.2 & 1 & \\
\hline 391 & $08 / 03 / 13$ & ML & & $H \& L$ & $\mathrm{~F}$ & 863 & 8 & & 360.1 & 96.2 & 1 & 4 \\
\hline 392 & $08 / 03 / 13$ & $M L$ & $\mathrm{R}$ & $H \& L$ & M & 806 & 8 & 5900 & 252.0 & 37.0 & 1 & \\
\hline 393 & 08/03/13 & SC & $\mathrm{R}$ & $H \& L$ & $\mathrm{~F}$ & 663 & 8 & & 71.3 & 31.8 & 1 & 3 \\
\hline 394 & 08/03/13 & MT & C & $H \& L$ & $\mathrm{~F}$ & 838 & 8 & & 607.7 & 125.3 & 1 & 4 \\
\hline 395 & $08 / 03 / 13$ & MT & C & $H \& L$ & $\mathrm{~F}$ & 817 & 7 & & 296.9 & 130.0 & 1 & 3 \\
\hline 396 & $08 / 04 / 13$ & SC & $\mathrm{R}$ & $H \& L$ & $\mathrm{~F}$ & & & 6237 & & & & \\
\hline 397 & $08 / 04 / 13$ & SC & $\mathrm{R}$ & $H \& L$ & M & 593 & & & & & 1 & \\
\hline 398 & $08 / 04 / 13$ & MT & $\mathrm{R}$ & SP & $\mathrm{F}$ & 1070 & 12 & 15819 & 836.1 & 302.7 & 1 & \\
\hline 399 & $08 / 04 / 13$ & MT & $\mathrm{R}$ & SP & $\mathrm{F}$ & 976 & 9 & 11340 & 539.8 & & 1 & 3 \\
\hline 400 & $08 / 04 / 13$ & MT & $\mathrm{R}$ & SP & $\mathrm{F}$ & 937 & 8 & 10093 & 427.7 & 210.7 & 1 & 3 \\
\hline 401 & $08 / 04 / 13$ & MT & $\mathrm{R}$ & SP & $\mathrm{F}$ & 891 & 8 & 7768 & 592.8 & 110.2 & 1 & 4 \\
\hline 402 & $08 / 04 / 13$ & MT & $\mathrm{R}$ & SP & $\mathrm{F}$ & 759 & 5 & 5018 & 199.2 & 84.4 & 1 & 3 \\
\hline 403 & $08 / 04 / 13$ & MT & $\mathrm{R}$ & SP & $\mathrm{F}$ & 792 & 8 & 5557 & 237.1 & & 1 & 3 \\
\hline 404 & $08 / 04 / 13$ & ML & $\mathrm{R}$ & $\mathrm{H} \& \mathrm{~L}$ & $\mathrm{~F}$ & 873 & 8 & 7995 & 349.8 & 155.3 & 1 & 4 \\
\hline 405 & $08 / 04 / 13$ & ML & $\mathrm{R}$ & $\mathrm{H} \& \mathrm{~L}$ & M & 752 & 8 & 4564 & 39.9 & 40.3 & 1 & \\
\hline 406 & 08/04/13 & ML & C & $\mathrm{H} \& \mathrm{~L}$ & $\mathrm{~F}$ & 797 & 9 & & 225.7 & 89.9 & 1 & 3 \\
\hline 407 & $08 / 04 / 13$ & $M L$ & $\mathrm{R}$ & $\mathrm{H} \& \mathrm{~L}$ & M & 662 & 8 & 4054 & 156.3 & 46.4 & 1 & \\
\hline 408 & $08 / 04 / 13$ & ML & $\mathrm{R}$ & $H \& L$ & $\mathrm{~F}$ & 900 & 8 & 8023 & 309.8 & 130.4 & 1 & 4 \\
\hline 409 & 08/06/13 & $M L$ & $\mathrm{R}$ & $\mathrm{H} \& \mathrm{~L}$ & M & 641 & 7 & & 126.0 & 21.4 & 1 & \\
\hline 410 & $08 / 06 / 13$ & ML & $\mathrm{R}$ & $H \& L$ & M & 642 & 5 & & 126.1 & 22.7 & 1 & \\
\hline
\end{tabular}




\begin{tabular}{|c|c|c|c|c|c|c|c|c|c|c|c|c|}
\hline No. & Date & Site & Fishery & $\begin{array}{l}\text { Gear } \\
\text { Type }\end{array}$ & Sex & $\begin{array}{l}\text { Length } \\
(\mathrm{mm})^{1}\end{array}$ & $\begin{array}{l}\text { Age } \\
(y r)\end{array}$ & $\begin{array}{c}\text { Body } \\
\text { Mass (g) }\end{array}$ & $\begin{array}{c}\text { Gonad } \\
\text { Mass }(\mathrm{g})\end{array}$ & $\begin{array}{c}\text { Liver } \\
\text { Mass (g) }\end{array}$ & $\begin{array}{c}\text { Macro } \\
\text { Mat }\end{array}$ & $\begin{array}{c}\text { Micro } \\
\text { Mat }\end{array}$ \\
\hline 411 & 08/06/13 & $\mathrm{ML}$ & $\mathrm{R}$ & SP & $\mathrm{F}$ & 895 & 8 & 8703 & 298.6 & 143.1 & 1 & 3 \\
\hline 412 & 08/06/13 & ML & $\mathrm{R}$ & SP & M & 827 & 9 & 5982 & 275.2 & 39.2 & 1 & \\
\hline 413 & 08/07/13 & $M L$ & C & $H \& L$ & $\mathrm{~F}$ & 678 & & & & & 0 & \\
\hline 414 & 08/07/13 & ML & C & $H \& L$ & $\mathrm{~F}$ & 708 & & & & & 1 & \\
\hline 415 & 08/07/13 & $M L$ & C & $H \& L$ & $\mathrm{~F}$ & 837 & & & & & 1 & \\
\hline 416 & 08/07/13 & $\mathrm{ML}$ & C & $H \& L$ & $\mathrm{~F}$ & 986 & & & & & & \\
\hline 417 & 08/07/13 & ML & C & $\mathrm{H} \& \mathrm{~L}$ & M & 548 & & & & & 1 & \\
\hline 418 & 08/07/13 & $\mathrm{ML}$ & C & $H \& L$ & M & 600 & & & & & 1 & \\
\hline 419 & 08/07/13 & ML & C & $H \& L$ & M & 615 & & & & & 1 & \\
\hline 420 & 08/07/13 & $\mathrm{ML}$ & C & $H \& L$ & M & 625 & & & & & 1 & \\
\hline 421 & 08/07/13 & $M L$ & C & $H \& L$ & M & 633 & & & & & 1 & \\
\hline 422 & 08/07/13 & ML & C & $H \& L$ & M & 653 & & & & & 1 & \\
\hline 423 & 08/07/13 & $\mathrm{ML}$ & C & $H \& L$ & M & 655 & & & & & 1 & \\
\hline 424 & 08/07/13 & $\mathrm{ML}$ & C & $H \& L$ & M & 676 & & & & & 1 & \\
\hline 425 & 08/07/13 & ML & C & $\mathrm{H} \& \mathrm{~L}$ & M & 687 & & & & & 1 & \\
\hline 426 & 08/07/13 & ML & C & $H \& L$ & M & 697 & & & & & 1 & \\
\hline 427 & 08/07/13 & ML & C & $H \& L$ & M & 745 & & & & & 1 & \\
\hline 428 & 08/07/13 & $\mathrm{ML}$ & C & $H \& L$ & M & 769 & & & & & 1 & \\
\hline 429 & 08/07/13 & ML & C & $H \& L$ & M & 795 & & & & & 1 & \\
\hline 430 & 08/07/13 & ML & C & $\mathrm{H} \& \mathrm{~L}$ & M & 802 & & & & & 1 & \\
\hline 431 & 08/07/13 & ML & C & $H \& L$ & M & 834 & & & & & 1 & \\
\hline 432 & 08/07/13 & ML & C & $H \& L$ & M & 842 & & & & & 1 & \\
\hline 433 & 08/07/13 & ML & $\mathrm{R}$ & $\mathrm{SP}$ & $\mathrm{F}$ & 947 & 10 & 10858 & 591.0 & 241.1 & 1 & 3 \\
\hline 434 & 08/07/13 & MT & C & $H \& L$ & $\mathrm{~F}$ & 942 & 8 & & 520.0 & 232.3 & 1 & \\
\hline 435 & 08/07/13 & MT & $\mathrm{R}$ & $H \& L$ & $\mathrm{~F}$ & 907 & 8 & 8200 & 192.4 & 113.3 & 1 & 3 \\
\hline 436 & $08 / 07 / 13$ & $\mathrm{ML}$ & $\mathrm{R}$ & $H \& L$ & $\mathrm{~F}$ & 950 & 8 & & & 201.5 & 1 & \\
\hline
\end{tabular}




\begin{tabular}{|c|c|c|c|c|c|c|c|c|c|c|c|c|}
\hline No. & Date & Site & Fishery & $\begin{array}{l}\text { Gear } \\
\text { Type }\end{array}$ & Sex & $\begin{array}{l}\text { Length } \\
(\mathrm{mm})^{1}\end{array}$ & $\begin{array}{l}\text { Age } \\
(\mathrm{yr})\end{array}$ & $\begin{array}{c}\text { Body } \\
\text { Mass (g) }\end{array}$ & $\begin{array}{c}\text { Gonad } \\
\text { Mass (g) }\end{array}$ & $\begin{array}{c}\text { Liver } \\
\text { Mass (g) }\end{array}$ & $\begin{array}{c}\text { Macro } \\
\text { Mat }\end{array}$ & $\begin{array}{c}\text { Micro } \\
\text { Mat }\end{array}$ \\
\hline 437 & $08 / 07 / 13$ & ML & $\mathrm{R}$ & $H \& L$ & $\mathrm{~F}$ & 882 & & & & 147.2 & 1 & \\
\hline 438 & $08 / 07 / 13$ & ML & $\mathrm{R}$ & $H \& L$ & $\mathrm{~F}$ & 813 & 8 & & & 110.2 & 1 & \\
\hline 439 & $08 / 07 / 13$ & $M L$ & $\mathrm{R}$ & $H \& L$ & $\mathrm{~F}$ & 821 & 8 & & 267.9 & 111.8 & 1 & \\
\hline 440 & 08/07/13 & $\mathrm{ML}$ & $\mathrm{R}$ & $H \& L$ & $\mathrm{~F}$ & 892 & 8 & & 469.7 & 141.6 & 1 & \\
\hline 441 & $08 / 07 / 13$ & ML & $\mathrm{R}$ & SP & $\mathrm{F}$ & 1073 & 15 & 14884 & 868.7 & 336.7 & 1 & \\
\hline 442 & $08 / 07 / 13$ & ML & $\mathrm{R}$ & SP & $\mathrm{F}$ & 973 & 8 & 10546 & 518.0 & 198.4 & 1 & 3 \\
\hline 443 & $08 / 07 / 13$ & ML & $\mathrm{R}$ & SP & $\mathrm{F}$ & 870 & 8 & 8080 & 355.1 & 166.1 & 1 & \\
\hline 444 & $08 / 07 / 13$ & $M L$ & $\mathrm{R}$ & SP & $\mathrm{F}$ & 848 & 5 & 6946 & 407.7 & 143.8 & 1 & 3 \\
\hline 445 & 08/07/13 & ML & $\mathrm{R}$ & SP & $\mathrm{F}$ & 938 & 7 & 10773 & 732.1 & 245.4 & 1 & 3 \\
\hline 446 & 08/07/13 & SC & $\mathrm{R}$ & $H \& L$ & M & 923 & 8 & & 1.8 & 88.8 & 0 & \\
\hline 447 & $08 / 08 / 13$ & $M L$ & C & $H \& L$ & $\mathrm{~F}$ & & & 6407 & & & & \\
\hline 448 & $08 / 08 / 13$ & ML & C & $H \& L$ & $\mathrm{~F}$ & & & 6804 & & & & \\
\hline 449 & $08 / 08 / 13$ & ML & C & $H \& L$ & $\mathrm{~F}$ & & & 8703 & & & & \\
\hline 450 & $08 / 08 / 13$ & ML & C & $H \& L$ & $\mathrm{~F}$ & & & 8817 & & & & \\
\hline 451 & $08 / 08 / 13$ & ML & C & $H \& L$ & $\mathrm{~F}$ & & & 9299 & & & & \\
\hline 452 & $08 / 08 / 13$ & ML & C & $\mathrm{H} \& \mathrm{~L}$ & $\mathrm{~F}$ & & & 9554 & & & & \\
\hline 453 & $08 / 08 / 13$ & $\mathrm{ML}$ & C & $H \& L$ & $\mathrm{~F}$ & & & 10093 & & & & \\
\hline 454 & $08 / 08 / 13$ & MTB & C & $H \& L$ & $\mathrm{~F}$ & & & 9554 & & & & \\
\hline 455 & $08 / 08 / 13$ & PSL & $\mathrm{R}$ & $H \& L$ & $\mathrm{~F}$ & 882 & 7 & & 317.1 & 182.8 & 1 & 4 \\
\hline 456 & $08 / 08 / 13$ & MT & $\mathrm{R}$ & $\mathrm{H} \& \mathrm{~L}$ & $\mathrm{~F}$ & 974 & 8 & 11340 & 724.2 & 187.8 & 1 & \\
\hline 457 & $08 / 08 / 13$ & MT & $\mathrm{R}$ & $H \& L$ & $\mathrm{~F}$ & 1080 & 12 & 15422 & 750.9 & 255.5 & 1 & 4 \\
\hline 458 & $08 / 08 / 13$ & SC & $\mathrm{R}$ & $\mathrm{H} \& \mathrm{~L}$ & $\mathrm{~F}$ & 775 & 8 & 5188 & 343.8 & 65.9 & 1 & 4 \\
\hline 459 & $08 / 09 / 13$ & ML & $\mathrm{R}$ & SP & $\mathrm{F}$ & & & 8392 & & & & \\
\hline 460 & $08 / 09 / 13$ & MB & $\mathrm{R}$ & SP & $\mathrm{F}$ & 818 & 9 & 6662 & 88.0 & 124.5 & 0 & 2 \\
\hline 461 & $08 / 09 / 13$ & PSL & $\mathrm{R}$ & $\mathrm{H} \& \mathrm{~L}$ & $\mathrm{~F}$ & & 9 & & 121.1 & 214.6 & 0 & 2 \\
\hline 462 & $08 / 09 / 13$ & SC & C & $\mathrm{H} \& \mathrm{~L}$ & $\mathrm{~F}$ & 950 & 9 & & 574.0 & 142.8 & 1 & 3 \\
\hline
\end{tabular}




\begin{tabular}{|c|c|c|c|c|c|c|c|c|c|c|c|c|}
\hline No. & Date & Site & Fishery & $\begin{array}{l}\text { Gear } \\
\text { Type }\end{array}$ & Sex & $\begin{array}{l}\text { Length } \\
(\mathrm{mm})^{1}\end{array}$ & $\begin{array}{l}\text { Age } \\
(\mathrm{yr})\end{array}$ & $\begin{array}{c}\text { Body } \\
\text { Mass (g) }\end{array}$ & $\begin{array}{c}\text { Gonad } \\
\text { Mass (g) }\end{array}$ & $\begin{array}{c}\text { Liver } \\
\text { Mass (g) }\end{array}$ & $\begin{array}{c}\text { Macro } \\
\text { Mat }\end{array}$ & $\begin{array}{c}\text { Micro } \\
\text { Mat }\end{array}$ \\
\hline 463 & $08 / 09 / 13$ & SC & C & $H \& L$ & $\mathrm{~F}$ & 930 & & & 436.9 & 218.1 & 1 & 3 \\
\hline 464 & $08 / 09 / 13$ & SC & C & $H \& L$ & $\mathrm{~F}$ & 831 & 7 & & 409.1 & 109.9 & 1 & 4 \\
\hline 465 & $08 / 09 / 13$ & MTB & C & $H \& L$ & M & 644 & 7 & & 43.7 & 27.8 & 1 & \\
\hline 466 & 08/09/13 & MTB & C & $H \& L$ & $\mathrm{~F}$ & 893 & 8 & & 583.4 & 201.3 & 1 & 4 \\
\hline 467 & $08 / 09 / 13$ & MTB & C & $H \& L$ & $\mathrm{~F}$ & 911 & 7 & & 604.9 & 213.8 & 1 & 4 \\
\hline 468 & $08 / 09 / 13$ & MTB & C & $H \& L$ & M & 729 & 7 & & 115.5 & 66.2 & 1 & \\
\hline 469 & $08 / 09 / 13$ & MTB & C & $H \& L$ & $\mathrm{~F}$ & 901 & 10 & & 385.9 & 154.3 & 1 & \\
\hline 470 & $08 / 10 / 13$ & MT & C & $H \& L$ & $\mathrm{~F}$ & & & 7343 & & & 1 & \\
\hline 471 & 08/10/13 & MT & C & $H \& L$ & $\mathrm{~F}$ & & & 9866 & & & 1 & \\
\hline 472 & $08 / 10 / 13$ & MT & C & $H \& L$ & $\mathrm{~F}$ & & & 2863 & & & 1 & \\
\hline 473 & $08 / 10 / 13$ & MT & C & $H \& L$ & $\mathrm{~F}$ & & & 4111 & & & 1 & \\
\hline 474 & $08 / 10 / 13$ & MT & C & $H \& L$ & M & & & 2835 & & & 1 & \\
\hline 475 & $08 / 11 / 13$ & ML & C & $H \& L$ & $\mathrm{~F}$ & & & 6889 & & & 1 & \\
\hline 476 & $08 / 11 / 13$ & MT & $\mathrm{R}$ & $H \& L$ & $\mathrm{~F}$ & & & 8789 & & & 1 & \\
\hline 477 & $08 / 11 / 13$ & ML & $\mathrm{R}$ & $\mathrm{H} \& \mathrm{~L}$ & $\mathrm{~F}$ & & & 9214 & & & 1 & \\
\hline 478 & $08 / 11 / 13$ & ML & C & $\mathrm{H} \& \mathrm{~L}$ & $\mathrm{~F}$ & & & 11624 & & & 1 & \\
\hline 479 & $08 / 11 / 13$ & ML & C & $H \& L$ & $\mathrm{~F}$ & & & 12077 & & & & \\
\hline 480 & $08 / 11 / 13$ & ML & C & $H \& L$ & M & & & 3147 & & & 1 & \\
\hline 481 & $08 / 11 / 13$ & ML & $\mathrm{R}$ & $H \& L$ & $\mathrm{~F}$ & 868 & 7 & & 289.4 & 189.1 & 1 & 4 \\
\hline 482 & $08 / 11 / 13$ & MT & $\mathrm{R}$ & $\mathrm{H} \& \mathrm{~L}$ & $\mathrm{~F}$ & 910 & 8 & & 433.9 & 177.0 & 1 & 3 \\
\hline 483 & $08 / 11 / 13$ & ML & $\mathrm{R}$ & $H \& L$ & $\mathrm{~F}$ & 694 & 8 & & & 50.4 & & \\
\hline 484 & $08 / 11 / 13$ & ML & $\mathrm{R}$ & $\mathrm{H} \& \mathrm{~L}$ & $\mathrm{~F}$ & 790 & 7 & 5755 & 100.4 & 99.3 & 1 & 4 \\
\hline 485 & $08 / 11 / 13$ & ML & $\mathrm{R}$ & $\mathrm{H} \& \mathrm{~L}$ & M & 743 & 8 & 4139 & 178.8 & 26.3 & 1 & \\
\hline 486 & $08 / 11 / 13$ & $\mathrm{ML}$ & & $\mathrm{H} \& \mathrm{~L}$ & $\mathrm{~F}$ & 855 & 7 & 6747 & & & 1 & \\
\hline 487 & $08 / 12 / 13$ & HMB & $\mathrm{R}$ & $\mathrm{H} \& \mathrm{~L}$ & $\mathrm{~F}$ & 801 & 9 & & 369.9 & & 1 & \\
\hline 488 & $08 / 13 / 13$ & $\mathrm{ML}$ & $\mathrm{R}$ & $H \& L$ & $\mathrm{~F}$ & 820 & & 6492 & 341.4 & 134.2 & 1 & 3 \\
\hline
\end{tabular}




\begin{tabular}{|c|c|c|c|c|c|c|c|c|c|c|c|c|}
\hline No. & Date & Site & Fishery & $\begin{array}{l}\text { Gear } \\
\text { Type }\end{array}$ & Sex & $\begin{array}{l}\text { Length } \\
(\mathrm{mm})^{1}\end{array}$ & $\begin{array}{l}\text { Age } \\
(\mathrm{yr})\end{array}$ & $\begin{array}{c}\text { Body } \\
\text { Mass (g) }\end{array}$ & $\begin{array}{c}\text { Gonad } \\
\text { Mass (g) }\end{array}$ & $\begin{array}{c}\text { Liver } \\
\text { Mass (g) }\end{array}$ & $\begin{array}{c}\text { Macro } \\
\text { Mat }\end{array}$ & $\begin{array}{c}\text { Micro } \\
\text { Mat }\end{array}$ \\
\hline 489 & $08 / 13 / 13$ & ML & $\mathrm{R}$ & H\&L & $\mathrm{F}$ & 774 & 8 & 5954 & 229.7 & 107.5 & 1 & 4 \\
\hline 490 & $08 / 13 / 13$ & ML & $\mathrm{R}$ & SP & $\mathrm{F}$ & 871 & 8 & 7711 & 277.0 & 98.1 & 1 & 4 \\
\hline 491 & $08 / 13 / 13$ & $M L$ & $\mathrm{R}$ & SP & $\mathrm{F}$ & 953 & 9 & & 287.3 & 129.5 & 1 & \\
\hline 492 & $08 / 13 / 13$ & $M L$ & $\mathrm{R}$ & SP & $\mathrm{F}$ & 880 & 7 & & 276.5 & 194.4 & 1 & 3 \\
\hline 493 & $08 / 13 / 13$ & ML & $\mathrm{R}$ & $H \& L$ & M & 695 & 8 & 3912 & 91.1 & 25.1 & & \\
\hline 494 & 08/13/13 & $\mathrm{ML}$ & $\mathrm{R}$ & $H \& L$ & M & 718 & 9 & 3884 & 102.6 & 30.4 & & \\
\hline 495 & $08 / 13 / 13$ & ML & $\mathrm{R}$ & $H \& L$ & $\mathrm{~F}$ & 818 & 8 & 6889 & 484.2 & 134.5 & 1 & 4 \\
\hline 496 & $08 / 13 / 13$ & SC & $\mathrm{R}$ & $H \& L$ & M & 450 & 4 & & 17.7 & 5.4 & 1 & \\
\hline 497 & $08 / 14 / 13$ & SC & $\mathrm{R}$ & $H \& L$ & $\mathrm{~F}$ & 641 & 5 & & & & 1 & \\
\hline 498 & $08 / 14 / 13$ & SC & C & $H \& L$ & $\mathrm{~F}$ & 668 & & & & & 1 & \\
\hline 499 & $08 / 14 / 13$ & SC & C & $H \& L$ & $\mathrm{~F}$ & 759 & & & & & 1 & \\
\hline 500 & $08 / 14 / 13$ & SC & C & $H \& L$ & $\mathrm{~F}$ & 768 & & & & & 1 & \\
\hline 501 & 08/14/13 & SC & C & $H \& L$ & $\mathrm{~F}$ & 794 & & & & & 1 & \\
\hline 502 & $08 / 14 / 13$ & SC & C & $H \& L$ & $\mathrm{~F}$ & 795 & & & & & 1 & \\
\hline 503 & $08 / 14 / 13$ & SC & C & $H \& L$ & $\mathrm{~F}$ & 811 & & & & & 1 & \\
\hline 504 & 08/14/13 & SC & C & $H \& L$ & $\mathrm{~F}$ & 815 & & & & & 1 & \\
\hline 505 & $08 / 14 / 13$ & SC & C & $H \& L$ & $\mathrm{~F}$ & 828 & & & & & 1 & \\
\hline 506 & $08 / 14 / 13$ & SC & C & $H \& L$ & $\mathrm{~F}$ & 835 & & & & & 1 & \\
\hline 507 & $08 / 14 / 13$ & SC & C & $H \& L$ & $\mathrm{~F}$ & 836 & & & & & 1 & \\
\hline 508 & 08/14/13 & SC & C & $\mathrm{H} \& \mathrm{~L}$ & $\mathrm{~F}$ & 846 & & & & & 1 & \\
\hline 509 & $08 / 14 / 13$ & SC & C & $\mathrm{H} \& \mathrm{~L}$ & $\mathrm{~F}$ & 871 & & & & & 1 & \\
\hline 510 & 08/14/13 & SC & C & $H \& L$ & $\mathrm{~F}$ & 914 & & & & & 1 & \\
\hline 511 & $08 / 14 / 13$ & SC & C & $H \& L$ & $\mathrm{~F}$ & 944 & & & & & 1 & \\
\hline 512 & $08 / 14 / 13$ & SC & C & H\&L & M & 662 & & & & & 1 & \\
\hline 513 & $08 / 14 / 13$ & SC & C & $H \& L$ & M & 665 & & & & & 1 & \\
\hline 514 & $08 / 14 / 13$ & SC & C & $H \& L$ & M & 707 & & & & & 1 & \\
\hline
\end{tabular}




\begin{tabular}{|c|c|c|c|c|c|c|c|c|c|c|c|c|}
\hline No. & Date & Site & Fishery & $\begin{array}{l}\text { Gear } \\
\text { Type }\end{array}$ & Sex & $\begin{array}{l}\text { Length } \\
(\mathrm{mm})^{1}\end{array}$ & $\begin{array}{l}\text { Age } \\
(\mathrm{yr})\end{array}$ & $\begin{array}{c}\text { Body } \\
\text { Mass (g) }\end{array}$ & $\begin{array}{c}\text { Gonad } \\
\text { Mass (g) }\end{array}$ & $\begin{array}{c}\text { Liver } \\
\text { Mass (g) }\end{array}$ & $\begin{array}{c}\text { Macro } \\
\text { Mat }\end{array}$ & $\begin{array}{l}\text { Micro } \\
\text { Mat }\end{array}$ \\
\hline 515 & $08 / 14 / 13$ & SC & C & $H \& L$ & $\mathrm{~F}$ & 856 & 7 & 8023 & & 149.4 & 1 & \\
\hline 516 & $08 / 14 / 13$ & SC & C & $H \& L$ & M & 623 & 9 & 2807 & 68.7 & 17.6 & 1 & \\
\hline 517 & $08 / 14 / 13$ & SC & $\mathrm{R}$ & $H \& L$ & M & 737 & 9 & & 193.2 & 26.8 & 1 & \\
\hline 518 & $08 / 14 / 13$ & SC & $\mathrm{R}$ & $H \& L$ & $\mathrm{~F}$ & 908 & 8 & & & 103.1 & 1 & \\
\hline 519 & $08 / 14 / 13$ & SC & C & $H \& L$ & $\mathrm{~F}$ & 842 & 8 & 7286 & 222.0 & 131.0 & 1 & 3 \\
\hline 520 & $08 / 14 / 13$ & SC & C & $\mathrm{H} \& \mathrm{~L}$ & M & 574 & 7 & 2466 & 47.1 & 20.4 & 1 & \\
\hline 521 & $08 / 14 / 13$ & SC & $\mathrm{R}$ & $H \& L$ & $\mathrm{~F}$ & 982 & & & & 146.3 & 1 & \\
\hline 522 & $08 / 14 / 13$ & SC & $\mathrm{R}$ & $H \& L$ & M & 618 & 7 & & 96.1 & 18.4 & 1 & \\
\hline 523 & $08 / 14 / 13$ & SC & $\mathrm{R}$ & $H \& L$ & M & 699 & 8 & & 87.8 & 32.2 & 1 & \\
\hline 524 & $08 / 14 / 13$ & SC & $\mathrm{R}$ & $H \& L$ & $\mathrm{~F}$ & 830 & 7 & & 267.0 & 117.1 & 1 & \\
\hline 525 & $08 / 15 / 13$ & ML & $\mathrm{R}$ & $H \& L$ & M & 797 & 8 & 5840 & 222.8 & 49.3 & 1 & \\
\hline 526 & $08 / 15 / 13$ & ML & $\mathrm{R}$ & $H \& L$ & $\mathrm{~F}$ & 979 & 14 & 11085 & 434.2 & 187.7 & 1 & 3 \\
\hline 527 & $08 / 15 / 13$ & ML & $\mathrm{R}$ & $H \& L$ & $\mathrm{~F}$ & 931 & 9 & & & 185.2 & 1 & \\
\hline 528 & $08 / 15 / 13$ & ML & $\mathrm{R}$ & $H \& L$ & $\mathrm{~F}$ & 799 & 9 & & & & 1 & \\
\hline 529 & $08 / 15 / 13$ & ML & $\mathrm{R}$ & $\mathrm{H} \& \mathrm{~L}$ & M & 745 & 9 & & 129.2 & 37.0 & 1 & \\
\hline 530 & $08 / 15 / 13$ & MT & $\mathrm{R}$ & $\mathrm{H} \& \mathrm{~L}$ & $\mathrm{~F}$ & & & 4281 & & 77.0 & 1 & \\
\hline 531 & $08 / 15 / 13$ & ML & $\mathrm{R}$ & $H \& L$ & $\mathrm{~F}$ & 844 & 8 & 7456 & & 116.0 & 1 & 3 \\
\hline 532 & $08 / 15 / 13$ & ML & $\mathrm{R}$ & $H \& L$ & $\mathrm{~F}$ & 846 & 6 & & & 105.5 & 1 & \\
\hline 533 & $08 / 16 / 13$ & MT & C & $H \& L$ & $\mathrm{~F}$ & & & 5358 & & & 1 & \\
\hline 534 & $08 / 16 / 13$ & MT & C & $\mathrm{H} \& \mathrm{~L}$ & $\mathrm{~F}$ & & & 9412 & & & 1 & \\
\hline 535 & $08 / 16 / 13$ & MT & C & $H \& L$ & $\mathrm{~F}$ & & & 9554 & & & 1 & \\
\hline 536 & 08/16/13 & ML & C & $\mathrm{H} \& \mathrm{~L}$ & M & 695 & 7 & & 208.1 & 29.2 & 1 & \\
\hline 537 & 08/16/13 & ML & C & $\mathrm{H} \& \mathrm{~L}$ & $\mathrm{~F}$ & 928 & 7 & & & 174.6 & 1 & \\
\hline 538 & $08 / 16 / 13$ & ML & $\mathrm{R}$ & $\mathrm{H} \& \mathrm{~L}$ & M & 804 & 8 & & 128.4 & 69.2 & 1 & \\
\hline 539 & 08/16/13 & ML & C & $\mathrm{H} \& \mathrm{~L}$ & M & 575 & 7 & & 128.7 & 12.1 & 1 & \\
\hline 540 & $08 / 17 / 13$ & $M L$ & & $H \& L$ & $\mathrm{~F}$ & & & 5954 & & & & \\
\hline
\end{tabular}




\begin{tabular}{|c|c|c|c|c|c|c|c|c|c|c|c|c|}
\hline No. & Date & Site & Fishery & $\begin{array}{l}\text { Gear } \\
\text { Type }\end{array}$ & Sex & $\begin{array}{l}\text { Length } \\
(\mathrm{mm})^{1}\end{array}$ & $\begin{array}{l}\text { Age } \\
(\mathrm{yr})\end{array}$ & $\begin{array}{c}\text { Body } \\
\text { Mass (g) }\end{array}$ & $\begin{array}{c}\text { Gonad } \\
\text { Mass (g) }\end{array}$ & $\begin{array}{c}\text { Liver } \\
\text { Mass (g) }\end{array}$ & $\begin{array}{c}\text { Macro } \\
\text { Mat }\end{array}$ & $\begin{array}{c}\text { Micro } \\
\text { Mat }\end{array}$ \\
\hline 541 & $08 / 17 / 13$ & ML & C & $H \& L$ & $\mathrm{~F}$ & & & 8136 & & & & \\
\hline 542 & $08 / 17 / 13$ & ML & C & $H \& L$ & $\mathrm{~F}$ & & & 11283 & & & 1 & \\
\hline 543 & $08 / 17 / 13$ & $M L$ & & $H \& L$ & $\mathrm{~F}$ & & & 15819 & & & & \\
\hline 544 & $08 / 17 / 13$ & ML & C & $H \& L$ & M & & & 3430 & & & 1 & \\
\hline 545 & $08 / 17 / 13$ & $M L$ & $\mathrm{R}$ & $H \& L$ & M & & & 4139 & & & 1 & \\
\hline 546 & $08 / 17 / 13$ & $\mathrm{HMB}$ & $\mathrm{R}$ & $H \& L$ & $\mathrm{~F}$ & 862 & 7 & & 423.6 & & 1 & \\
\hline 547 & $08 / 17 / 13$ & $\mathrm{ML}$ & $\mathrm{R}$ & $H \& L$ & $\mathrm{~F}$ & 1120 & 14 & & 550.7 & 225.2 & 1 & 3 \\
\hline 548 & $08 / 17 / 13$ & SC & $\mathrm{R}$ & $H \& L$ & $\mathrm{~F}$ & 880 & 7 & & 481.7 & 115.1 & 1 & 4 \\
\hline 549 & $08 / 17 / 13$ & ML & C & $H \& L$ & M & & 7 & 3544 & 94.6 & 29.7 & 1 & \\
\hline 550 & $08 / 18 / 13$ & SC & $\mathrm{R}$ & $H \& L$ & $\mathrm{~F}$ & & & 9163 & & & & \\
\hline 551 & $08 / 18 / 13$ & PSL & $\mathrm{R}$ & $H \& L$ & $\mathrm{~F}$ & 862 & 7 & 7031 & 138.2 & 62.4 & 1 & 3 \\
\hline 552 & $08 / 18 / 13$ & $\mathrm{ML}$ & & $H \& L$ & M & 815 & 10 & & 380.3 & 50.5 & 1 & \\
\hline 553 & $08 / 18 / 13$ & SC & $\mathrm{R}$ & $H \& L$ & $\mathrm{~F}$ & 857 & 7 & 7853 & & 164.9 & 0 & \\
\hline 554 & $08 / 18 / 13$ & ML & $\mathrm{R}$ & SP & $\mathrm{F}$ & 970 & & & 417.7 & 158.3 & 1 & 3 \\
\hline 555 & 08/18/13 & $M L$ & $\mathrm{R}$ & SP & $\mathrm{F}$ & 823 & 8 & & & 113.3 & 1 & \\
\hline 556 & $08 / 18 / 13$ & ML & $\mathrm{R}$ & SP & $\mathrm{F}$ & 1039 & 9 & & 714.2 & & 1 & 3 \\
\hline 557 & $08 / 18 / 13$ & $M L$ & $\mathrm{R}$ & SP & M & 632 & 8 & & 138.0 & 31.9 & 1 & \\
\hline 558 & $08 / 18 / 13$ & ML & $\mathrm{R}$ & SP & $\mathrm{F}$ & & & & 373.2 & & 1 & \\
\hline 559 & $08 / 18 / 13$ & ML & $\mathrm{R}$ & SP & M & 837 & 8 & & 192.9 & 51.1 & 1 & \\
\hline 560 & $08 / 18 / 13$ & ML & $\mathrm{R}$ & SP & $\mathrm{F}$ & 970 & 7 & & 275.5 & 166.7 & 1 & 3 \\
\hline 561 & $08 / 18 / 13$ & ML & $\mathrm{R}$ & SP & $\mathrm{F}$ & 922 & 10 & & 295.2 & 135.1 & 1 & 3 \\
\hline 562 & $08 / 18 / 13$ & ML & $\mathrm{R}$ & SP & M & 745 & 8 & & 118.5 & 40.0 & 1 & \\
\hline 563 & 08/18/13 & ML & $\mathrm{R}$ & SP & M & 791 & 8 & & 190.3 & 65.8 & 1 & \\
\hline 564 & $08 / 18 / 13$ & ML & $\mathrm{R}$ & SP & $\mathrm{F}$ & 907 & 9 & & & & 1 & \\
\hline 565 & $08 / 18 / 13$ & $M L$ & $\mathrm{R}$ & SP & M & 815 & 8 & & & 52.4 & 1 & \\
\hline 566 & $08 / 18 / 13$ & ML & $\mathrm{R}$ & SP & M & 714 & 9 & & & & 1 & \\
\hline
\end{tabular}




\begin{tabular}{|c|c|c|c|c|c|c|c|c|c|c|c|c|}
\hline No. & Date & Site & Fishery & $\begin{array}{l}\text { Gear } \\
\text { Type }\end{array}$ & Sex & $\begin{array}{l}\text { Length } \\
(\mathrm{mm})^{1}\end{array}$ & $\begin{array}{l}\text { Age } \\
(\mathrm{yr})\end{array}$ & $\begin{array}{c}\text { Body } \\
\text { Mass (g) }\end{array}$ & $\begin{array}{c}\text { Gonad } \\
\text { Mass (g) }\end{array}$ & $\begin{array}{c}\text { Liver } \\
\text { Mass (g) }\end{array}$ & $\begin{array}{c}\text { Macro } \\
\text { Mat }\end{array}$ & $\begin{array}{c}\text { Micro } \\
\text { Mat }\end{array}$ \\
\hline 567 & $08 / 18 / 13$ & ML & $\mathrm{R}$ & $\mathrm{SP}$ & M & 738 & 8 & & & 49.5 & & \\
\hline 568 & $08 / 18 / 13$ & ML & $\mathrm{R}$ & SP & M & 704 & 8 & & & & 1 & \\
\hline 569 & $08 / 18 / 13$ & $M L$ & $\mathrm{R}$ & SP & M & 769 & 9 & & 123.7 & 47.1 & 1 & \\
\hline 570 & $08 / 18 / 13$ & ML & $\mathrm{R}$ & SP & $\mathrm{F}$ & 884 & 8 & & 447.7 & & 1 & 4 \\
\hline 571 & $08 / 18 / 13$ & ML & $\mathrm{R}$ & SP & $\mathrm{F}$ & 747 & 5 & & & 69.7 & 1 & \\
\hline 572 & $08 / 18 / 13$ & SC & $\mathrm{R}$ & $H \& L$ & $\mathrm{~F}$ & 831 & 9 & 6889 & & 125.8 & 0 & \\
\hline 573 & $08 / 18 / 13$ & SC & $\mathrm{R}$ & $\mathrm{H} \& \mathrm{~L}$ & M & 619 & 8 & 2381 & 41.3 & 20.0 & 1 & \\
\hline 574 & $08 / 18 / 13$ & SC & $\mathrm{R}$ & $H \& L$ & $\mathrm{~F}$ & 843 & 7 & 6237 & 174.3 & 96.3 & 1 & 3 \\
\hline 575 & 08/18/13 & SC & $\mathrm{R}$ & $H \& L$ & $\mathrm{~F}$ & 855 & 7 & & & & 0 & \\
\hline 576 & $08 / 20 / 13$ & SC & $\mathrm{R}$ & $H \& L$ & $\mathrm{~F}$ & 875 & 8 & & 287.4 & 103.0 & 1 & 3 \\
\hline 577 & $08 / 24 / 13$ & MB & & $H \& L$ & M & 960 & 12 & 9200 & 117.4 & 104.8 & 1 & \\
\hline 578 & $08 / 24 / 13$ & PSL & $\mathrm{R}$ & $H \& L$ & $\mathrm{~F}$ & 595 & 5 & 2268 & 27.8 & 24.6 & 0 & 1 or 6 \\
\hline 579 & $08 / 24 / 13$ & SC & $\mathrm{R}$ & $H \& L$ & $\mathrm{~F}$ & 781 & & 5557 & & & & \\
\hline 580 & $08 / 24 / 13$ & $\mathrm{ML}$ & $\mathrm{R}$ & SP & $\mathrm{F}$ & & & 7144 & & & & \\
\hline 581 & $08 / 24 / 13$ & PSL & & $H \& L$ & $\mathrm{~F}$ & & & 7286 & & & & \\
\hline 582 & $08 / 24 / 13$ & $\mathrm{ML}$ & $\mathrm{R}$ & SP & $\mathrm{F}$ & & & 7598 & & & & \\
\hline 583 & $08 / 24 / 13$ & $M L$ & $\mathrm{R}$ & SP & $\mathrm{F}$ & & & 8533 & & & & \\
\hline 584 & $08 / 24 / 13$ & ML & $\mathrm{R}$ & SP & M & & & 7201 & & & 1 & \\
\hline 585 & $08 / 24 / 13$ & ML & $\mathrm{R}$ & SP & M & & & 4139 & & & 1 & \\
\hline 586 & $08 / 24 / 13$ & ML & $\mathrm{R}$ & $\mathrm{H} \& \mathrm{~L}$ & $\mathrm{~F}$ & 893 & 8 & 8193 & 322.1 & 113.6 & 1 & 3 \\
\hline 587 & $08 / 24 / 13$ & SC & $\mathrm{R}$ & $H \& L$ & $\mathrm{~F}$ & 907 & 8 & & 551.8 & 139.5 & 1 & 4 \\
\hline 588 & $08 / 24 / 13$ & SC & $\mathrm{R}$ & $\mathrm{H} \& \mathrm{~L}$ & M & 724 & 8 & & 79.1 & 37.0 & 1 & \\
\hline 589 & $08 / 25 / 13$ & MB & C & $\mathrm{H} \& \mathrm{~L}$ & $\mathrm{~F}$ & 850 & 7 & 7399 & 201.3 & 138.2 & 1 & 3 \\
\hline 590 & $08 / 25 / 13$ & SC & $\mathrm{R}$ & $H \& L$ & M & 661 & 7 & & 78.0 & 33.8 & 1 & \\
\hline 591 & $08 / 25 / 13$ & MB & & $\mathrm{H} \& \mathrm{~L}$ & $\mathrm{~F}$ & 715 & 4 & 4111 & 32.3 & 68.5 & 0 & 2 \\
\hline 592 & $08 / 25 / 13$ & $\mathrm{ML}$ & C & $\mathrm{H} \& \mathrm{~L}$ & $\mathrm{~F}$ & & & 9299 & & & & \\
\hline
\end{tabular}




\begin{tabular}{|c|c|c|c|c|c|c|c|c|c|c|c|c|}
\hline No. & Date & Site & Fishery & $\begin{array}{l}\text { Gear } \\
\text { Type }\end{array}$ & Sex & $\begin{array}{l}\text { Length } \\
(\mathrm{mm})^{1}\end{array}$ & $\begin{array}{l}\text { Age } \\
\text { (yr) }\end{array}$ & $\begin{array}{c}\text { Body } \\
\text { Mass (g) }\end{array}$ & $\begin{array}{c}\text { Gonad } \\
\text { Mass (g) }\end{array}$ & $\begin{array}{c}\text { Liver } \\
\text { Mass (g) }\end{array}$ & $\begin{array}{c}\text { Macro } \\
\text { Mat }\end{array}$ & $\begin{array}{c}\text { Micro } \\
\text { Mat }\end{array}$ \\
\hline 593 & $08 / 25 / 13$ & ML & C & $\mathrm{H} \& \mathrm{~L}$ & $\mathrm{~F}$ & & & 11425 & & & & \\
\hline 594 & $08 / 25 / 13$ & ML & & $H \& L$ & M & & & 4366 & & & 1 & \\
\hline 595 & $08 / 25 / 13$ & MB & C & $H \& L$ & $\mathrm{~F}$ & 820 & 7 & 7314 & 401.4 & 142.5 & 1 & 4 \\
\hline 596 & $08 / 25 / 13$ & SC & $\mathrm{R}$ & $H \& L$ & $\mathrm{~F}$ & 895 & 8 & & & 124.1 & 1 & \\
\hline 597 & $08 / 25 / 13$ & MT & C & $H \& L$ & $\mathrm{~F}$ & 872 & 9 & 7881 & & & 1 & \\
\hline 598 & $08 / 25 / 13$ & MT & C & $H \& L$ & M & 784 & 8 & 5216 & 110.1 & 45.9 & 1 & \\
\hline 599 & $08 / 26 / 13$ & SC & $\mathrm{R}$ & $H \& L$ & $\mathrm{~F}$ & 818 & 8 & & 166.4 & 44.6 & 1 & 4 \\
\hline 600 & $08 / 26 / 13$ & SC & $\mathrm{R}$ & $H \& L$ & $\mathrm{~F}$ & 907 & 10 & & 389.9 & 134.0 & 1 & 4 \\
\hline 601 & $08 / 26 / 13$ & $M L$ & & $H \& L$ & $\mathrm{~F}$ & & & 5103 & & & & \\
\hline 602 & $08 / 26 / 13$ & ML & C & $H \& L$ & $\mathrm{~F}$ & & & 5500 & & & & \\
\hline 603 & $08 / 26 / 13$ & $M L$ & C & $H \& L$ & $\mathrm{~F}$ & & & 9696 & & & & \\
\hline 604 & $08 / 26 / 13$ & ML & $\mathrm{R}$ & SP & $\mathrm{F}$ & & & 10575 & & & & \\
\hline 605 & $08 / 26 / 13$ & $M L$ & $\mathrm{R}$ & SP & $\mathrm{F}$ & & & 11992 & & & & \\
\hline 606 & $08 / 26 / 13$ & ML & C & $H \& L$ & $\mathrm{~F}$ & & & & & & & \\
\hline 607 & 08/26/13 & $M L$ & C & $H \& L$ & $\mathrm{~F}$ & & & & & & & \\
\hline 608 & $08 / 26 / 13$ & ML & C & $\mathrm{H} \& \mathrm{~L}$ & $\mathrm{~F}$ & & & & & & & \\
\hline 609 & $08 / 26 / 13$ & ML & C & $H \& L$ & $\mathrm{~F}$ & & & & & & & \\
\hline 610 & $08 / 26 / 13$ & ML & C & $H \& L$ & $\mathrm{~F}$ & & & & & & & \\
\hline 611 & $08 / 26 / 13$ & ML & C & $H \& L$ & $\mathrm{~F}$ & & & & & & & \\
\hline 612 & 08/26/13 & $M L$ & & $H \& L$ & M & & & 5075 & & & 1 & \\
\hline 613 & $08 / 26 / 13$ & ML & $\mathrm{R}$ & SP & M & & & 5245 & & & 1 & \\
\hline 614 & 08/26/13 & $M L$ & C & $H \& L$ & M & & & 7314 & & & 1 & \\
\hline 615 & $08 / 26 / 13$ & ML & C & $H \& L$ & M & & & & & & 1 & \\
\hline 616 & $08 / 26 / 13$ & ML & C & $H \& L$ & M & & & & & & 1 & \\
\hline 617 & $08 / 26 / 13$ & ML & C & $H \& L$ & M & & & & & & 1 & \\
\hline 618 & $08 / 26 / 13$ & $M L$ & $\mathrm{R}$ & $\mathrm{SP}$ & $\mathrm{F}$ & 914 & 8 & 8590 & 316.3 & 132.5 & 1 & 4 \\
\hline
\end{tabular}




\begin{tabular}{|c|c|c|c|c|c|c|c|c|c|c|c|c|}
\hline No. & Date & Site & Fishery & $\begin{array}{l}\text { Gear } \\
\text { Type }\end{array}$ & Sex & $\begin{array}{l}\text { Length } \\
(\mathrm{mm})^{1}\end{array}$ & $\begin{array}{l}\text { Age } \\
(\mathrm{yr})\end{array}$ & $\begin{array}{c}\text { Body } \\
\text { Mass (g) }\end{array}$ & $\begin{array}{c}\text { Gonad } \\
\text { Mass (g) }\end{array}$ & $\begin{array}{c}\text { Liver } \\
\text { Mass (g) }\end{array}$ & $\begin{array}{c}\text { Macro } \\
\text { Mat }\end{array}$ & $\begin{array}{c}\text { Micro } \\
\text { Mat }\end{array}$ \\
\hline 619 & $08 / 26 / 13$ & ML & $\mathrm{R}$ & $\mathrm{SP}$ & M & 785 & 9 & 5415 & 117.1 & 44.6 & 1 & \\
\hline 620 & $08 / 26 / 13$ & ML & $\mathrm{R}$ & SP & $\mathrm{F}$ & 829 & 8 & 6691 & 200.6 & 96.9 & 1 & 4 \\
\hline 621 & $08 / 26 / 13$ & $M L$ & $\mathrm{R}$ & SP & $\mathrm{F}$ & 909 & 9 & 8392 & 327.8 & 167.0 & 1 & 4 \\
\hline 622 & 08/26/13 & $M L$ & $\mathrm{R}$ & SP & $\mathrm{F}$ & 1001 & 7 & 11935 & 329.9 & 253.3 & 1 & 4 \\
\hline 623 & $08 / 28 / 13$ & ML & $\mathrm{R}$ & $H \& L$ & M & 736 & 8 & 4564 & 124.1 & 35.2 & 1 & \\
\hline 624 & $08 / 28 / 13$ & ML & C & $H \& L$ & $\mathrm{~F}$ & & & 4649 & & & & \\
\hline 625 & $08 / 28 / 13$ & ML & $\mathrm{R}$ & $H \& L$ & $\mathrm{~F}$ & & & 5812 & & & & \\
\hline 626 & $08 / 28 / 13$ & $M L$ & C & $H \& L$ & $\mathrm{~F}$ & & & 7144 & & & & \\
\hline 627 & $08 / 28 / 13$ & ML & C & $H \& L$ & $\mathrm{~F}$ & & & 7002 & & & & \\
\hline 628 & $08 / 28 / 13$ & ML & C & $H \& L$ & $\mathrm{~F}$ & & & 7740 & & & & \\
\hline 629 & $08 / 28 / 13$ & ML & C & $H \& L$ & $\mathrm{~F}$ & & & 7966 & & & & \\
\hline 630 & $08 / 28 / 13$ & ML & C & $H \& L$ & $\mathrm{~F}$ & & & 8165 & & 123.6 & & \\
\hline 631 & $08 / 28 / 13$ & ML & C & $H \& L$ & $\mathrm{~F}$ & & & 9157 & & & & \\
\hline 632 & $08 / 28 / 13$ & ML & $\mathrm{R}$ & $H \& L$ & $\mathrm{~F}$ & & & 10433 & & & & \\
\hline 633 & 08/28/13 & $M L$ & C & $H \& L$ & $\mathrm{~F}$ & & & 10716 & & & & \\
\hline 634 & $08 / 28 / 13$ & ML & C & $\mathrm{H} \& \mathrm{~L}$ & $\mathrm{~F}$ & & & 11935 & & & & \\
\hline 635 & $08 / 28 / 13$ & ML & $\mathrm{R}$ & $H \& L$ & $\mathrm{~F}$ & & & 16074 & & & 1 & \\
\hline 636 & $08 / 28 / 13$ & ML & C & $H \& L$ & M & & & 5472 & & & 1 & \\
\hline 637 & $08 / 28 / 13$ & ML & $\mathrm{R}$ & $H \& L$ & M & & & 10008 & & & 1 & \\
\hline 638 & $08 / 28 / 13$ & SC & $\mathrm{R}$ & $H \& L$ & $\mathrm{~F}$ & 925 & 10 & & 481.8 & 184.5 & 1 & 3 \\
\hline 639 & $08 / 28 / 13$ & SC & $\mathrm{R}$ & $H \& L$ & $\mathrm{~F}$ & 883 & 8 & & 149.0 & 104.7 & 0 & 5 \\
\hline 640 & 08/28/13 & ML & C & $H \& L$ & $\mathrm{~F}$ & 1046 & 19 & 15026 & & & 1 & \\
\hline 641 & $08 / 28 / 13$ & ML & C & $\mathrm{H} \& \mathrm{~L}$ & $\mathrm{~F}$ & 1026 & 10 & 12843 & 352.7 & 316.2 & 0 & 5 \\
\hline 642 & $08 / 28 / 13$ & ML & C & $\mathrm{H} \& \mathrm{~L}$ & M & 810 & 9 & 6407 & 137.1 & 46.6 & 1 & \\
\hline 643 & $08 / 28 / 13$ & ML & C & $H \& L$ & M & 626 & 7 & 2977 & 101.7 & 29.9 & 1 & \\
\hline 644 & $08 / 28 / 13$ & $M L$ & C & $\mathrm{H} \& \mathrm{~L}$ & $\mathrm{~F}$ & 888 & 7 & 8902 & 193.6 & 141.7 & 1 & 3 \\
\hline
\end{tabular}




\begin{tabular}{|c|c|c|c|c|c|c|c|c|c|c|c|c|}
\hline No. & Date & Site & Fishery & $\begin{array}{l}\text { Gear } \\
\text { Type }\end{array}$ & Sex & $\begin{array}{l}\text { Length } \\
(\mathrm{mm})^{1}\end{array}$ & $\begin{array}{l}\text { Age } \\
(\mathrm{yr})\end{array}$ & $\begin{array}{c}\text { Body } \\
\text { Mass (g) }\end{array}$ & $\begin{array}{c}\text { Gonad } \\
\text { Mass (g) }\end{array}$ & $\begin{array}{c}\text { Liver } \\
\text { Mass (g) }\end{array}$ & $\begin{array}{c}\text { Macro } \\
\text { Mat }\end{array}$ & $\begin{array}{c}\text { Micro } \\
\text { Mat }\end{array}$ \\
\hline 645 & $08 / 28 / 13$ & ML & C & $H \& L$ & M & 630 & 6 & 2977 & 34.7 & 33.0 & 1 & \\
\hline 646 & $08 / 28 / 13$ & ML & C & $H \& L$ & $\mathrm{~F}$ & 1064 & 13 & 14005 & 424.5 & 273.8 & 1 & 3 \\
\hline 647 & $08 / 29 / 13$ & SC & $\mathrm{R}$ & $H \& L$ & M & 629 & 8 & & 78.6 & 21.7 & 1 & \\
\hline 648 & 08/30/13 & SC & $\mathrm{R}$ & $H \& L$ & $\mathrm{~F}$ & 982 & 9 & & 457.9 & 148.2 & 1 & 4 \\
\hline 649 & $08 / 30 / 13$ & SC & $\mathrm{R}$ & $H \& L$ & $\mathrm{~F}$ & 777 & 8 & & 84.1 & 50.0 & 1 & 3 \\
\hline 650 & $08 / 30 / 13$ & SC & $\mathrm{R}$ & $H \& L$ & $\mathrm{~F}$ & 874 & 9 & & 299.5 & 133.6 & 1 & 4 \\
\hline 651 & $08 / 30 / 13$ & SC & $\mathrm{R}$ & $H \& L$ & $\mathrm{~F}$ & 866 & 9 & & 204.7 & 85.3 & 1 & 4 \\
\hline 652 & $08 / 30 / 13$ & SC & $\mathrm{R}$ & $H \& L$ & $\mathrm{~F}$ & 895 & 7 & & 232.1 & 99.5 & 1 & 3 \\
\hline 653 & $08 / 31 / 13$ & ML & C & $H \& L$ & $\mathrm{~F}$ & & & 7144 & & & & \\
\hline 654 & $08 / 31 / 13$ & ML & C & $H \& L$ & $\mathrm{~F}$ & & & 7569 & & & 1 & \\
\hline 655 & $08 / 31 / 13$ & ML & & $H \& L$ & $\mathrm{~F}$ & & & 8051 & & & & \\
\hline 656 & $08 / 31 / 13$ & ML & & $H \& L$ & $\mathrm{~F}$ & & & 15281 & & & & \\
\hline 657 & $08 / 31 / 13$ & $M L$ & C & $H \& L$ & M & & & 2495 & & & 1 & \\
\hline 658 & $08 / 31 / 13$ & PSL & $\mathrm{R}$ & $H \& L$ & M & 759 & 7 & 5131 & 25.6 & 53.1 & 1 & \\
\hline 659 & $08 / 31 / 13$ & PSL & $\mathrm{R}$ & $H \& L$ & $\mathrm{~F}$ & 835 & 7 & 7088 & 62.6 & 91.7 & 0 & 2 \\
\hline 660 & $08 / 31 / 13$ & SC & $\mathrm{R}$ & $\mathrm{H} \& \mathrm{~L}$ & M & 555 & 8 & 1814 & 31.3 & 18.3 & 0 & \\
\hline 661 & $09 / 01 / 13$ & $M L$ & $\mathrm{R}$ & $H \& L$ & M & 714 & 14 & 4820 & 233.7 & 51.3 & 1 & \\
\hline 662 & $09 / 01 / 13$ & SC & & $H \& L$ & $\mathrm{~F}$ & 896 & 8 & 9327 & 368.8 & 164.2 & 1 & 3 \\
\hline 663 & $09 / 01 / 13$ & ML & $\mathrm{R}$ & $H \& L$ & $\mathrm{~F}$ & 863 & 8 & & 241.0 & 143.5 & 1 & 3 \\
\hline 664 & $09 / 02 / 13$ & MB & & $H \& L$ & $\mathrm{~F}$ & 725 & 7 & & & & 1 & \\
\hline 665 & $09 / 02 / 13$ & MB & & $H \& L$ & $\mathrm{~F}$ & 790 & 8 & & & & 0 & 2 \\
\hline 666 & $09 / 02 / 13$ & SC & $\mathrm{R}$ & $\mathrm{H} \& \mathrm{~L}$ & $\mathrm{~F}$ & 911 & 9 & & 420.9 & 130.7 & 1 & 3 \\
\hline 667 & $09 / 02 / 13$ & ML & $\mathrm{R}$ & $\mathrm{H} \& \mathrm{~L}$ & $\mathrm{~F}$ & 890 & 9 & 8845 & 331.2 & 133.1 & 1 & 3 \\
\hline 668 & $09 / 02 / 13$ & SC & C & $\mathrm{H} \& \mathrm{~L}$ & $\mathrm{~F}$ & 933 & 8 & 8165 & 284.5 & 116.4 & 1 & 3 \\
\hline 669 & $09 / 04 / 13$ & SC & $\mathrm{R}$ & $\mathrm{H} \& \mathrm{~L}$ & M & 715 & 9 & & 33.2 & 31.3 & 1 & \\
\hline 670 & $09 / 05 / 13$ & $\mathrm{SC}$ & C & $H \& L$ & M & 577 & 7 & 2466 & 53.2 & 18.1 & 1 & \\
\hline
\end{tabular}




\begin{tabular}{|c|c|c|c|c|c|c|c|c|c|c|c|c|}
\hline No. & Date & Site & Fishery & $\begin{array}{l}\text { Gear } \\
\text { Type }\end{array}$ & Sex & $\begin{array}{l}\text { Length } \\
(\mathrm{mm})^{1}\end{array}$ & $\begin{array}{l}\text { Age } \\
(\mathrm{yr})\end{array}$ & $\begin{array}{c}\text { Body } \\
\text { Mass (g) }\end{array}$ & $\begin{array}{c}\text { Gonad } \\
\text { Mass (g) }\end{array}$ & $\begin{array}{c}\text { Liver } \\
\text { Mass (g) }\end{array}$ & $\begin{array}{c}\text { Macro } \\
\text { Mat }\end{array}$ & $\begin{array}{c}\text { Micro } \\
\text { Mat }\end{array}$ \\
\hline 671 & $09 / 05 / 13$ & SC & C & $H \& L$ & $\mathrm{~F}$ & 700 & & & & & 1 & \\
\hline 672 & $09 / 05 / 13$ & SC & C & $H \& L$ & $\mathrm{~F}$ & 732 & & & & & 1 & \\
\hline 673 & $09 / 05 / 13$ & SC & C & $H \& L$ & $\mathrm{~F}$ & 751 & & & & & 1 & \\
\hline 674 & 09/05/13 & SC & C & $H \& L$ & $\mathrm{~F}$ & 755 & & & & & 1 & \\
\hline 675 & $09 / 05 / 13$ & SC & C & $H \& L$ & $\mathrm{~F}$ & 770 & & & & & 1 & \\
\hline 676 & $09 / 05 / 13$ & SC & C & $\mathrm{H} \& \mathrm{~L}$ & $\mathrm{~F}$ & 779 & & & & & 1 & \\
\hline 677 & $09 / 05 / 13$ & SC & C & $\mathrm{H} \& \mathrm{~L}$ & $\mathrm{~F}$ & 788 & & & & & 1 & \\
\hline 678 & $09 / 05 / 13$ & SC & C & $H \& L$ & $\mathrm{~F}$ & 790 & & & & & 1 & \\
\hline 679 & $09 / 05 / 13$ & SC & C & $H \& L$ & $\mathrm{~F}$ & 793 & & & & & 1 & \\
\hline 680 & $09 / 05 / 13$ & SC & C & $H \& L$ & $\mathrm{~F}$ & 805 & & & & & 1 & \\
\hline 681 & $09 / 05 / 13$ & SC & C & $H \& L$ & $\mathrm{~F}$ & 827 & & & & & 1 & \\
\hline 682 & $09 / 05 / 13$ & SC & C & $H \& L$ & $\mathrm{~F}$ & 831 & & & & & 1 & \\
\hline 683 & $09 / 05 / 13$ & SC & C & $H \& L$ & $\mathrm{~F}$ & 836 & & & & & 1 & \\
\hline 684 & $09 / 05 / 13$ & SC & C & $H \& L$ & $\mathrm{~F}$ & 853 & & & & & 1 & \\
\hline 685 & $09 / 05 / 13$ & SC & C & $H \& L$ & $\mathrm{~F}$ & 873 & & & & & 1 & \\
\hline 686 & $09 / 05 / 13$ & SC & C & $\mathrm{H} \& \mathrm{~L}$ & $\mathrm{~F}$ & 895 & & & & & 1 & \\
\hline 687 & $09 / 05 / 13$ & SC & C & $H \& L$ & $\mathrm{~F}$ & 919 & & & & & 1 & \\
\hline 688 & $09 / 05 / 13$ & SC & C & $\mathrm{H} \& \mathrm{~L}$ & $\mathrm{~F}$ & 930 & & & & & 1 & \\
\hline 689 & $09 / 05 / 13$ & SC & C & $H \& L$ & $\mathrm{~F}$ & 930 & & & & & 1 & \\
\hline 690 & $09 / 05 / 13$ & SC & C & $\mathrm{H} \& \mathrm{~L}$ & $\mathrm{~F}$ & 1015 & & & & & 1 & \\
\hline 691 & $09 / 05 / 13$ & SC & C & $H \& L$ & $\mathrm{~F}$ & 1023 & & & & & 1 & \\
\hline 692 & $09 / 05 / 13$ & SC & C & $\mathrm{H} \& \mathrm{~L}$ & M & 575 & & & & & 1 & \\
\hline 693 & $09 / 05 / 13$ & SC & C & $\mathrm{H} \& \mathrm{~L}$ & M & 758 & & & & & 1 & \\
\hline 694 & $09 / 08 / 13$ & MB & & $\mathrm{H} \& \mathrm{~L}$ & M & 808 & 9 & 6100 & 39.3 & 45.8 & 1 & \\
\hline 695 & $09 / 08 / 13$ & ML & $\mathrm{R}$ & $\mathrm{H} \& \mathrm{~L}$ & M & 829 & 7 & & 67.7 & 50.0 & 1 & \\
\hline 696 & $09 / 15 / 13$ & MB & $\mathrm{R}$ & $H \& L$ & $M$ & 713 & 6 & 4281 & 23.7 & 59.9 & 1 & \\
\hline
\end{tabular}




\begin{tabular}{rcccccccrrrrr}
\hline No. & Date & Site & Fishery & $\begin{array}{c}\text { Gear } \\
\text { Type }\end{array}$ & Sex & $\begin{array}{c}\text { Length } \\
(\mathrm{mm})^{1}\end{array}$ & $\begin{array}{c}\text { Age } \\
(\mathrm{yr})\end{array}$ & $\begin{array}{c}\text { Body } \\
\text { Mass (g) }\end{array}$ & $\begin{array}{c}\text { Gonad } \\
\text { Mass (g) }\end{array}$ & $\begin{array}{c}\text { Liver } \\
\text { Mass (g) }\end{array}$ & $\begin{array}{c}\text { Macro } \\
\text { Mat }\end{array}$ & $\begin{array}{c}\text { Micro } \\
\text { Mat }\end{array}$ \\
\hline 697 & $09 / 19 / 13$ & SC & R & H\&L & M & 635 & 7 & & 42.2 & 27.4 & 1 & \\
698 & $09 / 30 / 13$ & SC & C & H\&L & F & 958 & 8 & 11198 & 162.6 & 155.3 & 0 & 2 \\
699 & $09 / 30 / 13$ & MTB & C & H\&L & F & 757 & 8 & & 73.8 & 66.8 & 0 & 5 \\
700 & $09 / 30 / 13$ & SC & C & H\&L & F & 891 & 8 & 8193 & 122.0 & 125.4 & 0 & 5 \\
701 & $09 / 30 / 13$ & MTB & C & H\&L & F & 788 & 9 & & 125.9 & 71.0 & 0 & 3 \\
702 & $09 / 30 / 13$ & MTB & C & H\&L & F & 891 & 8 & & 125.8 & 142.8 & 0 & 2 \\
703 & $10 / 18 / 13$ & MTB & C & H\&L & F & 868 & 7 & & 77.9 & 74.4 & 0 & 2 \\
704 & $11 / 25 / 13$ & SC & R & H\&L & F & 790 & 8 & 6435 & 184.0 & 87.6 & 1 & 3 \\
\hline
\end{tabular}


APPENDIX II

Fecundity data associated with central California Halibut, 2012 and 2013. 'No.' corresponds to the same fish number in Appendix I. Spawning phase: $\mathrm{EH}=$ early hydration, $\mathrm{LH}=$ late hydration, $\mathrm{AS}=$ active spawning, $\mathrm{ST}=\mathrm{spent}$. $\mathrm{HD}=$

hydrated only egg mass, OW = ovarian wall. Missing values are a result of fish lacking loose hydrated oocytes (i.e., all hydrated oocytes were mixed throughout the ovary and encompassed in 'assorted' densities).

\begin{tabular}{|c|c|c|c|c|c|c|c|c|c|c|}
\hline No. & $\begin{array}{c}\text { Spawning } \\
\text { Phase }\end{array}$ & $\begin{array}{c}\text { Ovary } \\
\text { Mass (g) }\end{array}$ & $\begin{array}{c}\text { 'HD' } \\
\text { Mass (g) }\end{array}$ & $\begin{array}{c}\text { OW } \\
\text { Mass (g) }\end{array}$ & $\begin{array}{c}\text { 'Assorted' } \\
\text { Mass (g) }\end{array}$ & $\begin{array}{c}\text { 'Assorted' } \\
\text { Density } \\
\text { (HD/g) }\end{array}$ & $\begin{array}{c}\text { 'HD' } \\
\text { Density } \\
\text { (HD/g) }\end{array}$ & $\begin{array}{c}\text { 'Assorted' } \\
\text { No. }\end{array}$ & $\begin{array}{l}\text { 'HD' } \\
\text { No. }\end{array}$ & $\begin{array}{c}\text { Batch } \\
\text { Fecundity }\end{array}$ \\
\hline 9 & AS & 192.2 & 11.7 & 26.1 & 154.4 & 79 & 2349 & 12202 & 27480 & 39681 \\
\hline 18 & $\mathrm{EH}$ & 324.6 & & 32.6 & 292.0 & 2225 & & 649760 & & 649760 \\
\hline 27 & AS & 428.5 & & 28.6 & 399.9 & 1379 & & 551595 & & 551595 \\
\hline 31 & $\mathrm{LH}$ & 272.0 & & 24.7 & 247.3 & 949 & & 234621 & & 234621 \\
\hline 36 & $\mathrm{EH}$ & 342.2 & & 34.9 & 307.3 & 304 & & 93394 & & 93394 \\
\hline 40 & LH & 337.2 & & 27.0 & 310.2 & 1671 & & 518403 & & 518403 \\
\hline 77 & $\mathrm{LH}$ & 232.3 & & 17.3 & 215.0 & 1808 & & 388557 & & 388557 \\
\hline 112 & AS & 134.1 & 9.7 & 18.2 & 106.2 & 71 & 3775 & 7576 & 36618 & 44320 \\
\hline 197 & AS & 178.1 & 29.1 & 16.0 & 133.0 & 296 & 4893 & 39323 & 142378 & 181700 \\
\hline 209 & $\mathrm{LH}$ & 362.2 & 13.9 & 26.2 & 322.1 & 1393 & 3071 & 448737 & 42688 & 491426 \\
\hline 226 & AS & 236.8 & 53.3 & 16.3 & 167.2 & 551 & 4551 & 92069 & 242590 & 334659 \\
\hline 264 & AS & 334.0 & & 22.6 & 311.4 & 1437 & & 447353 & & 447353 \\
\hline 266 & $\mathrm{LH}$ & 410.2 & & 42.8 & 367.4 & 588 & & 216009 & & 216009 \\
\hline 270 & LH & 523.2 & 11.2 & 39.6 & 472.4 & 1491 & 2027 & 704340 & 22699 & 727039 \\
\hline 306 & $\mathrm{LH}$ & 442.2 & & 32.5 & 409.7 & 1425 & & 584010 & & 584010 \\
\hline 308 & $\mathrm{LH}$ & 447.1 & & 26.6 & 420.5 & 1719 & & 722700 & & 722700 \\
\hline 325 & AS & 410.8 & 43.1 & 35.2 & 332.5 & 1130 & 3875 & 375700 & 166996 & 542696 \\
\hline 334 & $\mathrm{EH}$ & 239.1 & & 17.5 & 221.6 & 2064 & & 457365 & & 457365 \\
\hline 342 & LH & 451.5 & 14.6 & 26.2 & 410.7 & 1611 & & 661776 & & 661776 \\
\hline 373 & AS & 392.4 & 111.5 & 33.4 & 247.5 & 241 & 5156 & 59720 & 574945 & 634666 \\
\hline 380 & LH & 505.0 & & 23.7 & 481.3 & 3064 & & 1474584 & & 1474584 \\
\hline
\end{tabular}




\begin{tabular}{|c|c|c|c|c|c|c|c|c|c|c|}
\hline No. & $\begin{array}{c}\text { Spawning } \\
\text { Phase }\end{array}$ & $\begin{array}{c}\text { Ovary } \\
\text { Mass (g) }\end{array}$ & $\begin{array}{c}\text { 'HD' } \\
\text { Mass (g) }\end{array}$ & $\begin{array}{l}\text { OW } \\
\text { Mass (g) }\end{array}$ & $\begin{array}{l}\text { 'Assorted' } \\
\text { Mass (g) }\end{array}$ & $\begin{array}{c}\text { 'Assorted' } \\
\text { Density } \\
\text { (HD/g) }\end{array}$ & $\begin{array}{c}\text { 'HD' } \\
\text { Density } \\
\text { (HD/g) }\end{array}$ & $\begin{array}{r}\text { 'Assorted' } \\
\text { No. }\end{array}$ & $\begin{array}{l}\text { 'HD' } \\
\text { No. }\end{array}$ & $\begin{array}{l}\text { Batch } \\
\text { Fecundity }\end{array}$ \\
\hline 391 & ST & 323.5 & 82.4 & 30.1 & 211.0 & 99 & 5340 & 20949 & 439987 & 460935 \\
\hline 394 & LH & 549.6 & 40.6 & 36.2 & 472.8 & 1726 & 2900 & 816162 & 117726 & 933888 \\
\hline 401 & AS & 519.0 & 41.8 & 38.9 & 438.3 & 1648 & 4454 & 722397 & 186190 & 908587 \\
\hline 455 & AS & 298.0 & 21.1 & 30.1 & 246.8 & 1063 & 4176 & 262261 & 88117 & 350377 \\
\hline 458 & LH & 303.6 & & 24.4 & 279.2 & 1247 & & 348215 & & 348215 \\
\hline 464 & EH & 365.0 & 13.8 & 25.4 & 325.8 & 2058 & 3800 & 670349 & 52442 & 722791 \\
\hline 466 & LH & 518.8 & 13.4 & 47.4 & 458.0 & 1766 & 3282 & 808864 & 43975 & 852838 \\
\hline 467 & LH & 531.6 & & 42.0 & 489.6 & 1256 & & 615099 & & 615099 \\
\hline 481 & EH & 276.9 & & 30.0 & 246.9 & 2378 & & 586986 & & 586986 \\
\hline 489 & LH & 205.1 & & 28.4 & 176.7 & 1124 & & 198608 & & 198608 \\
\hline 495 & AS & 452.0 & 118.7 & 28.7 & 304.6 & 70 & 4168 & 21347 & 494757 & 516104 \\
\hline 548 & LH & 444.9 & & 43.6 & 401.3 & 1892 & & 759241 & & 759241 \\
\hline 587 & AS & 517.7 & 39.3 & 42.0 & 436.4 & 420 & 3511 & 183277 & 138002 & 321279 \\
\hline 595 & AS & 355.7 & 104.0 & 20.6 & 231.1 & 165 & 5611 & 38191 & 583566 & 621757 \\
\hline 600 & EH & 329.6 & 85.7 & 43.5 & 200.4 & 203 & 5595 & 40593 & 479459 & 520052 \\
\hline 605 & AS & 424.4 & 63.3 & 37.5 & 323.6 & 147 & 4377 & 47695 & 277061 & 324756 \\
\hline 621 & LH & 294.0 & & 33.7 & 260.3 & 1486 & & 386761 & & 386761 \\
\hline 650 & AS & 287.0 & 67.4 & 36.3 & 183.3 & 542 & 5307 & 99267 & 357665 & 456932 \\
\hline 651 & AS & 184.5 & 10.2 & 17.1 & 157.2 & 46 & 6329 & 7232 & 64556 & 71788 \\
\hline
\end{tabular}

